\title{
Growth characteristics of basal cell carcinoma
}

Citation for published version (APA):

Verhaegh, M. E. J. M. (1998). Growth characteristics of basal cell carcinoma. [Doctoral Thesis, Maastricht University]. Datawyse / Universitaire Pers Maastricht. https://doi.org/10.26481/dis.19981216mv

Document status and date:

Published: 01/01/1998

DOI:

10.26481/dis. $19981216 \mathrm{mv}$

Document Version:

Publisher's PDF, also known as Version of record

\section{Please check the document version of this publication:}

- A submitted manuscript is the version of the article upon submission and before peer-review. There can be important differences between the submitted version and the official published version of record.

People interested in the research are advised to contact the author for the final version of the publication, or visit the DOI to the publisher's website.

- The final author version and the galley proof are versions of the publication after peer review.

- The final published version features the final layout of the paper including the volume, issue and page numbers.

Link to publication

\footnotetext{
General rights rights.

- You may freely distribute the URL identifying the publication in the public portal. please follow below link for the End User Agreement:

www.umlib.nl/taverne-license

Take down policy

If you believe that this document breaches copyright please contact us at:

repository@maastrichtuniversity.nl

providing details and we will investigate your claim.
}

Copyright and moral rights for the publications made accessible in the public portal are retained by the authors and/or other copyright owners and it is a condition of accessing publications that users recognise and abide by the legal requirements associated with these

- Users may download and print one copy of any publication from the public portal for the purpose of private study or research.

- You may not further distribute the material or use it for any profit-making activity or commercial gain

If the publication is distributed under the terms of Article $25 \mathrm{fa}$ of the Dutch Copyright Act, indicated by the "Taverne" license above, 
Growth characteristics of basal cell carcinoma 
(0) Merhaegh, Maastricht 1998

ISBN 9052782431

Vormgeving en druk: Datawyse / Universitaire Pers Maastricht 


\title{
Growth characteristics of basal cell carcinoma
}

\author{
Proefschrift
}

ter verkrijging van de graad van doctor

aan de Universiteit Maastricht,

op gezag van de Rector Magnificus,

Prof.dr. A.C. Nieuwenhuijzen Kruseman,

volgens het besluit van het College van Decanen

in het openbaar te verdedigen

op woensdag 16 december 1998 om 14.00 uur

door

Marcus Emile Johannes Maria Verhaegh

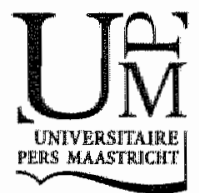




\section{Promiotortes}

Prof dr. H.A.M. Neurnann

Prof. dr. J.W. Arends

Co-promotor

Dr. Re Hockzema

Beoordelingscommissie

Prof. dr. J.J. Manni (voorzitter)

Dr. A.M. Duijvestijn

Dr. V. Noordhoek Hegt (Sint Franciscus Gasthuis, Rotterdam)

Prof. dr. F.C.S. Ramaekers

Prof. dr. B.J. Vermeer (Universiteit Leiden)

Financial support by Medi Nederland BV, Medireva, Janssen-Cilag BV, Boots Healthcare BV. Varodem, Yamanouchi Pharma BV, Roche Pharmaceuticals, Novartis Pharma BV, Leo Pharmaceutical Products BV. Smith \& Nephew Nederland BV, Glaxo Wellcome BV, Galderma, Coloplast BV, Will-Pharma, Lorex Synthélabo and Hoechst Marion Roussel BV for the publication of this thesis is gratefully acknowledged. 
"There are more thing in Heaven and Earth, Horatio, than are dreamr of in your phitosophy"

William Shakespeare

Aan mijn Ouders

Voor Jesje, mijn steun in het schijnbaar onbereikbare 


\section{Contents}

Chapter 1

General introduction 9

Chapter 2

Adhesion molecule expression in basal cell carcinoma

Chapter 3

Immunohistochemical localization of granzyme B in peritumoral infiltrates of basal cell carcinoma 47

Chapter 4

Expression of the apoptosis-suppressing protein bct- 2 in nonmelanoma skin cancer 59

Chapter 5

Transforming growth factor-beta and bcl-2 distribution patterns distinguish trichoepithelioma from basal cell carcinoma

Chapter 6

Clinical and histological features of recurrent extensive basal cell carcinoma 81

Chapter 7

Surgical margins for excision of primary and recurrent basal cell carcinoma 93

Chapter 8

General discussion and summary 107

Samenvatting $\quad 117$

Dankwoord 121

Curriculum Vitae 125

List of abbreviations $\quad 127$ 
$=$ 


\section{Chapter 1}

\section{General introduction}

\section{Introduction}

Basal cell carcinoma (BCC) is the most common type of malignancy seen today and its incidence continues ro increase. BCCs are slow growing tumors that rarely metastasize or cause death but can result in extensive morbidity through local invasion and tissue destruction. The cell of origin is probably an epidermal pluripotent stem cell, and there is a range of histologic subtypes, including nodular, superficial and infiltrating. Most BCCs are managed by simple excision, cryosurgery, curettage and electrodesiccation, and radiation therapy, but some primary and recurrent carcinomas present a more difficult challenge. Mohs" micrographic surgery (MMS) is the most accurate method of removing these skin cancers and achieving the highest cure rates.

History

BCC has left evidence of its existence ever since 4000 years ago. By examining mummified skeletons from the Dynastic period in Asyut, an Egyptian city on the left bank of the Nile, Satinoff and Wells found bony manifestations (including jaw cysts, syndactyly, polydactyly and bifid ribs) related to the nevoid basal cell carcinoma syndrome. ${ }^{1}$

Despite the antiquity of the lesions, nosologic description of $\mathrm{BCC}$ is far more recent. The term noli-me-tangree is said to be identified with $\mathrm{BCC}^{2}$ It derives from the Latin, literally "I do not wish that I touch" or, more prosaically, "touch-menot". The Latin is found in the Vulgate Bible, John 20:17, "dicit ei lesus, noli me tangere, nondum enim ascendi ad Patrem meum" (translation: "Jesus said to them, "Do not touch me, for II have not yet ascended to the Father"). ${ }^{3}$

In the 14th century, the great French surgeon, Guy de Chauliac (circa 1300 to 1368), attendant to popes and kings, referred to ulcerated chancres of the face as "commonly called noli me tangere" and recommended a variety of topical remedies including honey, which has ancibacterial properties. ${ }^{4}$

Jacques Daviel (1696 to 1762), the oculist of Louis XV, wrote in 1754 a treatise on the surgical trearment of noli-me-tangere, in particular of the eyelids, nose, angle of 
the eye, and adjacent tissue. He made radical excisions for the rime, often leaving the patient disfigured but functioning. ${ }^{5}$

Daviel's work was followed in France by a young doctor's thesis in 1806; Researches on the cancer of the skin of the face, called by the Ancients Noli-me-tangere. The author, P.J.L. Bouchet, argued that facial skin cancers were the least dangerous of all skin cancers, that they were usually a primary lesion, that when removed they rarely returned, and that if untreated they would slowly continue to grow. ${ }^{6}$ In 1827, Arthur Jacob, member of the royal college of surgeons in Ireland, described an ulcer of peculiar character, which attacks the eye-lids and other parts of the face. He tried ointments containing mercury, lead, zinc, copper, arsenic, sulphur, tar, cicuta, opium, belladonna, nitrate of silver and acids, withour arresting for a moment the progress of the disease. He concluded, the sooner it is completely expired by the knife, the better chance is afforded the patient of relief from a most distressing and fatal malady.?

Many authors followed Jacob in producing clinical descriptions of BCC. In 1902, E. Krompecher clearly delineated this tumor from other epithelial tumors. ${ }^{8}$ Many synonyms have been used for this rumor, e.g. Jacob's ulcer, Krompecher's tumor, rodent ulcer, adnexal carcinoma, carcinoid of the skin, basalioma, basal cell epithelioma, non-cornifying epithelioma and basal cell carcinoma.

\section{Pathogenesis}

BCCs almost never occur on mucosal or palmar/plantar surfaces. ${ }^{9-11}$ This observation has led to the suggestion that BCCs develop only in epiderm is in which pilosebaceous units are present. Several epidemiologic studies have found that the

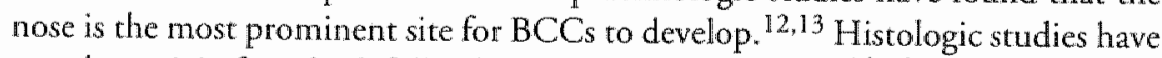
noted an origin from borb follicular and interfollicular sites. ${ }^{14-16}$ Recent immunocytochemical work noted identical keratin profiles in BCCs and the outer root sheath of hair follicles, suggesting some etiologic connection. ${ }^{17}$

$B C C$ is a neoplasm composed of usually undifferentiated yet quite pluripotent cells, and this suggests a possible etiologic relationship with stem cells. ${ }^{18,19}$ The cutaneous carcinogenesis process usually is thought to involve the mulristeps of initiation, promotion, and conversion. ${ }^{20}$ However, in BCC development, there is no clinically evident "promotion" stage. It seems that BCCs appear to arise de nowo and not from any precursor lesion.

$\mathrm{BCC}$ has become significantly more common in recent years. An important cause of this increasing incidence is presumed to result from increased ultraviolet (UV) radiation exposure. 
Increased BCC incidence is seen in Caucasian individuals with fair skin, poor tanning ability, blond hair, blue eyes, and male sex, and incidence increases with increasing age and significant lifetime exposure. ${ }^{21-24}$

Over $80 \%$ of turnors occur on the head and neck, the areas of greatest sun exposure. However, up to $33 \%$ of BCCs on the head and neck occur in areas with minimal sun exposure. ${ }^{25,26}$ Therefore causative factors other than UV-radiation have to be considered, like ionizing radiation, chemical carcinogens and possibly infection with human papillomaviruses. ${ }^{27}$ Moteover, superficial BCCs differ from other subtypes of BCC by occurring more commonly on the trunk and in younger patients. ${ }^{27,28}$ The differences in the age and body site distriburion berween superficial BCC and the other subtypes of BCC may indicate that they vary in their causal relationship to sunlight. The development of superficial BCC may be more strongly related to intermittent sunlight exposure, whereas the orher subrypes of BCC may be related more strongly to cumularive sunlight exposure.

$\mathrm{BCC}$ metastasizes very rarely $(0.0028 \%-0.55 \%),{ }^{29}$ There usually is a long interval between diagnosis of $\mathrm{BCC}$ and metastasis, averaging 9 years. Once metastatic disease is diagnosed, survival is brief, averaging 8 months. No characteristics predictive of metastasis have been nored. ${ }^{29}$ Why BCC merastasizes so rarely is unknown. The most common theory is that BCC is a "stromal-dependent" tumor; in the absence of its stromal component, growth of the malignant cells does not continue. $^{30,31}$

\section{Molecular genetics}

Neoplastic transformation of human cells is believed to result from a series of genetic alterations that lead to progressive disorder of growth and differentiation. This multistep process involves activation of oncogenes and/or inactivation of tumor suppressor genes. ${ }^{32}$ There are only a few studies showing oncogene activarion in BCCs. The fos oncogene shows high expression in some infiltrarive BCCs but low expression in well-circumscribed BCCs. ${ }^{33,34}$ Several investigators have shown $\mathrm{H}$-ras and $\mathrm{K}$-ras point mutations in a small fraction of BCCs. ${ }^{35-37}$

These data are suggestive that oncogene activation may play only a secondary role in $B C C$ pathogenesis.

$B C$-2, an oncogene that protects cells from programmed cell death, is expressed at high levels in $\mathrm{BCC}$, but rearrangements of the gene have not been demonstrated in this tumor. ${ }^{38}$

Tumor suppressor genes normally exert a negative controll on cell growth. Inactivation of both homologues ("wo hits") is required for a growth-promoring effect. $p 53$ is a tumor suppressor gene that plays a role in carcinogenesis in a wide variety of tissues. ${ }^{39}$ The observed loss of heterozygosity for alleles on chromosome $17 \mathrm{p}$ in 
BCCs was presumed to be related to inactivation of $p 53$. Direct sequencing of the p.53 gene revealed mutarion of at least one allele in approximately $50 \%$ of BCCs. $40-42$ Until now, no relarionship berween $p 53$ mutation and tumor size, hisrology, or recurrence; has been identified.

Constitutional tumor suppressor gene mutations underlie a large number of hereditary cancer predisposition syndromes ${ }^{32}$, and key evidence that BCCs may arise through inactivation of a tumor suppressor gene came from studies of hereditary predisposition to $\mathrm{BCCs}$. Approximately $0.5 \%$ of $\mathrm{BCC}$ cases are atributable to the nevoid basal cell carcinoma syndrome (NBCCS), ${ }^{43}$ an autosomal dominant disorder characterized by multiple BCCs, keratocysts of the jaw, and pits of palms and soles. ${ }^{4}$ On the basis of the clinical behaviour of these BCCs, several investigators have suggested that NBCCS fits a two-hit model; ${ }^{45-47}$ i.e., tumors develop in cells sustaining two genetic alterations. The first alteration or hit is the inheritance of a mutation in a tumor suppressor gene, and the second hit is inactivation of the normal homologue by environmental mutagenesis or random genetic rearrangement. Sporadic BCCs would arise in cells that underwent two somatic events resulting in inactivation of the NBCCS gene.

Tumor deletion and gene mapping data support the hypothesis that NBCCS is caused by mutation in a tumor suppressor gene on chromosome 9 (allelic loss for chromosome $9 \mathrm{q} 22$ ). ${ }^{48}$

A human sequence (PTCH) with strong homology to the Drosophilia segment polarity gene, patched, was isolated from the NBCCS region and shown to be expressed in many of the tissues affected in NBCCS patients. ${ }^{49-51}$ The Drosophilia version of patched is a cell surface molecule that may be involved in cell-cell communication. In addition, patched is known to suppress the expression of various growth factors.

Most likely the NBCCS gene is a "gatekeeper", the loss of which is needed to start the process of carcinogenesis; 52.53 and $p 53$ mutations possibly contribute to the malignant characteristics of tumors.

\section{Biologic characteristics}

Factors that influence the rates of cell division and apoptosis rogether determine the growth rate of BCC. BCCs are typically slow growing tumors, often taking months to years before reaching significant proportions. ${ }^{54}$ Studying tumor cell proliferation by means of in vivo injecrion of $3 \mathrm{H}$-rhymidine in patients with BCCs, Weinstein and Frost calculated the BCC tumor cell cycle to be 217 hours, or a tumor doubling time of only a few weeks. ${ }^{55}$ Such a relatively rapid growth rate is at odds with the clinically observed, characreristically slow BCC doubling time of months to years. BCC tumors have been estimated to grow at a rate of berween 
$1 \mathrm{~mm}$ and $6 \mathrm{~mm}$ annually. $56-58$ More recently, however. Terz and coworkers, using in wiwo BCC labelling techniques, demonstrated that between $5 \%$ and $40 \%$ of tumor cells were arrested for variable rime periods in the $\mathrm{G} 2$ or $\mathrm{GO}$ phases of the cell cycle. ${ }^{59}$ They contended that such a large compartment could account for the observed slow growth rates of these tumors. Heenan and Galand later reported a tumoral prolongarion of the S (DNA synthesis) phase of the cell cyde, an effect which could also contribute to the observed slow growth rates of BCCs. ${ }^{60}$ Finally, supporting the notion that a BCC typically grows slowly, because a large percentage of its cells proliferate either slow or not at all, Grimwood et al. using $3 \mathrm{H}$ - thymidine in the nude mouse model, found that labelled material was primarily taken up by those cells located at the periphery of a BCC nodule rather than by those located more centrally. 61 In mote aggressive histologic subrypes,

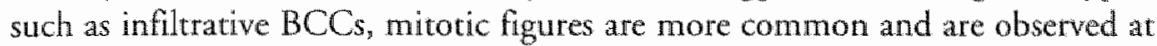
random throughout the tumor islands. ${ }^{62,63}$

Because tumor growth is the net result of proliferation versus cellular degeneration, induction of cell degeneration could also be an important feature contributing to the slow growth of BCC. In indolent BCC subtypes, growth rates may be partially determined by apoptosis, a programmed form of cell death that can regulate cell populations, while in aggressive types of $B C C$, apoptosis may be inhibited. ${ }^{64,65}$

The protein product of the oncogene $b c b-2$ has been shown to inhibit apoptosis. ${ }^{66}$ In a recent study in which bol-2 protein expression was used as an indicator of apoptotic inhibition and in which immunocytochemical techniques were used, BCCs stained strongly for the presence of bot 2.65

\section{Cellullar immunology}

The mechanisms of anti tumor-immune response are rather complex and are as yer neither fully elucidated nor understood. However, several subpopulations of I cells, cells of the monocyte-macrophage limeage, natural killer (NK) cells, B cells producing specific and natural cytotoxic antibodies have been implicated in the host's anti-tumor immune response.

The role of the immune system in controlling BCC development and growth is still under debate.

Systemic immunity: The incidence of nonmelanoma skin cancer increases with age. Decreasing systemic immune function and increased exposure to carcinogenic agents, especially UV light, may play a role. Depression of cell-mediared immuniry begins at puberty and becomes most pronounced after the age of 50 years. 67 
The immunosuppressed starus of patients appears to play only a modest role in increasing BCC incidence. Several studies of renal transplantant populations and chronic PUVA users have noted an increase in curancous SCC incidence in these immunosuppressed patients of 20 to 30 times the incidence compared to the normal population. ${ }^{68-70}$ However, increases in BCC incidence in these studies were much more modest, ranging from 1.4 to 5 times the normal incidence. The clinical behaviour of BCCs in immunosuppressed patients does not appear to be significantly more aggressive than in normal popularions.

Immunological studies in patients with BCC have demonstrated several abnormalities. Dellon et al observed an absence of infiltrate and a low T-cell level in the peripheral blood of parients with BCCs of large size ( $2 \mathrm{~cm}$ in diameter) and aggressive growth partern. ${ }^{71,72}$ Two other groups, however, found normal $T$ cell levels in 80 patients with $B C C s$, al though in a small subset of patients with metarypical BCC tumors, levels were depressed. 73,74

Local immunity: Only around one third of BCCs which are excised with histologically proven positive surgical margins are estimated to recur. ${ }^{75}$ In addition, spontaneous partial regression is not an uncommon phenomenon in BCC. Curson et all noticed active regression zones in $14 \%$ of investigated $\mathrm{BCCs}{ }^{76}$ Immune-mediated effects may be involved in boch of these phenomena. Hunt et al, suggested that activated CD4+ cytokine-secteting cells are important in the regression of BCCs. ${ }^{77}$

BCCs are frequently (about 60\%) associated with a peritumoral mononuclear infiltrate. Until now, the function of this inflammatory infiltrate and its possible role in the control of tumor growth is unclear. Typically, inflammatory cells are most dense at the lateral and inferior borders of the tumor, without touching or infiltrating the BCC tumor lobules. ${ }^{78}$ The infiltrate consists primarily of T lymphocytes with a predominance of the CD4+/T-helper over the CD8+/T-cytotoxic subser, similar to that found in typical delayed hypersensitivity reactions. ${ }^{78-80}$ Natural killer cells, considered to be the first nonspecific line of defence against tumors, and B-cells are seen in much lower numbers.

Besides identifying the immunoregulatory subsets of lymphocytes, the functional activation status also is of considerable importance. Different stages of lymphocyte activation are characterized by the appearance of specific cell surface antigens. Inrerleukin 2 receptor (IL2R) is expressed during the early stages of activation. ${ }^{21}$ Transferrin receptor expression by lymphocytes occurs later than IL2R, approximately 48 hours after activation. ${ }^{82}$ The class II major histocompatibility complex molecule human lymphocyte antigen (HLA)-DR appears tate ar between 5 and 7 days. ${ }^{82}$ The expression of the antigen recognized by the antibody OKT10 occurs intermediate in time berween that of the transferrin receptor and HLA-DR. 82,83 Markey et al demonstrated expression of activation antigens in six BCCs. The class II molecule HLA-DR was expressed by $58 \%$ of the infillrate, with fewer lym- 
phocytes variably staining for IL2R (13\%), transferrin receptor $(16 \%)$, and OKT $10(22 \%){ }^{84,85}$

The presence of an activated infiltrate around BCCs has been suggested to explain in pare the slow growth of this tumor. However, similar findings of HLA-DR, transferrin receptor, and IL.2R expression are demonstrated also in benign and premalignant tumors. Furthermore, the lack of qualitative or quantitative differences in the infiltrates accompanying divergent tumors suggests that the activated infiltrate alone does not seriously affect the biologic behavior of the tumor.

The fact that also a considerable number of OKT $10+\mathrm{T}$ cells were observed in the peritumoral infiltrate around BCCs, possibly is of more importance. Especially because this subset of activated $T$ cells is typically found in the presence of malignant skin tumors but not in inflammatory dermatoses. ${ }^{84,86}$

Finally, a selective expression of specific $\alpha \beta \mathrm{T}$-cell receptors by BCC peritumoral $\mathrm{T}$ cells is demonstrated. ${ }^{87} \mathrm{~T}$ cells with $\alpha \beta \mathrm{T}$-cell receptors recognize antigens and are responsible for a specific immune respons.

In order to control the proliferation of the tumor by the surrounding cellular infiltrate, expression of adhesion molecules on tumor cells is required. The expression of class I major histocompatibility complex (MHC) antigens by BCC tumor cells is decreased compared with normal skin, and class II antigens are not expressed by BCC tumor cells at all. ${ }^{88-91}$ Regarding adhesion molecule expression in immunetumor cell interactions, lymphocyte function associated antigens LFA-1 and LFA-2 are expressed on T' lymphocytes, and these interact with their complementary ligands locared on tumor cell surfaces, intercellular adhesion molecule-1 (ICAM-1) and the widely distributed surface molecule LFA-3, respectivily. ${ }^{92}$ Several studies demonstrated that ICAM-1 and LFA-3 are nor expressed by BCC tumor cells at all. ${ }^{90,93}$

The lack of constitutive ICAM-1 expression supports the contention of others that BCCs are less immunogenic than other cutaneous tumors because adhesion mollecules are essential to cytotoxic killing functions. ${ }^{73,74}$

The inability of $\mathrm{BCC}$ tumor cells to express adhesion molecules is not absolute. Taylor et al presented a study where they demonstrated induction of ICAM-1 expression on tumor cells after BCC tissue had been incubated in vitro wich IFN- $\gamma^{94}$ Interestingly, tumor cells exposed to IFN- $\alpha$ remained negative for ICAM-1 and LFA-3.

\section{Clinical presentation}

A typical $\mathrm{BCC}$ has distinctive morphologic features that make it readily recognizable. A pearly, teleangiectatic papule occurring on the cheek of an elderly Cauca sian man presents no significant diagnostic dilemma. Yet, the presentations of 
BCC are as varied as the tumor is common. For example, a superficial BCC is characterized by a red, slightly scaling, well-demarcated ectematous-appearing patch with a thread-like pearly rolled border. The morpheaform BCC is an atrophic, white, somerimes slightly eroded or crusted plaque that often looks like a scar.

$B C C$ is the most common malignant tumor in humans, and skin cancers currently constitute approximately one third of all diagnosed cancers. The incidence of $\mathrm{BCC}$ is increasing worldwide, likely under the influence of sunbarhing behaviour, aging and a decrease in stratospheric ozone.

The reported incidence of $\mathrm{BCC}$ in Caucasians in the United States ranges from 185 to 422 cases per 100.000 population. ${ }^{95}$ According to the Skin Cancer Foundation, one in six Americans will develop non-melanoma skin cancer (NMSC) during his or her lifetime. Although less data exist for African-Americans, one reported figure is 3.4 per $100.0000^{96}$ In Australia, incidence figures between 672-760 per 100.000 are reported. ${ }^{97,98}$ In the Netherlands (15 million inhabitants), approximately $18.000 \mathrm{BCC}$ (incidence of 120 per 100.000 ) were diagnosed in 1994, with an expected increase of $2.700 \mathrm{BCCs}$ yearly. ${ }^{99}$

Important $\mathrm{BCC}$ demographic variables include age, gender, degree of pigmentation, history of previous BCC, associated skin lesions, history of previous trauma, and general medical history.

BCC becomes increasingly common with age, with an average age somewhat older than $60 .{ }^{100}$ However, BCC has been documented in several collected series in patients younger than age $20 .^{101-103}$

Most studies show BCC to be more common in men. However, some recent work in younger populations suggests that this trend may be reversing, probably related to changing habits among young women. ${ }^{104,105}$

Intrinsic pigmentation is clearly one of the best predictive risk factors for BCC. It is estimated that BCC accounts for no more than $8 \%$ of all skin cancers in African-Americans, this in contrast with Caucasians in which approximately $70 \%$ of all skin cancers are BCCs. ${ }^{106,107}$

Ir is not uncommon for patients to present with more than one $\mathrm{BCC}$ tumor. One study reported that the incidence of multiple, coexisting tumors was $13 \%{ }^{108}$ Robinson performed a 5-year prospective study of $1000 \mathrm{BCC}$ patients; $36 \%$ developed a second $\mathrm{BCC}$ and $15 \%$ developed a third rumor in the same time period. ${ }^{109}$ Other studies calculated for individuals with at least one non-melanoma skin cancer an esrimated risk of $17 \%$ within 1 year, $35 \%$ within 3 years, and $50 \%$ within 5 years to dewelop an additional nonmelanoma skin cancer. ${ }^{110-112}$ BCCs have been reported to develop in traumatic settings, the scars of lupus vulgaris, chronic stasis ulcers, lesions of epidermolysis bullosa, epidermal inclusion cysts, hemangiomas, pilomatricomas, porokeratoses, and nevi flammeus. ${ }^{113-118}$ Some of these associations may be random. In some cases, however, the associa- 
tion berween a skin lesion and $\mathrm{BCC}$ is not at random. The risk of $\mathrm{BCC}$ development is clearly increased in persons with dermatofibroma, nevus sebaceus and linear unilateral basal cell nevus. BCC-like changes occur in $2 \%$ to $8 \%$ of dermatofibromas. ${ }^{119}$ The neoplasric potential of these basaloid proliferations overly. ing dermatofibromas was once doubred. However, recent data using antikerarin antibodies, $\beta 2$ microglobulin and bol-2 studies, have demonstrated that the BCC-like basaloid changes are immunohistochemically identical to sporadic BCCs. ${ }^{120-122}$ BCCs have been reported to originate in $5 \%$ to $20 \%$ of sebaceous nevi. ${ }^{123,124}$ Both dermatofibromas and nevus sebaceus are characterized by onset of BCCs in young pacients. Linear unilateral basal cell nevus is a very rare, nongenetic disorder first described by Carney in $1952 .{ }^{125}$ Clinically, it presents as an extensive, unilateral, linear or zosteriform eruption of BCCs, usually at birth. ${ }^{126}$ $\mathrm{BCCs}$ are also clearly associared with several genodermatoses, including the nevoid basal cell carcinoma syndrome, Bazex's syndrome, Rombo syndrome, albinism, and xeroderma pigmentosum. ${ }^{127-129}$

Finally, $\mathrm{BCC}$ has a well known association with previous ionizing radiation and inorganic arsenic. ${ }^{130,131}$

\section{Histology}

BCC is recognized histologically by the presence of multiple islands, nests, or cords of basaloid tumor cells with peripheral palisading of nuclei and variable tumor-stromal separation artifact. The tumor generally arises from the overlying epidermis or adjacent follicular epithelium. The basaloid tumor cells have uniform, round to oval, slightly hyperchromatic nuclei, coarsly clumped chromatin and scant cytoplasm. Nucleoli are inconspicious and mitoses are variable. The surrounding stroma is characteristically mucinous, with a variable fibroblastic and inflammatory component. 132,133

A wide variety of $\mathrm{BCC}$ histopathologic subrypes have been described. ${ }^{134}$ Many are purely descriptive and have not been shown to affect growth rate. This is particularly true of those tumors differentiating toward appendageal structures.

Lang and Maize were the first to clearly define five BCC subtypes with important clinical implications; ${ }^{135}$ superficial, nodular, micronodular, infiltrating, and morpheaform. They also described the frequent overlap of histologic patterns within a given tumor, i.e., the mixed-type (Fig. 1).

Superficial BCC has also been termed superficial multifocal, superficial multicentric, or superficial spreading $\mathrm{BCC}$. This type accounts for approximately $10 \%$ of all BCCs. ${ }^{136}$ Histologically, it is characterized by multiple small buds of basaloid tumor cells that arise from the epidermis and extend into the superficial dermis. All nests are in continuity with the epidermis, although occasionally there is arti- 


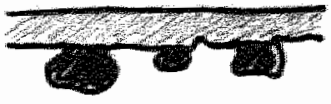

superficial

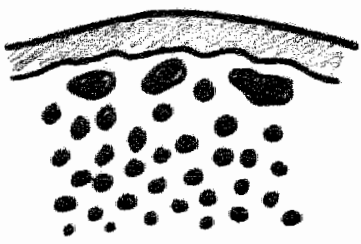

micronodular

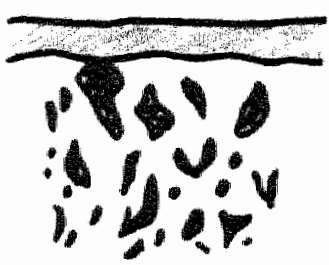

infiltrative

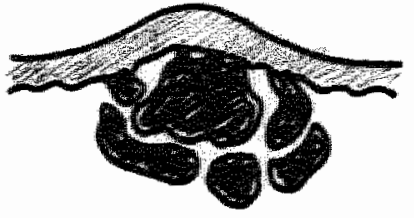

nodular

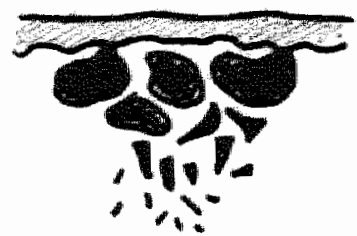

mixed-type

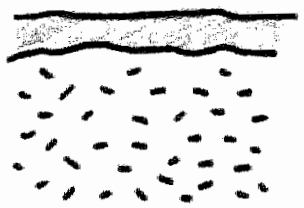

morphoea-like

Figure 1. Growth patterns of BCCS.

factual separation resulting from the plane of a cut. When tumor nests have no connection with the epidermis, the BCC should nor be classified as superficial $B C C$. Superficial BCC is unique in that its lateral margins are notoriously difficult to delineate histologically. In three-dimensional reconstructions, the tumor buds have been shown to form anastomosing or interconnecting complexes. ${ }^{137}$ In twodimensional histologic sections, however, they often appear as multiple, small, independent rumors, separated by skipped areas of involvement. ${ }^{138}$ Therefore, the pathologist may erroneously inform the clinician that the lesion has been removed completely because the lateral borders appear to be tumor-free, when, in fact, the lateral borders represent the skipped areas.

Nodular BCC, also known as solid, macronodular, or well circumscribed BCC, is the most frequent architectural pattern encountered, accounting for $50 \%$ to $70 \%$ of cases. ${ }^{133,136}$ Nodular BCCs show features that have been considered classic for 
BCC, including well circumscribed, large rounded islands of tumor cells with a smooth, palisaded peripheral border and stromal retraction. Larger or longstanding lesions that ulcerate are termed nodulo-ulceratiwe. There may be an "adenoidal" pattern of the large tumor islands or central cumor necrosis leading to the cystic changes described in some tumors. ${ }^{132,133}$

Micronodular BCC is similar to nodular BCC except that the tumor nests are predominantly small and rounded. These smaller tumor islands often approximate the size of hair bulbs. ${ }^{139.140}$ The peripheral palisading may not be as well developed as in nodular BCC and the stroma is often more collagenous, rather than myxoid. The micronodular variant is characterized by significant subclinical extensions, and an infiltrate-pattern widely through the dermis or subcutis.

Morpheaform or sclerosing BCC shows thick, scarlike collagen (sclerosis) in the surrounding dermis, with the tumor cells appearing to "force their way" through this dense connective tissue.

Infiltrating BCCs have tumor islands of small but wariable size. The border of the islands is not smooth; it has irregular, spiking, or jagged projections. Some islands extend out into a single-cell pattern, much like a morpheaform BCC but without the sclerosis. Stromal retraction is often not present. Most infiltrative BCCs are characterized by a variable nodular component in the superficial part of the lesion, but the infiltrative portion constitutes the majority of the tumor. Together, the morpheaform and infiltrating BCCs, account for approximately $10 \%$ to $15 \%$ of all BCCs.

It appears that morpheaform and infiltrating patterns are most aggressive (i.e. an infiltrative rather than an expansile pattern of growth), the nodular and superficial are the least aggressive, and the micronodular pattern occupies a place somewhere in between.

Many tumors have a mixed rumor type, i.e., two or more histologic subtypes represented in the same rumor. In one study, such a mixed pattern was seen in $38.5 \%$ of the cases. ${ }^{139}$ In these tumors, clinical behaviour reflects the most aggressive subtype found within the tumor. Often the most aggressive pattern is present at the base of a mumor and may be missed if a superficial biopsy is taken. ${ }^{139}$ There are many other histologic subtypes of BCC. They often further define a particular lesion, by describing the pattern or direction of differentiation, e.g., toward an adnexal structure, or by noting specific cytologic features. To date, there are no data suggesting that these variants affect prognosis in any way, with the possible exception of basosquamous carcinoma. The existence of this last lesion as a subtype of $B C C$ or as a transitional form between $B C C$ and squamous cell carcinoma ( $S \mathrm{CC}$ ) is controversial and has been horly debated. ${ }^{141,142}$ The criteria used to define basosquamous carcinoma wary widely in the literature. Those lesions that have a distinct admixture of conventional BCC and classic SCC may be classified as basosquamous carcinoma. The term "metatypical BCC" has also been applied to tu- 
mors with a mixed basaloid and squamous histology and, thus, is often used interchangeably with basosquamous carcinoma. The reported incidence of basosquamous BCC type is $2 \%$ to $3 \%, 141,143$ but differentiating basosquamous carcinoma from keratotic BCC, BCC with squamous metaplasia, and "collision" tumors may be quite problematic, resulting in an overdiagnosis of basosquamous carcinoma. Nevertheless, the concept of a cutaneous neoplasm that represents a continuum between BCC and SCC is an important one, since the literature and also our own experience suggests that basosquamous carcinoma may behave in a more aggressive fashion than conventional BCC, with a higher rate of local recurrence and metastasis. ${ }^{132,141,143,144}$

Some other histologic subtypes are: adenoid BCC (an adenoid pattern is seen in $1 \%$ to $7 \%$ of $\mathrm{BCCs}$, especially in association with nodular $\mathrm{BCC}),{ }^{136}$ pigmented $\mathrm{BCC}$ (pigmentation is present in $6 \%$ to $7 \%$ of $\mathrm{BCCs}$ ), ${ }^{136,145}$ fibroepithelioma of Pinkus (characterized by multiple, long, thin, anastomosing strands of basaloid cells), ${ }^{146} \mathrm{BCC}$ with follicular differentiation (keratotic $\mathrm{BCC}$ and infundibulocystic BCC), ${ }^{147} \mathrm{BCC}$ with sebaceous differentiation (sebaceous epithelioma), BCC with apocrine differentiation, BCC with eccrine differentiation (this type of tumor must be distinguished from eccrine carcinoma, adenoid cystic carcinoma, and microcystic adnexal carcinoma), adamantinoid $\mathrm{BCC}$, granular cell $\mathrm{BCC}$, pleomorphic $\mathrm{BCC}$, clear cell $\mathrm{BCC}$, signet-ring $\mathrm{BCC}$ and $\mathrm{BCC}$ with neuroendocrine differentiation.

Finally, there are many cutaneous neoplasms that may histologically simulate BCC. Some selecred histologic simulants are: trichoepithelioma, desmoplastic trichoepithelioma, basaloid follicular hamartoma, folliculocentric basaloid proliferation, microcystic adnexal carcinoma, peripheral ameloblastoma, and cloacogenic carcinoma.

\section{Features associated with recurrence}

Although most BCCs are cured by inirial treatment, incomplete removal will result in tumor persistance, which may further result in continued tumor growth (approximately 33\%), often with substantial morbidity, and occasionally, mortality. ${ }^{148.150}$ Most $\mathrm{BCCs}$ that recur do so within 3 years of treatment. ${ }^{151}$ However, some BCCs recur many years later. Rowe et al combined recurrence statistics from several studies and concluded that $30 \%$ of recurrent BCCs recurred in the first year after treatment, $20 \%$ in the second year, $16 \%$ in the third year, $8 \%$ in the fourtl year, $8 \%$ in the fifth year, and $18 \%$ of BCC recurrences occurred 6 to 10 years after treatment. ${ }^{152}$

Perhaps tumor dormancy and/or decreases of peripheral T-cell levels may play a role in the timing of $B C C$ tumor cell proliferation. ${ }^{153}$ The type of surgical closure 
may also influence the time it takes for a $B C C$ recurrence to become manifest. In a study by Richmond et al, most recurrent BCCs appeared by the end of the first two years after surgery if the wound was closed by a split thickness skin graft or a full thickness skin graft, and by the end of the fourth year if closed by a skin Aap. ${ }^{154}$

The important variables in a primary $\mathrm{BCC}$ influencing whether the tumor will recur after treatment include anatomic location, histologic subrype, size, and previous treatment. ${ }^{155-157}$

The anatomic sites known to be more difficult to eradicate the tumor complerely include; the scalp, ears, eyes, nose including the paranasal areas, mouth, nasal vestibule, auditory meatus, and rectum. ${ }^{157-159}$ In addition, the so-called "embryonic fusion" planes, located in such areas as the preauricular and postauricular sulci, the paranasal regions, and the inner canthi, allow deep extensions of BCCs because of the presence of noncontinuous and nonuniform subcutaneous tissues. ${ }^{156,160,161}$ Infiltrative/morpheaform BCC is often the subtype of BCC found in siruations of recurrence, ${ }^{160,162,163}$ it is also the histologic subtype most prone to recur after treatment, ${ }^{164,165}$ and the one most prone to be associated with disease-positive surgical margins and incomplete excision. ${ }^{166}$

Latge $\mathrm{BCCs}(>2 \mathrm{~cm})$ are more difficult to cure than small BCCs. ${ }^{167,168}$ Large BCCs have, by definition, been aliowed to progress and have therefore had the opportunity to grow deeply and peripherally. ${ }^{169,170}$

Multiply recurrent BCCs have high recurrence rates regardless of the anatomic site or treatment modality used. ${ }^{159,171}$

\section{Principles of management of BCC}

There are a number of options available to the physician for the management of BCC. The most commonly used treatment modalities are surgical excision including Mohs' micrographic surgery (MMS), cryosurgery, radiation therapy, curettage and electrodesiccation. Before undertaking one of these treatments, however, it is important to assess patient and tumor individually, so that the most appropriate therapeutic option may be selected. The patient's age, sex, health, skin color, and degree of sun damage, the tumor's location, size, histologic subtype, and hiscory of previous treatment must all be considered in derermining the optimal therapeutic modality. In addition, potential complications, cosmesis, costs, and most importantly, recurrence rates for each approach must be evaluated with respect to each individual patient.

The role of each mode of therapy is summarized in Table $\mathrm{I}$, based on principal indications, advantages, disadvantages, and recurrence rate. ${ }^{172-1 \% 6}$ 
Only MMS will be discussed in further detail because this procedure is less widely used in the Netherlands and consequently less known.

It all started when Frederic E. Molis was a Brittingham Research Assistant to Professor Michael F. Guyer, geneticist and chairman of the Department of Zoology at the University of Wisconsin in the early 1930s. While conducting experiments with warious injectable irritants to study the inflammatory response in transplantable rat cancers in normal tissue, they noticed that $20 \%$ zinc chloride solution caused tissue necrosis. They also happened to notice that microscopic examination showed well preserved structure of the cells and tissue, the same as if the tissue had been excised and immersed in a fixative solution. Dr. Mohs stated "this observation of in situ fixation might have been unrecorded and forgotten if it had not suggested the idea that it might be the basis for a method by which cancers could be excised under complete microscopic control." Skin cancers seemed most amenable to this approach. While he pondered this concept, he realized that vertically cut sections of excised tissue would not be practical because of the large number of secrions needed. He also realized that step sections would leave unexamined gaps inbetween. Finally, he concerved of the idea of excising the tissues layer by layer and microscopically examining the entire undersurface of each layer.

Then, Dr.Mohs designed a paste vehicle for zinc chloride which made accurate control of depth fixation possible. The advantages of zinc chloride included good in-situ fixation, good penetration, lack of damage to the healing qualities of the underlying tissues, lack of systemic toxicity, safety in handling, and lack of any rendency to increased metastasis.

To Dr. Mohs it seemed logical that an inerr granular material would be important as a base to permit the zinc chloricle solution to percolate down between the partides like water permeates through sand. However a binder would be necessary to prevent the solution from setting to the bottom of the container. He visited an old-fashioned pharmacy where the 85 year old proprietor introduced him to a black granular antimony or stibnite, and a number of plant excracts indluding blood root powder Sanguinaria Canadensis. The stibnire was a good granular matrix and the Sanguinaria Canadensis was an adequate binder. The pharmacist's paste was too soft so afrer many trials, Dr.Mohs settled upon a 4:1 portion of stibnite and Sanguinaria Canadensis. The solution ended up as stibnite 40 grams, Sanguinaria Canadensis 10 grams and zinc chloride saturated solution $34.5 \mathrm{ml}$. This solution was original enough to be patented and Dr. Mohs signed over all rights to the patent to the Wisconsin Alumni Research Foundation for $\$ 1$. The complerion of the development of the paste was in 1936 and at this time the term "chemosurgery" was coined by Dr. Mohs. In 1941 Dr. Mohs published his first three papers on this new technique. 

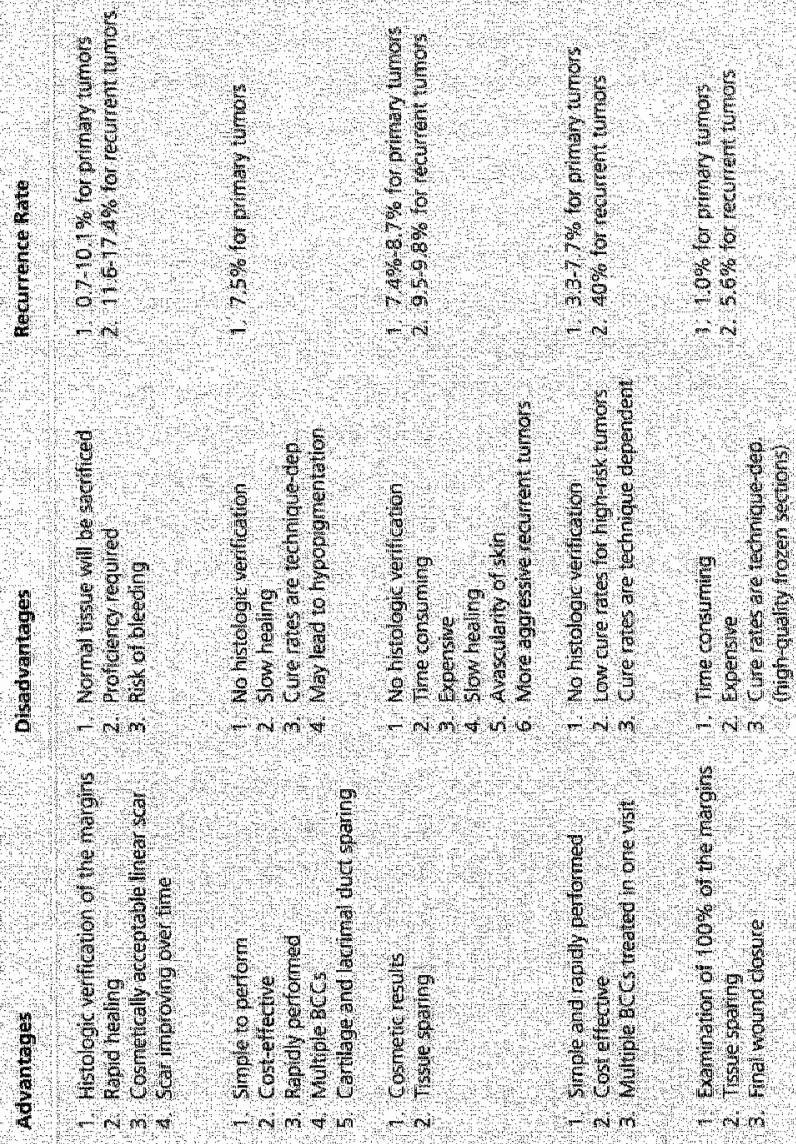
The fresh-tissue technique was first published in Dr. Mohs' chapter in Epsteins first edition of Skin Surgery in 1956 and in ten articles during the following ten years. Dr. Mohs modified the traditional fixed-rissue technique by abandoning the use of zinc chloride paste, and excised fresh tissue under local anesthesia with immediate checking of the horizontal frozen sections. At the 1969 meeting of the American College of Chemosurgery, Dr. Mohs reported the use of the fresh-tissue technique for $66 \mathrm{BCC}$ and for SCCs of the eyelid with cure rates of $100 \%$. However it was not until december of 1970 when Dr. Theodore Tromovitch presented a series of 75 parients treated with the fresh-tissue technique, that the technique began to become popular. The fixed-tissue technique has been largely replaced by the fresh-tissue rechnique over the last 25 years because of several distinct advantages; 1) less pain, 2) greater efficiency, as there is no need to wait for the zinc chloride paste to fix the tissue, 3) less time consuming, as multiple stages can be performed during the same day, 4) increased healing time, as the frozen-tissue technique allows immediate repair of the wound after tumor-free margins are obtained.

In 1967 the American College of Chemosurgery was formed, consisting mostly of Dermatologists. From the 1950 s to the 1970 s training was informal, lasting from several days to several months. In the 1980s fellowships were formalized to one or two years. In 1986 the American College of Chemosurgery officially changed its name to the American College of Mohs' Micrographic Surgery and Cutaneous Oncology. In June 1990, under the direction of Marthew H.Goodman, then full-time Director of Dermatologic Surgery at the University of California, the American Sociery for Mohs' Surgery was formed. On April 6 th 1990 the European Sociery of Micrographic Surgery was founded in Estoril, Portugal.

MMS offers the highest cure rates, while maximizing the preservation of normal tissue to simplify reconstruction of the defecr. The key difference berween MMS and conventional excision lies partly in the surgical technique but mainly in the oriantation and histologic visualization of the margins of the specimen. If the margins of specimens are assessed in routinely processed frozen or paraffin sections, the edges generally are examined by means of vertical sections through representative areas of the specimen; this method provides pathologists with sample views of less than $0.1 \%$ of the margins of the tissue. The surgeon performing MMS examines $100 \%$ of the true surgical margin by using specially embedded and tangentially cut frozen sections.

\section{Aims of the present study}

$\mathrm{BCC}$ is the most common type of cancer in the Caucasian population. Although mortality from $\mathrm{BCC}$ is low, its importance as a public health problem has been 
understated. Interest in the etiology, biology, and treatment of BCC has increased recently because of a well-documented wordwide increase in incidence. BCC is defined as a slow growing malignant neoplasm of the skin, often characterized by extensive subclinical tumor extensions and local destruction, leading to mutilation and recurrence after surgical excision. The occurrence of metastasis is extremely rare.

Although much is known about the progression of $\mathrm{BCC}$, explaining this behayiour on a basic biologic level has been difficult.

The main aims of the investigations reported in this thesis were to obtain some explanations for both the histological and clinical growth characteristics of BCC.

Three lines of investigations were followed.

First, we attempted to elucidate the funcrion of the cellular inflammatory infiltrate surrounding BCCs and its possible role in controlling tumor growth. Therefore, investigations were undertaken to obtain insight into the extent of expression of adhesion molecules on both peritumoral endothelial cells and BCC tumor cells. Expression of these adhesion molecules on endothelial cells is essential for recruitment of $\mathrm{T}$ cells into the tissue, and expression on tumor cells is required for lymphocyte-target cell interaction (chapter 2).

We also investigated the possible role of cytoroxic $T$ cells and natural killer cells as acrive participants in immune surveillance towards BCC, by analysis of granzyme $B$ expression. The expression of granzyme B by cytotoxic $T$ cells and natural killer cells correlates with activation and subsequent cytolytic potential of these cells in vitro (chapter 3 ).

The second line of investigation concerned the critical balance between cell proliferation and cell death. Previously, prominent cell death has beern suggested as an explanation for the clinically slow growth rate of BCC. Recently, a new class of proto-oncogenes has been defined, which contribute to malignancy by inhibiting programmed cell death. We investigated the expression of the bot-2 (B-cell leukaemia/lymphoma-2) proto-oncogene in BCC. $\mathrm{BCl}-2$ expression by $\mathrm{BCC}$ rumor cells would suggest a neoplastic transformation caused by extended cell survival, and would argue against prominent cell death as a possible explanation for the typically slow growth rate of BCCs (chapter 4 ).

Moreover, a search for useful markers was undertaken to discriminate $\mathrm{BCC}$ from orher lesions that are regarded as clinical and histologic simulants. Besides bol 2, staining differences for transforming growth factor-beta and CD34 were studied, comparing $\mathrm{BCC}$ and trichoepithelioma (chapter 5).

Finally, the purpose of the third line of investigarions was to obtain clinical information about possible risk factors and subclinical tumor extensions, in order to determine parameters enabling us to: a) distinguish aggressive BCCs, characterized by extensive local invasion and disfigurement, from the more benign type of $\mathrm{BCC}$ (chapter 6), and b) propose surgical margins for primary as well as recurrent 
BCCs (chapter 7). These guidelines were formulated on the basis of two retrospective studies of 72 and $309 \mathrm{BCCs}$ respectively treated by Mohs' micrographic surgery in our department.

\section{References}

1. Satinoff MI, Wells C. Multiple basal cell naevus syndrome in ancient Egypt. Med Hist 1969;13:294-7.

2. Smith CD, Cyr M. The history of lupus erythematosus. In: Klippel JH,ed. Systemic lupus erychematosus. Rheum Dis Clins N Amer 1988;14:1-14.

3. Weber $R$, ed. Biblia sacra iuxta vulgatam versionem. Sturtgart: Deutsche Bibelgesellschaft, 1983:1695.

4. Nicaise E, ed. La grande chirurgie de Guy de Chauliac. Paris: Felix,1890.

5. Marmelzat WL. "Noli-me-tangere" circa 1754: Jacques Daviel's forgotten contribution to skin cancer. Arch Derm 1964;90:280-3.

6. Bennett JP. From noli-me-tangere to rodent ulcer: The recognition of basal cell carcinoma. Br J Plast Surg 1974;27:144-54.

7. Jacob A. Observations pespecring an ulcer of peculiar character which attacks eyelids and other parts of the face. Dubl Hosp Reprs 1827;4:232-9.

8. Krompecher E. Der Basalzellenkrebs. Jena, Gustave Fischer, 1903.

9. Williamson IJ, Cohney BC, Henderson BM. Basal cell carcinoma of the mandibular gingiva. Arch Dermatol 1967:95:76-80.

10. Piro GF, Collier DU. Basal cell carcinoma of the palm. I Am Acad Dermatol 1995:30:823-4.

11. Roth JM, Stern JB, Haupt HM, et al. Basal cell carcinoma of the sole. J Curan Pathol 1995;22:349-53.

12. Kopf $A$ W. Computer analysis of 3531 basal cell carcinomas of the skin. J Dermatol $1979 ; 6: 267-81$.

13. Roenigk RK, Ratz JL, Bailin PL, er al. Trends in the presentation and treatment of basal cell carcinoma. J Dermatol Surg Oncol 1986;12:860-5.

14. Dobson RI. Anthramine carcinogenesis in the skin of rats. I. The epidermis. I Nat Cancer Inst 1963:31:841-59.

15. Madsen A. Sudies on basal cell epichelioma of the skin. Acta Pathol Microbiol Scand 1965;177:9-63.

16. Zackheim HS. Origin of the human basal cell epithelioma. I Invest Dermatol $1963 ; 40: 283-97$.

17. Asada M, Schaart FM, De Almeida HL, et al. Solid basal cell epithelioma possibly originares from the ourer root sheath of the hair follicle. Acta Derm Venereol 1993:73:286-92. 
18. Wade TR, Ackerman AB. The many faces of basal cell carcinoma. J Dematol Surg Oncol 1978:4:23-8.

19. Lever WF, Schaumburg-Lever G. Histopathology of the skin. Philadelphia: J.B. Lippincott, 1990:632-3.

20. Yuspa SH. Cutaneous chemical carcinogenesis. J Am Acad Dermatol 1986:15: $1031-44$.

21. Kopf AW. Computer analysis of 3531 basal-cell carcinomas of the skin. J Dermatol $1979 ; 6: 267-81$.

22. Green $A$, Battistutta D. Incidence and determinants of skin cancer in a high-risk Australian population. Int J Cancer 1990;46:356-61.

23. Kaldor J. Shugg D, Young B, er al. Non-melanoma skin cancer: ten years of cancerregistry-based surweillance. Int J Dermatol 1993;53:886-891.

24. Strickland PT, Vitasa BC, Wesc SK, et al. Quantitative carcinogenesis in man: solar UVB dose dependence of skin cancer in Maryland watermen. ] Natl Cancer Inst $1989 ; 81: 1910-3$.

25. Urbach F. Geographic pathology of skin cancer. In: Urbach F, ed. The biologic effects of ultraviolet radiation (with emphasis on the skin). Oxford: Pergamon, $1969: 635-50$.

26. Diffey B.L, Tate TJ, Davis A. Solar dosimetry of the face: the relationship of natural ultraviolet radiation exposure to basal cell carcinoma localisation. Phys Medi Biol $1979 ; 24: 931-9$.

27. Bastiaans MT, Hoefnagel J], Bruijn JA, et al. Differences in age, site distribution, and sex between nodular and superficial basal cell carcinomas indicate different types of tumors. I Invest Dermatol 1998;1 10:880-4.

28. McCormack CJ, Kelly JW, Dorevitch AP. Differences in age and body site distribution of the histological subtypes of basal cell carcinoma. A possible indicator of differing causes. Arch Dermatol 1997; 133:593-6.

29. von Domarus H, Stewens PJ. Menastaric basal cell carcinoma. Report of five cases and review of 170 cases in the literature. J Am Acad Dermatol 1984; 10:1043-60.

30. Pinkus H. Skir cancer and basic research in dermatology, J lnvest Dermatol $1959 ; 33: 171-9$

31. Pinkus H. Epithelial and fibroepithelial tumors. Arch Dermatol 1965;91:24-37.

32. Bishop DM. Molecular themes in oncogenesis. Cell 1991:64:235-48.

33. Urabe A, Nakayama J. Taniguchi $S$, et al. Expression of the c-fos oncogene in chemically-induced mouse tumours and in human skin tumours. J Pathol $1992 ; 168: 281-6$

34. Takahashi S, Pearse AD, Marks R. Expression of c-fos proto-oncogene mRNA in non-melanoma skin cancer. J Dermatol Sci 1994;7:54-62.

35. van der Schroeff ], Evers L, Boat AJM, all. Ras oncogene mutations in basal cell carcinomas and squamous cell carcinomas of human skin. I Invest Dermatol $1990 ; 94: 423-5$ 
36. Ananthaswamy HN, Pierceall WE. Molecular mechanisms of ultravioler radiarion carcinogenesis. Photochem Photobiol 1990;52:1119-36.

37. Lieu FM, Yamanishi $K$, Konishi $K$, et al. Low incidence of Ha-ras oncogene mutations in human epidermal tumors. Cancer Letrers 1991;59:231-5.

38. Cerron $L$ Kerl $H$. Aberrant bel-2 protein expression provides a possible mechanism of neoplastic cell growth in cutaneous basal-cell carcinoma. I Cur Pathol $1994 ; 21: 398-403$.

39. Vogelstein B. A deadly inheritance. Nature 1990;348681-2.

40. Rady PF, Scinicariello F, Wagner RF, et al. p53 mutations in basal cell carcinomas. Cancer Res 1992;52:3804-6.

41. Ziegler AM, Leffell DJ, Kunala S, ar al. Muration hotspors due to sinnlight in the 53 gene of nonmelanoma skin cancers. Proc Nat Acad Sci USA 1993;90:4216-20.

42. van der Riet PD, Karp E, Farmer Q, et al. Progression of basal cell carcinoma through loss of chromosome 9 and inacrivation of a single p53 allele. Cancer Res $1994 ; 54: 25-7$.

43. Springate JE. The nevoid basal cell carcinoma syndrome. J Pediatr Surg 1986,21 * 908-10.

44. Gorlin RJ, Goltz RW. Multiple nevoid basal-cell epithelioma, jaw cysts and bifit rib. A syndrome. N Engl J Med 1962;262:908-12.

45. Strong LC Genetic and environmental interactions. Cancer 1977;40:1861-6.

46. Gorlin RJ. Nevoid basal-cell carcinoma syndroma. Medicine 1987;66:98-113.

47. Levenat S, Gorlin RJ, Fallet S, et al. A two-hit model for developmental defects in Gorlin syndrome. Nature Genetics 1996;12:85-7.

48. Shanley SM, Dawkins H, Wainwright BJ, er al. Fine deletion mapping on the long arm of chromosome 9 in sporadic and familial basal cell carcinomas. Hum Mol Genet $1995 ; 4: 129-33$.

49. Hahn H, Wicking $\mathrm{C}$, Zaphiropoullos $\mathrm{PG}$, et al. Mutations in the human homologue of Drosophilia patched in the nevoid basal cell carcinoma syndrome. Cell $1996: 85: 841-51$.

50. Johnson RL, Rothman AL, Xie J, et al. Human homolog of patched, a candidate gene for the basal cell nevus syndrome. Science 1996;272:1668-71.

51. Astrerbaum M, Rothman A, Johnson RL, et al. Identification of murations in the human patched gene in sporadic basal cell carcinomas and in patients with the basal cell nevus syndrome. J Invest Dermatol 1998;110:885-8.

52. Kallassy M, loftgard R, Ueda M, et al. Patched (ptch)-associated preferential expression of smoothened (smoly) in human basal cell carcinoma of the skin. Cancer Res $1997 ; 57: 4731-5$.

53. Vorechovsky I, Undén AB, Sandstedt B, et al. Trichoepitheliomas contain somatic murations in the overexpressed $P T C H$ gene: support for a gatekeeper mechanism in skin tumorigenesis. Cancer Res 1997;57:4677-81. 
54. Novick NL, Kest E, Gordon M. Adwances in the biology and carcinogenesis of basal cell arcinoma. N Y State J Med 1988; July:367-70.

55. Weinstein GD, Frost $\mathrm{P}$. Cell proliferation in human basal cell carcinoma. Cancer $\operatorname{Res} 1970 ; 30: 7248$.

56. Ono T. Clinicopathological and electron microscopic studies on basal cell epithelioma. I. Evaluation of pathogenic factory. Jap J Dermatol 1979;89 251-61.

57. Schreck $R$, Gares $O$. Curaneous carcinoma: statistical analysis with respect to duration and size of tumors, age of patients at onset and at biopsy of tumor Arch Pathol $1941 ; 31: 411-21$.

58. Jackson R. Observations on the narural course of skin cancer. Can Med Assoc J 1965;92:5,64-70.

59. Terz J], Lawrence Jr W, Cox B. Cell proliferation in human basal cell carcinoma. Cancer Res 1970;30:724-8.

60. Heenan M, Galland P. Decreased rate of DNA-chain growch in human basal cell carcinoma. Nature $1980 ; 285: 265-7$.

61. Grimwood RE, Ferris CF, Mercill BD, et al. The proliferation cells of human basal cell carcinoma are located on the periphery of rumor nodules. "I Invest Dermatol $1986 ; 86: 191-4$

62. Jacobs GH, pirrey JJ, Altini M. Prediction of aggressive behaviour in basal cell carcinoma. Cancer 1982;49:533-7.

63. Sexton M, Jones DB, Maloney ME. Histologic pattern analysis of basal cell carcinoma. I Am Acad Dermatol 1990;23:1118-26.

64. Kerr JFR, Searle J. A suggested explanation for the paradoxically slow growth rate of basal cell carcinomas that contain numerous mitotic figures. J Pathol 1972;107:41-4.

65. Morales-Ducret CRI, wan de Rijn M, LeBrun DP. bol-2 expression in primary malignancies of the skin. Arch Dermatol 1995;131:909-12.

66. Hockenberry DM, Nunez G, Milliman $\mathrm{C}$, et al.bct-2 is an inner mitochondrial membrane protein that blocks programmed cell death. Nature 1990:348:334-6.

67. Smith EB, Brysk MM. Immuniry and skin cancer. South Med J 1981;74:44-6.

68. Gupta AK, Cardella Cl, Haberman HF. Cutaneous malignant neoplasms in patients with renal transplants. Arch Dermatol 1986;122:1288-93.

69. Hoxtell EO, Mandel JS, Murray SS, et al. Incidence of skin carcinoma after renal transplantation. Arch Dermatol 1977;113:436-8.

70. Stern RS, Lange R. Non-melanoma skin cancer occuring in patients treated with PUVA five to ten years after first trearment. IInvest Dermatol 1988;91:120-4.

71. Dellon AL, Powin C, Chretien PB, et al. The immunobiology of skin cancer. Plast Reconstr Surg 1975;55:341-54.

72. Dellon AL. Host-tumor relationships in basal cell and squamous cell cancer of the skin. Plast Reconstr Surg 1978;62:37-48.

73. Weimar VM, Ceilley RI, Goeken JA. Cell-mediated immunity in patients with basal and squamous cell skin cancer. I Am Acad Dermatol 1980;2:143-7. 
74. Avgernoti $G$, Nicolis $G$, Varelczidis, et al. The dermal cellular infitrate and cell-mediated immunity in skin carcinomas. Dermatologica 1985;171:238-42.

75. Gooding $C A$, White $G$, Yatsuhashi M. Significance of marginal extension in excised basal cell carcinoma. N Engl J Med 1965:273:923-4.

76. Curson $\mathrm{C}$, Weedon D. Spontaneous regression in basal cell carcinomas. J Cutan Pathol $1979 ; 6: 437-43$

77. Hunt MJ, Halliday GM, Weedon D, er al. Regression in basal cell carcinoma: an immunohistochemical anailysis. BrJ Dermatol 1994;130:1-8.

78. Haber JMW, Tank B, Vuzewsk VD, et al. Characterization of the mononuclear infiltrate in basal cell carcinoma: a predominantly $T$-cell-mediated immune response with minor participation of Leu-7 + (natural killer) cell and Leu-14+ (B) cells. I Invest Dermatol $1988 ; 90: 289-92$.

79. Claudy AL, Viac J, Schmit D, et al, Identificarion of mononuclear cells infiltrating basal cell carcinomas. Acta Derm Venereol 1976;56:361-5.

80. Silber A, Newman W, Sasseville VG, et al. Recruitment of lymphocytes during curaneous delayed hypersensitivity in non human primares is dependent on E-selectin and wascular cell adhesion molecule 1. J Clin Invest 1994:93:1554-63.

81. Cantrell DA. Smith KA. Transient expression of interleukin 2 receptors: consequences for T cell growth. J Exp Med 1983;158:1895-911.

82. Hercend $T$, Ritz I. Schlossman SF, et al. Comparative expression of T9, T10 and Ia antigens on activated human Ts cell subsets. Hum Immunol 1981;3:247-59.

83. Reinherz EL, Kung PC, Goldstein $G$, et al. Discrete stages of human intrathymic differentiation: analysis of nomal thymocytes and leukemic lymphoblasts of T-cell lineage. Proc Natl Acad Sci USA 1980;77:1588-92.

84. Markey AC, Churchill LJ, Allen MH, er al. Activation and inducer subset phenotype of the lymphocytic infiltrate around epidermally derived cumors. I Am Acad Dermatol 1990;23:214-20.

85. Nguyen QH, Moy RL, Roth MD, er al. Expression of CD 45 isoforms in fresh and [I]-2 cultered tumor-infiltrating lymphocytes from basal cell carcinoma. Cell Immunol $1993 ; 146: 421-30$.

86. Guillen FJ, Day C., Murphy GE. Expression of activation antigens by T-cells infiltrating basall cell carcinomas. IInvest Dermatol 1985:85:203-6.

87. Ohmen JD, Moy RL, Zovich D, er al, Selecrive accumularion of T-cells according to "T-cell recepror VB gene usage in skin cancer. I Invest Dermatol 1994;103:751-7.

88. Habers JMW, Tank B, Vuzevski VD, et al. An absence of human leukocyte antigenDR and a decreased expression of $\beta 2$-microglobulin on tumor cells of basal cell carcinona: no influence on the perimmoral immune infiltrate. I Am Acad Dermarol $1989,20 \cdot 47-52$

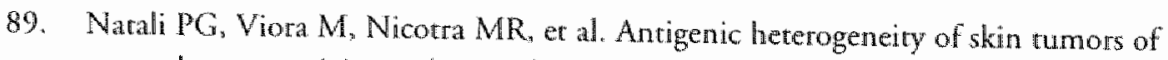
nonmelanocyte origin: analysis with monoclonal antibodies to tumor-associated antigens and to histocompatibility antigens. I Nad Cancer Inst 1983;71:439-47. 
90. Kageshita T, Ono T, Hirail $S$, et al. Ganglioside, adhesion molecule, and HLA anngen expression in basal cell carcinoma lesions. Cancer Res 1992:52:3201-7.

91. Cabrera T, Garrido V, Concha A, et al. HLA molecules in basal cell carcinoma of the skin. Immunobiol 1992;185:440-52.

92. Springer TA, Dustin ML, Kishimoto TK, et al. The lymphocyte funcrion-associated LFA-1, CD2, and LFA-3 molecules; cell adhesion receptors of the immune system. Ann Rev Immunol 1987;5:223-52.

93. Barker JNWN, Allen MH, MacDonald DM. Distribution of intercellular-adhesion molecule-1 (ICAM-1) and lymphocyte-function associated antigen-1 (LFA-1) in epidermal cumours. Clin Exp Dermatol 1990:15:331-4.

94. Taylor RS, Griffiths CEM, Brown MD, et al. Constitutive absence and interferon-y-induced expression of adhesion molecules in basal cell carcinoma. J Am Acad Dermatol 1990;22:721-6.

95. Reizner GT, Chuang TY, Elpern DJ, et al. Basal cell carcinoma in Kaua, Hawaii: the highest documented incidence in the United States. I Am Acad Dermatol $1993 ; 29: 184-9$.

96. Scotto J, Fears TR, Fruameni JF. Incidence of noti-melanoma skin cancer in the United States. NIH pub no 83-2433, 1983.

97. Marks R, Jolley D, Dorevitch AP, et al. "The incidence of non-melanoma skin cancers in an Australian population: results of a five year prospective study. Med J Aust $1989 ; 150: 475-8$.

98. Stenbeck KD, Balanda KP, Williams MJ, et al. Patterns of treated non-melanoma skin cancer in Queensland: the region with the highesc incidence rates in the world. Med J Aust 1990;153:511-5.

99. Coebergh JWW, Neumann HAM, Vrints LW, et al. Trends in the incidence of non-melanoma skin cancer in the SE Netherlands 1975-198: a registry-based study. Br J Dermatoll 1991;125:353-9.

100. Dinehart SM, Dodge R, Stanley WE, at al. Basal cell carcinoma treated with Molns surgery. A comparison for 54 younger patients with 1050 older patients. J Dermatol Surg Oncol 1992:18:560-6.

101. Milstone EB, Helwig EB. Basal cell carcinoma in children. Arch Dermatol $1973 ; 108: 523-7$.

102. Rahbari H, Mehregan AH. Basal cell epithelioma in children and teenagers. Cancer $1982 ; 127: 26-9$

103. Leffell DJ, Headington IT. Wong DS, er al. Aggressive-growth basal cell carcinoma in young adults. Arch Dermatol 1991;127:1663-7.

104. Cox NH. Basal cell carcinoma in young adults. Br J Dermatol 1992:127:26-9.

105. Dahl E, Aberg M, Rausing EL. Basal cell carcinoma. An epidemiologic study in a defined population. Cancer 1992;70:104-8.

106. Halder RM, Bridgeman-shah S. Skin cancer in African Americans. Cancer $1994 ; 75: 667-73$ 
107. Abreo F, Sanusi ID. Basal cell carcinoma in North American blacks: clinical and histopathologic study of 26 patients. J Am Acad Dermatol 1991,25:1005-11.

108. Scotto J. Kopf AW, Urbach F. Non-melanoma skin cancer among caucasians in four areas of the United States. Cancer 1974:34:1333-8.

109. Robinson JK. Risk of develloping another basal cell carcinoma. A 5-year prospective study. Cancer 1987;60:118-20.

110. Marghoob A, Kopf AW, Bart RS, et al. Risk of another basal cell carcinoma developing after treatment of a basal cell carcinoma. J An Acad Dermatol 1993;28:22-8.

111. Karagas MR, Srukel TA, Greenberg R, et al. Risk of subsequenr basal cell carcinoma and squamous cell carcinoma of the skin among patients with prior skin cancer. JAMA $1992 ; 267: 3305-10$.

112. Epstein E. Value of follow-up after treatment of basal cell carcinoma. Arch Dermatol $1973 ; 108: 798$.

113. Noodleman RF, Pollack SV. Trauma as a possible eriologic factor in basal cell carcinoma. I Dermatol Surg Oncol 1986;12:841-6.

114. Orfuss AJ. Lupus wulgaris and superimposed basal cell epitheliomas. Arch Dermatoll $1971 ; 103: 555$.

115. Burns DA, Calnan CD. Basal cell epithelioma in a chronic leg ulcer. Clin Exp Dermatol 1978;3:443-5.

116. Wechsler HL, Krugh FJ, Domonkos AN. Polydyplastic epidermolysis bullosa and development of epidermal neoplasms. Arch Dermatol 1970;102:374-80.

117. Johnson TM, Tschen J, Ho C, et al. Unusual basal cell carcinomas Cutis $1994: 54$ 85-92.

118. Lo JS, Sgouros GN, Mohs FE, et al. Basal cell carcinoma within a nevus flammeus. Int J Dermatol 1991;30:725-6.

119. Schoenfeld RJ. Epidermal proliferations overlying histiocyromas. Arch Dermatol 1964;90:266-70.

120. Rossen K. Hou-Jensen K, Werdelin B. Altered expression of $\beta-2$-microglobulin in basaJoid proliferations overlying dermatofibroma. Acta Derm Venereol 1993;73:419-21.

121. Fujisava $\mathrm{H}$, Matsushima $Y$. Hoshino $M$, et al. Differentiation of basal-cell like changes overlying dermatofibroma. Acta Derm Venereol 1991;71:354-6.

122. Rossen K, Haerslev " $T$, Hou-Jensen $\mathrm{K}$, et al. $B c l-2$ overexpression in basaloid proliferations overlying dermatofibromas and basall cell carcinomas. APMIS $1997 ; 105: 35-40$.

123. Wilson Jones E, Heyl T. Nevus sebaceous. Br J Dermatol 1970;82:99 117

124. Goldstein $G$, Whitaker $D$, Argenyi $Z$, et al. Basal cell carcinoma arising in a sebaceus nevus during childhood. I Am Acad Dermatol 1988; 18:429-30.

125. Carney $R$ G. Limear unilateral basal cell nevus with comedones: Report of a case. Arch Dermatol 1952;65:4711-6.

126. Anderson TE, Best PV. Linear basal cell nevus. Br J Dermatol 1962;74:20.

127. Gorlin R. Nevoid basal cell carcinoma syndrome. Dermatol Clin 1995;13:113-25. 
128. Plosila M, Kuistala R, Niemi K-M. The Bazex syndrome: Follicular atrophodema with multiple basal cell carcinomas, hyporrichosis, and hypohidrosis. Clin Exp Dermatol 1981;6:31-41.

129. Michaelsson $G, O l s s o n \mathbb{E}$, Westermark P. The Rombo syndrome: a familial disorder with vermiculate atrophoderma, milia, hypotrichosis, trichoepitheliomas, basal cell carcinomas, and peripheral wasodilation with cyanosis. Acta Derm Venereol $1981 ; 61: 497-503$.

130. Allsion JR. Radiation-induced basal cell carcinoma. J Dermatol Surg Oncol $1984 ; 10: 200-3$.

131. Schoolmester WL, White DR. Arsenic poisoning. South Med J 1980;73:198-208.

132. MeGibbon DH. Malignant epidermal tumors. J Cutan Pathol 1985;12:224-38.

133. Weedon D. Skin parhology. New York, 1997, Churchill Livingstone.

134. Wade TR, Ackerman AB. The many faces of basal cell carcinoma. I Dermatol Surg Oncol 1978;:23-8.

135. Lang $\mathrm{PG}$, Maize JC. Histologic evolution of recurrent basal cell carcinoma and treatment implications. J Am Acad Dermatol 1986;14:186-96.

136. Miller SJ. Biology of basal cell carcinoma (Part I). I Am Acad Dermatol $1991 ; 24: 1-13$.

137. Lang J $\mathbb{P G}, \mathrm{McKelvey} A \mathrm{C}$, Nicholson JH. Three-dimensional reconstruction of the superficial multicentric basal cell carcinoma using serial sections and a computer. Am I Dermatopathol 1987;9:198-203.

138. Metcalf JS, Maize JC. Histopathologic considerations in the management of basal cell carcinoma. Semin Dermatol 1989;8:259-65.

139. Sexton $M$, Jones DB, Malony ME. Histologic pattern analysis of basal cell carcinoma. Study of a series of 1039 consecutive neoplasms. I Am Acad Dermatol $1990 ; 23: 1118-26$.

140. Hendrix J, Parlette HL. Micronodular basal cell carcinoma. A deceptive histologic subtype with frequent dinically undetected tumor extension. Arch Dermatol $1996: 132: 295-8$.

141. Borel DM. Cutaneous basosquamous carcinona. Review of the literature and report of 35 cases. Arch Patholl 1973;95:293-7.

142. Lopes de Faria J. Basal cell carcinoma of the slkin with areas of squamous cell carcinoma: a basosquamous cell carcinoma? J Clin Pathol 1985:38:1273-7.

143. Schuller DE, Berg JW, Sherman $G_{3}$ et al. Cutaneous basosquamous carcinoma of the head and neck: A comparative analysis. Oto-laryngol Head Neck Surg $1979 ; 87: 420-7$.

144. Farmer ER, Helwig EB. Metastatic basal cell carcinoma: a clinipathologic study of seventeen cases. Cancer 1980:46:748-57.

145. Maloney ME, Jones DB, Sexton M. Pigmented basal cell carcinoma: Investigation of 70 cases. J Am Acad Dermatol 1992;27:74-8. 
146. Pinkus H. Pre-malignant fibroepithelial tumors of the skin. Arch Dermarol $1953 ; 67.598-615$.

147. Walsh N, Ackerman AB. Infundibulocystic basal cell carcinoma: newly described variant. Mod Parhol 1990;3:599-608.

148. Gooding $C A$, White $G$, Yatsuhashi M. Significance of marginal extension in excised basal cell carcinoma. N Engl J Med 1965;273:923-4.

149. Liu F, Maki $\mathrm{E}$, Warde $\mathrm{P}$, et al. A management approach to incompletely excised basal cell carcinona of skin. Int J Radiat Oncol Biol Phys 1991;20:423-8.

150. Taylor $\mathrm{AG}$, Barisoni $\mathrm{D}$. Ten years experience in the surgical treatment of basal cell carcinoma. Br J Surg 1973;60:522-5.

151. Lauritzen RE Johnson RE, Spratt JS. Pattern of recurrence in basal cell carcinoma. Surgery 1965:57:813-6.

152. Rowe DE, Carroll $\mathrm{RJ}$, Day C. Long term recurrence rate in previousily untreated (primary) basal cell carcinoma: Implication for patients followmup. J Dermatol Surg Oncol 1989:15:315-28.

153. Dellon AL, Potvin C, Chrevien PB, et al. The immunobiology of skin cancer. Plast Reconstr Surg 1975;55:341-4.

154. Richmond JD, Davie RM. The significance of incomplete excision in patients with basal cell carcinoma. Br I Plast Surg 1987;40:63-7.

155. Albright SD. Treatment of skin cancer using multiple modalities. J Am Acad Dermatol 1982;7:143-71.

156. Fleming ID, Amonette $\mathbb{R}$, Monaghan $G$, et al. Principles of management of basal and squamous cell carcinoma of the skin. Cancer 1995;75:699-704.

157. Swanson NA. Mohs surgery, technique, indications, applications and the future. Arch Dermatol 1983;119:761-73.

158. Koplin L, Zarem HA. Recurrent basal cell carcinoma. A review concerning the incidence, behaviour and management of recurrent basal cell carcinoma, wirh emphasis on the incomplerely excised lesion. Plast Reconst Surg 1980;65:656-64.

159. Dubin N. Kopf AW. Multivariate risk score for recurrence of curaneous basal cell carcinoma. Arch Dermatol 1983; 1 19:373-7.

160. Granström G, Aldenborg F, Jeppsson PA. Influence of embryonal fusion lines for re currence of basal cell carcinoma in the head and neck. Otolaryngol Head Neck Surg $1986 ; 85: 76-82$

161. Panje WR, Ceilley RI. The influence of embryology of the mid-face on the spread of epithelial malignancies, Laryngoscope 1079;89:1914-20.

162. Emmett AJJ. Surgical analysis and biological behaviour of 2277 basal cell carcinomas. Aust N Z I Surg 1990;60:855-63.

163. Dellon AL. Histologic study of recurrent basal cell carcinoma. Plast Reconser Surg $1985 ; 75: 853-9$

164. Dellon AL, DeSilva S, Connolly M, er al. Prediction of recurrence in incompletely excised basal cell carcinoma. Plast Reconstr Surg 1985;75:860-71. 
165. Dixon AY, Lee SH, McGregor DH. Histologic features predicive of basal cell carcinoma recurrence: results of mulciwariate analysis. I Cutan Pathol 1,993;137.42.

166. Haben DJ, Zirkin H, Mahler D, er al. The biologic behaviour of basal cell carcinoma. Part I. Plast Reconser Surg 1982;69:103-9.

167. Levine H. Cutancous carcinoma of the head and neck: management of massive and previously uncontrolled Jesions. Laryngoscope 1983;93,87-105.

168. Ashby MA, Smith J, Ainslie J, et al. Treatment of non-melanoma skin cancer at a large Australian center. Cancer 1989;63:1863-71.

169. Breuninger $H$, Dietz K. Prediction of subclinical tumor infiltration in basal cell carcinoma. I Dermarol Surg Oncol 1991;17:574-8.

170. Burg G, Hirsch RD, Birger K, et all. Histographic surgery: accuracy of visual assessment of the margin of basal-cell epithelioma. J Dermatol Surg Oncol 1975:1:21-4.

171. Menn H, Robins P, Kopf AW, et al. "The recurrent basal cell epithelioma. Anch Dermatol 1971;103:628-31.

172. Roenigk RK, Roenigk HH. Current surgical management of skin cancer in dematcology. J Dermatol Surg Oncol 1990;16:136-51.

173. Randle HW. Basal cell carcinoma. Identification and treatment of high-risk patient. Dermatol Surg 1996;22:255-61.

174. Granström $G$, Aldenborg F, Jeppsson P-H. Influence of embryonal fusion lines for recurrence of basal cell carcinomas in the head and neck. Otolaryngol Head Meck Surg 1986;95:76-82.

175. Mora RG, Robins P. Basal cell carcinomas in the center of the face: special diagnostic, prognostic, and therapeutic considerations. J Dermatol Surg Oncol 1978;4: $315-21$.

176. Orengo IF, Salasche SI, Fewkes J, et al. Correlation of histologic subtypes of primary basal cell carcinoma and number of Mohs stages required to achieve a tumor-free plane. I Am Acad Dermatol 1997:37:395-7.

177. Hendrix Jn JD, Parlerte HL. Duplicitous growh of infiltrave basal cell carcinoma. Analysis of clinically undetected tumor extent in a paired case-control study. Dermatol Surg $1996: 22: 535-9$.

178. Wolf DJ, Zirelli IA. Surgical margins for basal cell carcinoma. Arch Dermatol $1987: 123: 340-4$.

179. Breuninger $\mathbb{H}$, Dietz $K$. Prediction of subclinical tumor infiltration in basal cell carcinoma. J Dermatol Sutg Oncol 1991;17:574-8.

180. Niparko JK, Swanson NA, Baker SR, et al. Local control of auricular, perianuicular, and external canal cutaneous malignancies with Mohs surgery. Laryngoscope $1990 ; 100: 1047.51$

181. Rapini RP. On the definition of Mohs surgery and how it determines appropiate surgical margins. Arch Dermatol 1992;128:673-8.

182. Welch ML, Anderson LL, Grabski WJ. How many nonmelanoma skin cancers require Mohs micrographic surgery? Dermatol Surg 1996:22:711-3. 
183. Rosin MP, Miller SI, Schwab D, et al. Molecular analysis of effecriveness of Mohs' surgical technique. Jancet $1996 ; 347: 1692-3$.

184. Rowe DE, Carroll RJ, Day Jr CL Long term recurrence rate in previously untreated (primary) basal cell carcinoma: Implication for patients follow-up. I Dermatol Surg Oncol $1989 ; 15 ; 315-28$.

185. Rowe DE, Carroll RJ, Day Jr CL. Mohs surgery is the treatment of choice for recurrent (previously treated) basal cell carcinoma. J Dermatol Surg Oncol 1989:15: $424-31$.

186. Silverman MK, Kopf AW, Grin CM, et al. Recurrence rates of treated basal cell carcinomas. Part 1: Overview. J Dermatol Surg Oncol 1991:17:713-8.

187. Silverman MK, Kopf AW, Grin CM, et al. Recurrence rates of treared basal cell carcinomas. Part 2: Curettage-electrodesiccation. J Dermatol Surg Oncol 1991;17: $720-6$.

188. Silverman MK, Kopf AW, Bart RS, et al. Recurrence rates of treated basal cell carcinomas. Part 3: Surgical excision. J Dermatol Surg Oncol 1992;18:471-6.

189. Silverman MK, Kopf AW, Gladsrein AH, et al. Recurrence rates of treated basal cell carcinomas. Part 4: X-ray therapy. J Dermatol Surg Oncol 1992;18:549-54.

190. Nordin P, Larkö $O$, Stenquist B. Five-year results of curettage-cryosurgery of selected large primary basal cell carcinomas on the nose: an alternative treatment in a geographical area underserved by Mohs surgery. $\mathrm{Br}^{*}$ ] Dermatol 1997;136:180-3.

191. Lindgren $G$, Larkö $O$. Long-term follow-up of cryosurgery of basal cell carcinoma of the eyelid. I Am Acad Dermatol 1997:36:742-6.

1192. Kuflik EG, Gage AA. Recurrent basal cell carcinoma treated by cryosurgery. I Am Acad Dermatol 1997;37:82-4.

193. Zacarian SA. Cryosurgery of cutaneous carcinomas. An 18-year study of 3.022 parients with 4.228 carcinomas. J Am Acad Dermatol 1983;9:947-56.

194. Avril M-E, Auperin A, Margulis A, er al. Basal cell carcinoma of the face: surgery or radiotherapy? Results of a randomized study. Br J Cancer 1997:76:100-6.

195. Smith SP, Foley EH, Grande DJ. Use of Mohs micrographic surgery to establish quantitarive proof of heightened tumor spread in basall cell carcinoma recurrent following radiorherapy. J Dermatol Surg Oncol 1990;16:1012-6.

196. Wilder RB, Shimm DS, Kittelson JM, et al. Recurrent basal cell. carcinoma treated with radiation therapy. Ardh Dermatol 1991;127:1668-72. 
Chapter 2

\section{Adhesion molecule expression in basal cell carcinoma}

M.E.J.M. Verhaegh, R.C. Beljaards, J.C.I.M. Veraart,

R. Hoekzema, H.A.M. Neumann

Eur I Dermatol 1998;8:252-5 
Summary

Basal cell carcinomas (BCCS) are frequently associated with a peritumoral mononuclear infiltrate. Until now, the function of this inflammattory infiltrate and its possible role in the control of tumor growth is unclear. Mechanisms controlling endothelial and target cell adhesiveness for leukocytes are important features in the development of a specific local immune response. The expression and distribution of the adhesion molecules ICAM-1, VCAM-1 and E-selectin by microvascular endothelial cells and tumor cells, together with their leukocyte receptors LFA-1, VLA-4 and CLA respectively, were studied in $33 \mathrm{BCC}$ of different histological subtypes. In normal skin ICAM- 1 is expressed by resting endothelial cells, whereas VCAM-1 and E-selectin expression correlates with endothelial activation. The epidermis in normal conditions displays no ICAM- 1 . VCAM-1, or E-selectin expresision. In BCC, endothelial ICAM-1 expression was only slightly increased compared to normal skin. whereas expression of endothelial VCAM-1 and E-selectin was low or absent in all BCC s examined. Peritumoral infiltrates contained mostly LFA-1 expressing lymphocytes, with minimal VLA-4 and CLA positivity. In none of the cases studied adhesion molecule expression of BCC tumor cells was identified.

The lack of significant expression of adhesion molecules on peritumoral vascular endothelial cells and BCC tumor cells is not in favour of specific cell-mediated immunity as an important mechanism in limiting BCC lumor spread. 
Chapter 2 Adhesion molecule exparession in basal cell carcinoma

\section{Introduction}

BCC of the skin, dhe most common human cancer, is a locally inwasive tumor thar grows slowly and rarely metastasizes.

BCCs are frequendy associated with a peritumoral mononuclear cell infiltrate that may represent a specific antitumor response. 1,2 The infiltrate surrounding $B C C$ tumor islands largely consists of $\mathrm{T}$ cells with a predominance of the CD $4+/ \mathrm{T}$. helper over the CD8+1T-cytotoxic subset, similar to that found in typical delayed hypersensitivity reactions. ${ }^{3,4}$ Natural killer cells and B-cells are seen in much lower numbers. To enable infiltrating leukocytes to influence tumor growth, these cells need to be recruited from the circulation furst. The entry of lymphocytes from the circulation into an organ is mediated by interactions between adhesion molecules on vascular endothelial cells (so called vascular adressins) and circulating leukocytes (termed homing receptors).' Recent interest has focused upon three cytokine-inducible leukocyte adhesion molecules, designated intercellular adhesion molecule-1 (ICAM-1), vascullar cell adhesion molecule-1 (VCAM-1) and Eselectin. $6 \times 8$ Another area of interest involving adhesion molecules concerns leukocyte-tumor cell interaction. In order ro control the proliferation of the tumor by the surrounding cellular infiltrate, expression of adhesion molecules on tumor cells is thought to be required, and it has been suggested that failure to express ad. hesion molecules would enable malignant cells to escape immunosurveillance? In the present study, the distribution of a selected panel of adhesion molecules and their T-cell ligands is tested on a group of thirty-three BCCs of either the nodularand morpheaform type.

\section{Material and methods}

\section{Tissue Specimens}

Fresh-frozen skin samples were obtained from patients undergoing Molss' micro-graphic surgery (MMS) for BCC, present on sumexposed areas of the head. The BCCs consisted of 23 with nodular type and 10 with morpheaform type growth, according ro histopathological analysis. Samples were immediately frozen in liquid nitrogen and stored at minus $70^{\circ} \mathrm{C}$ until required. Normal skin specimens $(\mathrm{n}=5)$ from various body sites were used as a control.

\section{Immunahistochemistry}

Frozen sections, $5 \mu \mathrm{m}$, were cut, air dried, and fixed for ten minutes in acetone. Primary antibodies were applied at the appropiate dilution for 30 minutes at room temperature. Dependent on the species of the primary antibodies, the secondary antibady was either a biotinylated goat anti-mouse immunoglobulin or a biociny- 
lated goat anti-rat immunoglobulin (Dakoparts, Copenhagen). In the third step, streptavidin-peroxydase was applied. HRP-enzyme activity was visualized using 3-amino-ethylcarbizole as a chromogen. Sections were counterstained with hematoxylin. For positive controls the following specimens were used: positive patch test reaction biopsy sites (ICAM-1, E-selectin) and in-vitro TNF- $\alpha$ stimulated skin (E-selectin, VCAM-1).

Negative controls included omission of the primary antibody and substiturion of the primary antibody by an irrelevant one. Primary antibodies used are summarized in Table 1 .

Table I Monoclonal antibodies used in the study

clone

MEM111

CLBLA $1 / 2$

ENA-1

HECA 452

489

4921
Specificity

ICAM-I

LFA-I

Eselectin

CLA

YCAM-1

VLA-4
Dilution

11000

1.150

1200

125

$1: 2250$

1,100
Source

$\mathrm{SB}$

CLB

SB

PDFU

Harlan

IT

(SB, Sanbio, Uden, The Netherlands, POFU, Pathology department Free University, Amster. dam, The Netherlands, CLB, central laboratory of the Red Cross blood trensfusion service, Am sterdam, The Netherlands, IT, Immunotech, Marselle, France, 489 was kindy provided by Dr. Hanlan, Seatte, USA)

\section{Quantification}

Expression of endothelial ICAM-1, VCAM-1, and E-selectin was quantified according to the following criteria: 0 , no staining; $+/-$, weak focal staining; + , moderate staining of whole vessels; ++ , strong staining of whole vessells. The extent of MoAb staining of leukocytic infiltrates was quantified as follows: 0 , no staining; $+/, 0-25 \%$ positively stained cells;,$+ 25-50 \%$ positive cells;,$++ 50-75 \%$ positive cells, and,$+++>75 \%$ positive cells.

\section{Results}

In 15 cases (solid-rype $n=6$, morpheaform type $n=9$ ) of the 33 BCCs studied, only a discrete inflammatory infiltrate was present around the tumor islands. The remaining cases (solid-type $n=17$, morpheaform $n=1$ ) displayed a more prominent lymphocytic infiltrate especially perivascularly and at the base of the tumor. In none of the cases lymphocytes were found infiltraring the BCC rumor nests. 
In normal skin moderate ICAM- $\mathbb{1}$ expression ( + ) of whole vessels was found, whereas endothelial E-selectin and VCAM-1 stained negative (0).

When compared to normal skin, increased endorhelial ICAM-1 expression $(+1++)$ in BCC was mainly restricted to those peritumoral areas, where a prominent lymphocytic infiltrate was present (Fig. la).

In BCC tumor specimens, endothelial VCAM-1 and E-selectin expression was eirher undetectable or weakly positive $(+-)$ with granular staining of individual endothelial cells (Fig. 1b,c). No endothelial staining differences between solid and morpheaform BCC were observed. The peritumoral infiltrate contained mostly LFA-1-expressing cells $(++)$, with fewer lymphocytes variably sraining for VLA-4 $(+/-)$ and CLA $(+/-)$. The results are summarized in Table II.

In none of the cases examined ICAM-1, VCAM-1 or E-selecrin expression could be identified on tumor cells or overlying benign epidermal keratinocytes.
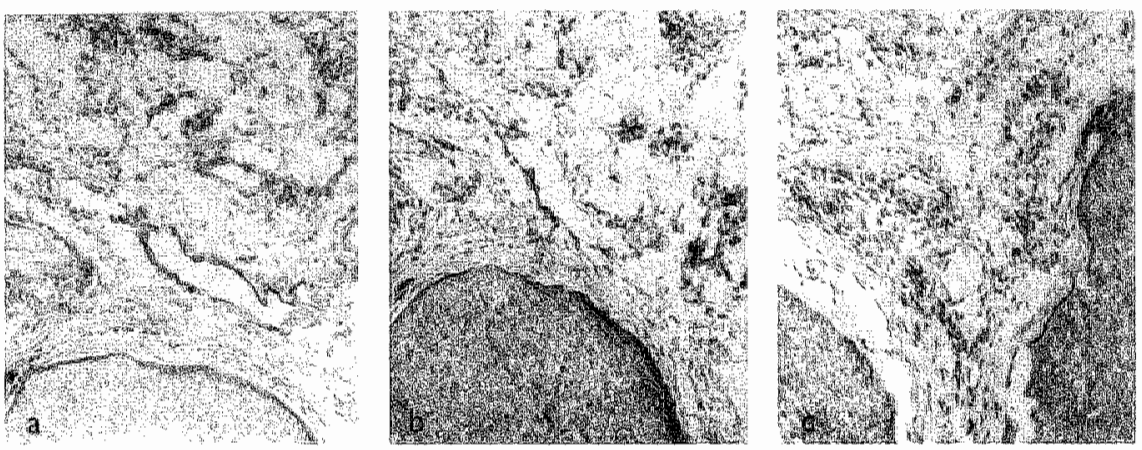

Figure 1a. BCC stained for ICAM-1. Tumor cell expression of ICAM-1 is absent whereas endothelial cells show enhanced ICAM-1 expression. ( $x 200)$. b. BCC stained for VCAM-1. Moderate staining for VCAM-1 is observed on wascular endothelium. (x 200) $\mathrm{C}$. BCC stained for E-selectin. Only minimal staining for E-selectin is observed on vascular endothelium. $(x 200)$.

Table II, Distribution and staining nitensity of vascular adhesion molecules (ICAMC1, VCAM-1, E-selectin) and their 1 cell ligands (LA-1, VLA-4, CLA) in thity three basal cell carcinomas.

Antibody
LCAM-1




\section{Discussion}

In the last decade, several reports concerning the local immune response in $\mathrm{BCC}$ have attempted to elucidate the function of the cellular inflammatory infiltrate surrounding these skin cancers and their possible role in controlling tumor growth. ${ }^{1-3}$ A tumor-specific cellular immune response is considered to be associated with adhesion molecule expression on endothelial cells allowing recruitment of $T$ cells into the tissue, and on tumor cells for lymphocyte-target cell interaction. 9

At least five molecular pathways operate to recruit $T$ cells to the peripheral tissue through endothelial cel!/T-cell interactions that include ICAM-1 and ICAM-2/LFA-1, VCAM-1/VLA-4, E-selectin/CLA and hyaluronic acid/CD44 pathways. ${ }^{10}$

ICAM- 1 , which is inducible by IFN- $\gamma$ and TNF- $\alpha$, is expressed by a wide variety of cells, including resting endothelial cells and binds virtually all circulating white cells. ${ }^{6,7} \mathrm{E}$-selectin and VCAM-1 expression correlates with endothelial cell activation and these molecules are both inducible by TNF- $\alpha$ and IL-1. ${ }^{11}$ VCAM- 1 contributes to selective recruitment of $T$ cells and eosinophils but not neutrophils, ${ }^{12}$ whereas E-selectin functions as a tissue-selective endothelial cell-adhesion molecule at sites of chronic inflammation and is thought to be important for recruitment of skin-homing T-lymphocytes expressing the cutaneous lymphocyteassociated antigen (CLA). ${ }^{13,14}$

First, recent literature concerning adhesion molecules in $\mathrm{BCC}$ will be summarized. Taylor et al, who studied thirty BCCs, demonstrated negative ICAM-1 staining of tumor cells. ${ }^{15}$ This was confirmed by Barker et al who examined six. cases of $\mathrm{BCC} .{ }^{16}$ However, they demonstrated a more intensely ICAM-1 expression of dermal endothelial cells in areas of inflammatory infiltrate compared to normal skin. Groves et al showed variable staining patterns of endothelial Eselectin expression in a group of eleven BCCs. ${ }^{17,18}$ Finally, Pentel et al in a group of 16 BCCs and Viac et al in a group of five BCCs, described similar results. 19,20 BCC tumor cells were all ICAM-1, E-sellectin and VCAM-1 negative. Endothelial cells within the surrounding of the rumors weakly expressed ICAM-1 and rarely expressed E-selectin and VCAM-1.

In the present study, we investigated the expression and distribution of the adhesion moleculles ICAM-1, VCAM-1 and E-selectin, together with their leukocyte receptors LFA-1, VLA-4 and CLA respectively, in thirry-three BCCs of different histological subrypes. We demonstrated moderate ICAM-1 and minimal VCAM-1 and E-selecrin expression by endothelial cells of blood vessels surrounding BCC tumor lobules. This is in accordance with the staining results of their counter molecules, i.e. the demonstrated positivity for LFA-1 and the minimal staining for VLA-4 and CLA. 
chapter 2 Adheston moteculde expression in basal cell carcinoma

Both in nodular-and morpheaform type BCCs, expression of ICAM-1, E-selectin and VCAM-1 by tumor cells or overlying benign epidemal keratinocytes was absent.

Adhesion of lymphocytes to targer cells via surface molecules is thought to be tequired for $\mathrm{T}$-lymphocyte mediated immune reactions. It has been postulated that BCC can escape immunosurveillance because of the absence of adhesion mollecules on tumor cells, preventing binding of T lymphocytes. 16 This could explain the histological observation that T cells do not infiltrate BCC tumor lobules. The inability of BCC tumor cells to express adhesion molecules is not absolute. Taylor et al presented a study where they demonstrated induction of ICAM-1 expression on tumor cells after BCC tissue had been incubated in witro with IFN- $\psi^{15}$ They put forward three possible explanations for the discrepancy between in two and in witro observations: a) insufficient in vivo cytokine levels, b) a barrier preventing cytokines from reaching and interacting with tumor cells in wivo, and c) lower level of sensiriviry.

In our opinion, the absence of adhesion molecules on BCC tumor cells as well on the overlying epidermal keratinocytes as demonstrated in this study, together with the moderate ICAM-1 and minimal VCAM-1 or E-selectin expression on the surrounding peritumoral endothelial cells could probably best be explained by insufficient in wivo cytokine levels. Insufficient in wiwo cytokine levels can be caused by an insufficient amount of activated T-lymphocytes responding to antigen stimulation, or, as Yamamura et al demonstrated, an accumulation of type-2 instead of rype-1 T-helper cells, resulting in the production of $1 \mathrm{~L}-4,1 \mathrm{~L}-5$. and 1L-10 cytokines instead of the cytokines IL-2, IFN- $\gamma$ and TNF- $\alpha .^{21-23}$ In summary, endothelial cells are critical elements in the ewolution of cellular infiltrates. Our results indicate "resting" endothelial cells around BCCs, with moderate ICAM-1 expression and minimal E-selectin/VCAM-1 expression, recruiting particularly LFA-I positive lymphocytes in both nodular and norphealorm type BCC. Histologically, these LFA-1 positive lymphocytes do not infiltrate the BCC tumor lobules. This may be due to the absence of adhesion molecule expression on BCC tumor cells, interfering with the essential cell-cell contact berween the effecror immume cell and target cell.

\section{References}

1. Hurt MI, Halliday GM, Weedon D, Cooke BE, SrC. Barmetson R. Regression in basal cell carcinoma: an immunohistochemical analysis. $\mathrm{Br}$ J Dermatol $1994 ; 130: 1-8$.

2. Curson C, Weedon D. Spontaneous regression in basal cell carcinomas. J Cutan Pathol $1979 ; 6: 432-7$. 
3. Habets JM, Tank B, Vuzevski VD, van Reede EC, Stolz E, van Joost T. Characteriwation of the mononuclat influrate in basal cell carcinoma: a predominanty $T$ cellmediared immune response with minor participation of Leu-7+(natural killen) cells and Leu-14 + (B) cells. J Inwest Dermatol 1988; 90:289-92.

4. Claudy AL, Viac J, Schmint D, Alario A, Thivolet J. Identification of mononuclear cells infiltrating basal cell carcinomas. Acta Derm Venereol 1976;56:361-5.

5. Shimizu $Y$, Newman W, Tanaka $Y$, Shaw S. Lymphocyte interactions with endothelial cells. Immunol Today 1992;13:106-12.

6. Springer TA. Adhesion receptors of the immune system. Nature 1990; 346:425-34.

7. Barker JNWN, MacDonald DM. Cutaneous lymphocyte trafficking in the inflammatory dermatoses. Br. I Dermatol 1992;126:211-5.

8. Growes $\mathbb{R W}$, Ross EL, Barker INWN, MacDonald DM. Vascular cell adhesion molecule-1: Expression in normal and diseased skin and regulation in wivo by interferon gamma. I Am Acad Dermatol 1993;29:67-72.

9. Mickoloff BJ, Griffiths CEM, Barker INWN. The role of adhesion molecules, chemotactic factors, and cytokines in inflammarory and neoplastic skin disease- 1990 update. I Invest Dermatol 1990;94:151S-7S.

10. Wakina $H$, Takigawa. E-selectin and vascular cell adhesion molecule- 1 are critical for initiating trafficking of helper-inducer/memory $\mathrm{T}$ cells in psoriatic plaques. Arch Dermaral 1994:130:457-63.

11. Pober JS, Bevilacqua MP, Mendrick DL, Lapierre LA, Fiers W, Gimbrone Jr MA. Two distinct monokines, "nterleukin 1 and tumor necrosis factor, each independently induce the biosynthesis and transient expression of the same antigen on the surface of cultured human vascular endochelial cells. J Immunol 1986;136:1680-7.

12. Perzelbater P, Pober IS, Keh A, Braverman IM. Inducibility and expression of microvascular endothelial adhesion molecules in lesional, perilesional, and uninvolved skin of psoriaric patients. I Invest Dermatol 1991;103:300-5.

13. Picker 1.y, Kishimoto TK, Smith CW, Warnock TK, Butcher EC WLAM-1 is an adhesion molecule for skin-homing $T$ cells. Nature 1991;349:796-9.

14. Bos JD, de Boer OJ, Tibosch E, Das PK, Pals ST. Skin-homing T lymphocytes: detection of curancous lymphocyteassociated antigen (CLA) by HECA-452 in normal. Ihuman skin. Arch Dermatol Res 1993;285:179-83.

15. Taylor RS, Griffiths CEM, Brown MD, Swanson NA, Nickoloff B). Constirutive absence and interferon- $\gamma$-induced expression of adhesion molecules in basal cell carcinoma. J Am Acad Dermatol 1990;22:721-6.

16. Barker JNWN, Allen MH, MacDonald DM. Distribution of intercellular-adhesion molecule-1 (ICAM-1) and lymphocyte-function-associated antigen-1 (LFA-1) in epidermal tumours. Clin Exp Dermatol 1990;15:331-4.

17. Groves RW, Allen MH, Barker JNWN, Hatskard DO, MacDonald DM. Endothelial leucocyte adhesion molecule-1 (ELAM-1) expression in cutaneous inflammation. Br J Dermatol 1991;124:117-23. 
18. Groves RW, Allen MH, Ross EL, Ahsan G, Barker INWN, MacDonald DM. Expression of selectin ligands by cutaneous squamous cell carcinoma. An J Parhol $1993 ; 143: 1220-5$.

19. Pentel M, Helm KF, Malony MM. Cell surface molecules in basal cell carcinomas. Dermatol Surg 1995,21:858 61.

20. Expression of adhesion receptors in epidermal numors: correlation wh TNFo expressing cells. Anticancer Res 1995:15:551-6.

21. Guillén FJ, Day CL, Murphy GF. Expression of activation antigens by T cells infiltrating basal cell carcinomas. II Invest Dermatol 1985;85:203-6.

22. Markey AC, Churchill LJ, Allen MH, MacDonald DM. Acrivation and inducer subset phenotype of the lymphocytic infiltrate around epidermally derived tumors. I Am Acad Dermatol 1990:23:214-20.

23. Yamamura M, Modlin RL, Ohmen JD, Moy RL. Local expression of antiinflammatory cytokines in cancer. J Clin Invest 1993;91:1005-10. 

Chapter 3

\section{Immunohistochemical localization of granzyme B in peritumoral infiltrates of basal cell carcinoma}

M.E.J.M. Verhaegh, P.C. Wever,

H.A.M. Neumann, R. Hoekzema

Br. I Dermatol 1997;137:1012-4 (correspondence) 


\section{Summary}

BCCs are frequently associated with a peritumoral mono-nuclear cell infiltrate that may represent a specific antitumor response. The infiltrate largely consists of $T$ cells with a predominance of the CDA+ $/$ Thelper over the CDB+/T cytotoxic subset, together with small numbers of natural killer cells. Besides identifying the predominant cell phenotype, information about the activation status of lymphocytes also is essential. The presence of characteristic granules in the cytoplasm of cytotoxic T cells and natural kilm ler cells correlates with activation and subsequent cytolytic potential of these cells in wtro. These cytoplasmic gramules contain a pore-forming protein, perforin, and several homologous serine proteinases called granzymes. The action of granzymes results in the apoptotic death of the target cell. Recently, monocional antibodies became available, directed against a serine proteinase called granzyme $B(g r B)$. We investigated the expression of grB in 10 cases of $\mathrm{BCC}$, of which 8 were untreated and 2 had been treated once with intralesional interferon-a.2b. (Double) staining with anti-CD3 or anti-CD8 antibodies was performed to identify the phenotype of grB positive cells. Immune infittrates of BCC were compared with other skin tumors.

The results show that only a limited number of cytotoxiC T cells surrounding BCC tumor lobules expressed grB. The small number of cells in the inflltrate that stained for gra mostly represented NK cells.

We conclude that in patients with $B C C$, the "activated" state of peritumoral T cells apparently does not lead to expression of granzymes and subsequent cytolytic activity by cytotoxic T cells present in these infiltrates. 


\section{Introduction}

BCC represents the most common human malignancy in light-skinned individuals and accounts for at least $75 \%$ of all skin cancer. ' Characteristically, BCC is a locally invasive tumor that grows slowly and rarely merastasizes. Increased numbers of lymphocytes surrounding BCC tumor lobules have been observed. ${ }^{2}$ The infiltrate surrounding $\mathrm{BCC}$ tumor islands largely consists of $\mathrm{T}$ cells with a predominance of the CD4+/T-helper (Th) over the CD8+/T-cytotoxic (Tc) subset (Th/Tc ratio of $1.9 \pm 0.8$ ), similar to that found in rypical delayed hypersensitivity reactions. ${ }^{3-4}$ Natural killer cells $(\mathrm{NK})$ and B-cells are seen in much lower numbers. ${ }^{3-4}$

Several studies have shown expression of acrivation markers on $30-50 \%$ of $\mathrm{T}$ cells in BCC. ${ }^{5-7}$ Regression of BCC, either spontaneously or after local immunotherapy, correlates with increased numbers and activation state of peritumoral T cells, whereas aggressive tumor behaviour is associated with decreased numbers of $\mathrm{T}$ cells in peritumor areas. ${ }^{4}$ Although these data suggest a cell mediated anti-tumor response, the role of cells with cytolytic potential, i.e. Tc and NK cells in immune surveillance of $\mathrm{BCC}$, is not clear.

Tc and NK cells are the effector cells in major histocompatibilicy complex (MHC)-restricted and in non-MHC-restricted cellular cytotoxicity, respectively. ${ }^{8}$ These cytotoxic reactions are important in the elimination of tumor cells and virus infected cells and for the process of allograft rejection. ${ }^{\text {? }}$

Our objective was to study the expression of grB by cells present in immune infiltrates surrounding BCC, as an indicator of cytolytic activity against the tumor. $\mathrm{GrB}$ is a serine proteinase stored in granules of activated Tc and NK cells and an unique activation marker of cytotoxic cells. ${ }^{10-12}$ We investigared the expression of $\mathrm{grB}$ in 10 cases of $\mathrm{BCC}$, of which 8 were untreated and 2 had been treated with a single intralesional injection of interferon (IFN)- $\alpha 2$ b. (Double) staining with anti-CD 8 or anti-CD3 antibodies was performed to identify the phenotype of grB positive cells. Immune infiltrates of BCC were compared with those of squamous cell carcinoma ( $\mathrm{SCC}$ ), melanoma and inflamed seborrhoeic keratosis (SK). This is the first study on expression of grB in human skin cancer.

\section{Methods}

Tissue specimens

Formalin fixed, paraffin embedded biopsies or surgical specimens of nonulceraring nodular-type BCC $(n=8), \operatorname{SCC}(n=5)$, melanoma $(n=4)$ and SK $(n=3)$, selecred for the presence of moderate to marked peritumoral infiltrates, were ob- 
tained from the files of the Department of Parhology, University Hospital Maastricht, The Netherlands.

Two cases of clinically diagnosed (non-biopsied) non-ulcerating nodular BCC, localized in the face, were treated by a single intralesional injection of $1,5 \times 10^{6} \mathrm{IE}$ IFN- $02 \mathrm{~b}$, followed by excision after 48 hours.

\section{Immunohistochemical staining}

Serial paraffin sections, $4 \mu \mathrm{m}$ thick, were placed on 3-aminopropyltriethoxysilane (Sigma, ST.Louis, USA) coated glass slides. Slides were deparaffinized and rehydrated and endogenous peroxidase activity was blocked by immersion for $20 \mathrm{~min}$ in methanol containing $0.3 \% \mathrm{H}_{2} \mathrm{O}_{2}$. Immunoreactivity was restored by boiling of slides in $10 \mathrm{mM}$ sodium citrate (Merck, Darmstadt, Germany), $\mathrm{pH} 6.0$, for 10 min, after which the slides were rinsed with tapwater, distilled water and phosphate buffered saline (PBS). Slides were stained at room temperature using the streptavidin-biotin horseradish peroxidase (HRP) complex technique. The staining sequence was: $10 \%$ normal goat serum in PBS for $15 \mathrm{~min}$; monoclonal antibody (mAb) $\mathrm{grB}-7$ or $\operatorname{IgG}_{2 \mathrm{a}}$ isotype control $\mathrm{mAb}$ in PBS (final concentration 2.5 $\mu \mathrm{g} / \mathrm{mL}$ ) for 1 hour; biotin-labeled rabbit anti-mouse $\left.\mathrm{F}(\mathrm{ab})_{2}\right)_{2}$ fragments (DAKO, Glostrup, Denmark) in PBS containing 10\% normal human serum (PBS-NHS) for $30 \mathrm{~min}$; HRP-conjugated streptABComplex (DAKO) in PBS-NHS for 30 min. HRP activity was detecred using 3,3-diaminobenzidine terrahydrochloride as dye and $\mathrm{H}_{2} \mathrm{O}_{2}$ as substratum yielding a brown color. Slides were counterstained with Mayer's hematoxylin, dehydrated and mounted.

For double staining of $\mathrm{mAb}$ grB7 with anti-CD3 polyclonal antibodies or antiCD8 $\mathrm{mAb}$, sequential staining techniques with alkaline phosphate- and HRP labelled secondary antibodies were used, respectively. CD3 or CD8 were detected using 3-amino-9-ethylcarbazolle as the dye (red) and $\mathrm{H}_{2} \mathrm{O}_{2}$ as substratum. MAb $\mathrm{grB7}$ was detected using naphtol-AS-MX phosphatate as substratum and Fast Blue BB as dye (blue).

Immunohistoiogical evaluation

Cells displaying a strong cytoplasmic granular staining were considered grBt. GrB expression was scored by counting the number of posirive cells per field in two representative areas by high power field magnification $(400 \mathrm{x})(0: 0 ;+: 1-5 ;++$ : $6-10 ;+++: 11-20 ;+++t ;>20$ posirive cells per field). Double stained slides were used for phenotypic analysis of gr $\mathrm{B}+$ cells. Cells staining positive for $\mathrm{gr} \mathrm{B}$ as well as either $\mathrm{CD} 3$ or $\mathrm{CD} 8$ were considered Tc cells. Cells staining positive for grB only were considered NK cells. 
Table L. Quantification of granzyme 8 positive cells per high power field magnification (400x)

\begin{tabular}{|c|c|c|c|c|}
\hline Case & Tumor & $g r d+$ & $9 r d+7 c$ & Tumor thuasion \\
\hline त) & BCC & + & 0 & 0 \\
\hline 2 & $B C C$ & + & 0 & 9 \\
\hline 3. & $B C C$ & ++ & 4 & o \\
\hline 4 & $B C C$ & + & 0 & o \\
\hline 5. & $\mathrm{BCC}$ & + & 0 & 0 \\
\hline 6. & $\mathrm{BCC}$ & 0. & 9 & 0 \\
\hline 7. & $B C C$ & + & 0 & 0 \\
\hline 8. & $B C C$ & + & 0 & 0 \\
\hline 9. & $\mathrm{BCC}+1 \mathrm{FN}-\mathrm{a} 2 \mathrm{~b}$ & $t+t$ & + & 0 \\
\hline 10 & $\mathrm{BCC}+1 \mathrm{FN}-2 \mathrm{2b}$ & $+t+$ & to & 0 \\
\hline 11. & $\mathrm{scc}$ & $+++t$ & $1+$ & $+t$ \\
\hline 12 & scc & $t+t$ & + & $t+$ \\
\hline 13 & $\mathrm{scc}$ & +++ & 1 & t \\
\hline 14 & $\mathrm{scc}$ & $++t$ & + & + \\
\hline 15 & sec & $++1+$ & $+t$ & + \\
\hline 16. & Melanoma & $+t$ & t & + \\
\hline 17 & Melanoma & $t+$ & + & + \\
\hline 18 & Melanoma & $t+t$ & 4 & t+ \\
\hline 19 & Melanoma & +++ & + & + \\
\hline 20 & sk & $+t+$ & + & + \\
\hline$F$ & $\mathrm{SK}$ & $t+t$ & $t$ & $t+$ \\
\hline & SK & $+t+$ & + & $t$ \\
\hline
\end{tabular}

GrB + gramzyme B positive cels, grB+ TC glanzyme B positive CDB+ T-citotoxle cells, Tumor invaston, invasion of granzyme B positive cells into the tumor lobules)

\section{Results}

A prominent lymphocytic infiltrate localized preferentially in perivascular areas and adjacent to and at the base of tumor nests was observed in all eight cases of untreated nodular BCC. Significant numbers of lymphocytes were not observed within the tumor.

To study the distribution and phenotype of $\mathrm{grB}+$ cells in these infiltrates immunohistochemical single-colour and double-colour staining techniques were used. The results are summarized in Table I. Despite the presence of large numbers of $\mathrm{CD} 3+$ and $\mathrm{CD} 8+\mathrm{T}$ cells, there was a striking absence of $\mathrm{grB}+$ cells in peritumoral areas (Fig. 1). The limited number of cells that expressed $\mathrm{grB}$ did not co-express $\mathrm{CD} 3$ or $\mathrm{CD} 8$ and consequently represented NK cells. GrB+NK cells were scattered mainly throughout the peritumoral stroma, but did not infiltrate the rumor 


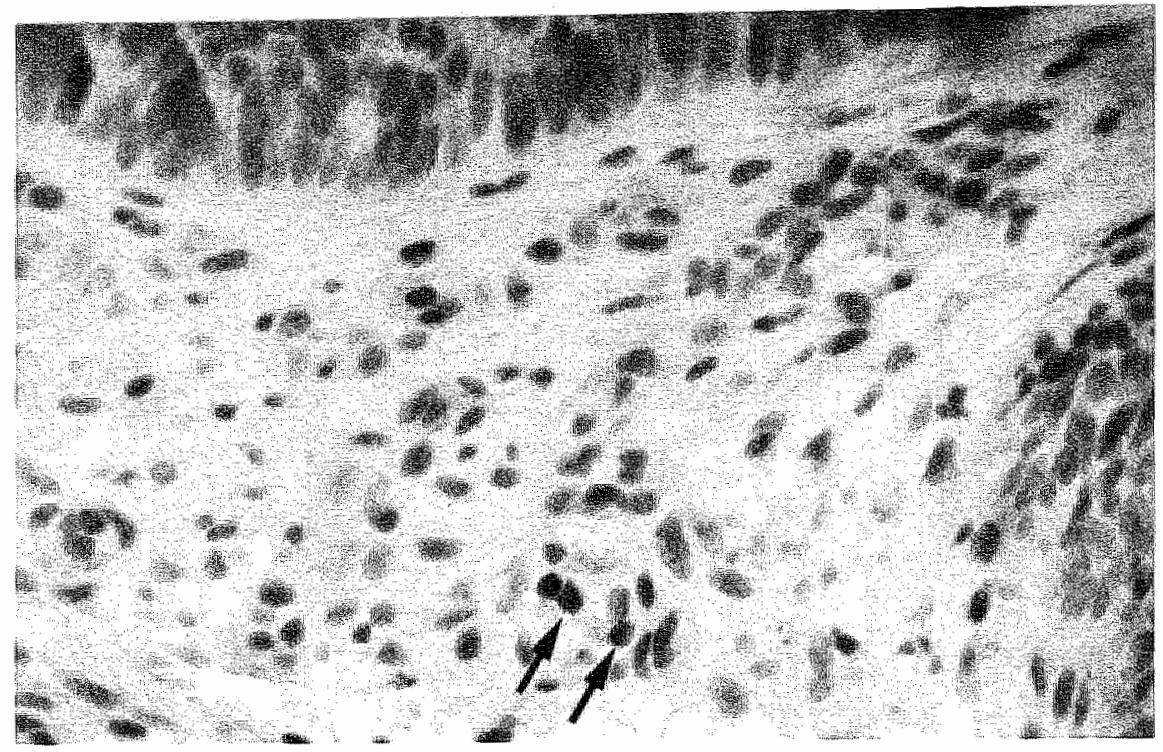

Figure 1. BCC, single stained for grB. The peritumoral infiltrate does not show significant grB expression. Some grB + cells (arrows) are observed inside or close to capillaries (x 200$)$.

lobules. Relatively larger numbers of $\mathrm{grB}+\mathrm{NK}$ cells as well as sporadic grB $+\mathrm{Tc}$ cells (defined as cells staining double positive for grB and either CD3 or CD8) were present inside or close to capillary lumina, distant from the tumor islands. In the two cases of $B C C$ treated with IFN- $\alpha 2 b 48$ hours prior to resection, the number of gr $\mathrm{B}+$ cells in perivascular areas appeared to be increased in comparison with untreated BCC. Again these cells were mainly NK and not Tc cells. GrB+ cells adjacent to the tumor were, however, still sporadic (Fig. 2a,b).

In contrast to BCC; SCC, melanoma and SK showed significant numbers of grBt NK cells not only "crowding" directly adjacent to the tumor, but also irvading tumor islands (Fig. $3 a, b)$. The number of grB + Tc cells in these conditions was small, although increased compared to BCC.

The inability to derect significant numbers of grB + Tc cells was not due to a technical problem, as gr $B+$ To cells were easily detecred in the same experiment in $c y$ tospin preparations of peripheral blood lymphocytes from a healthy donor (not shown). 


\section{Chaptet 3 Inmumohistochentical localiation of grantyme a}

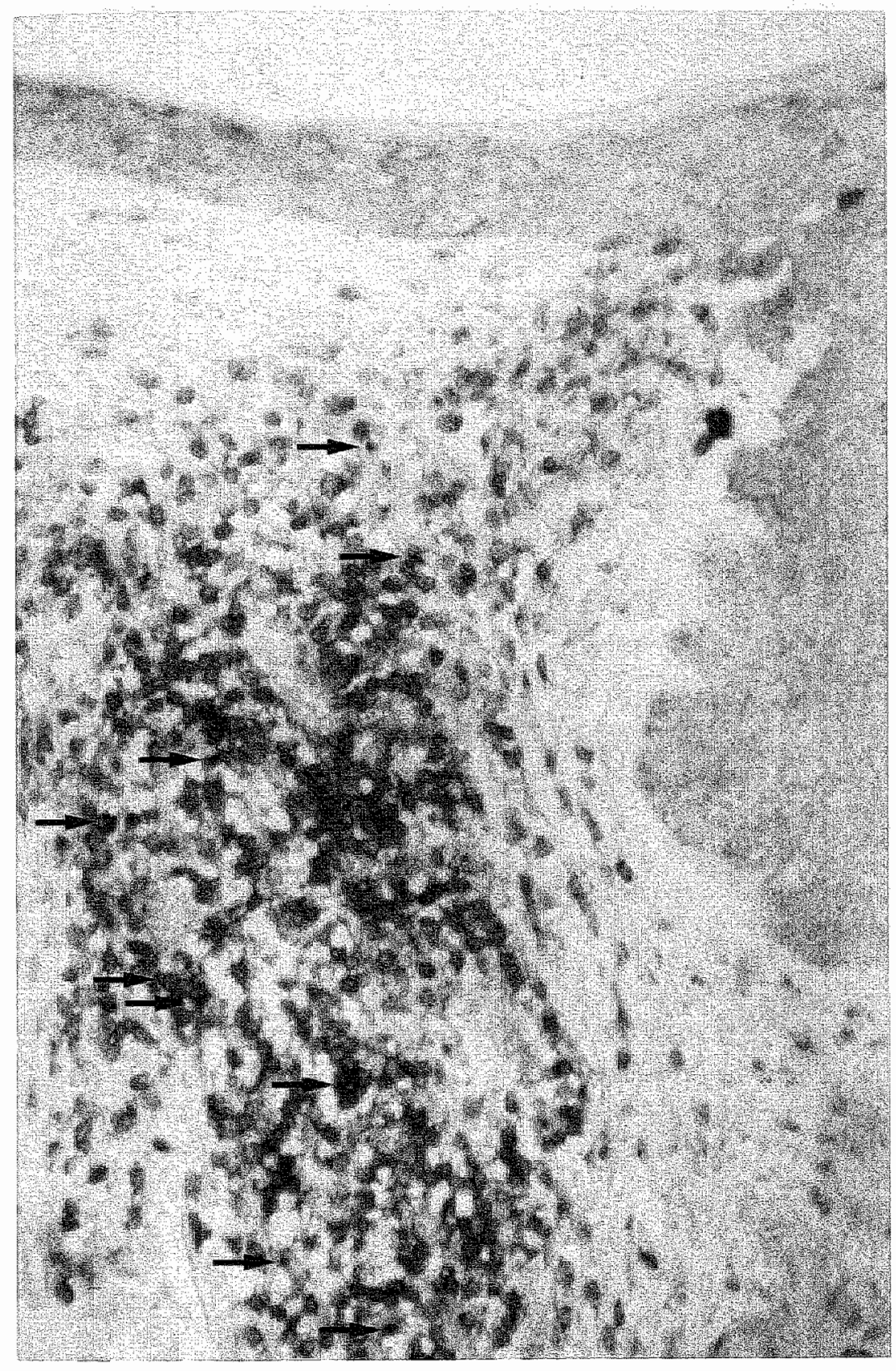

Figure 2a. BCC, 48 hours after a single intralesional injection with $1 F N * 0: 2 b$, doublestained for $\mathrm{CD} 3$ and grB (arrows). The number of peritumoral grB + cells is still small (x 100). 


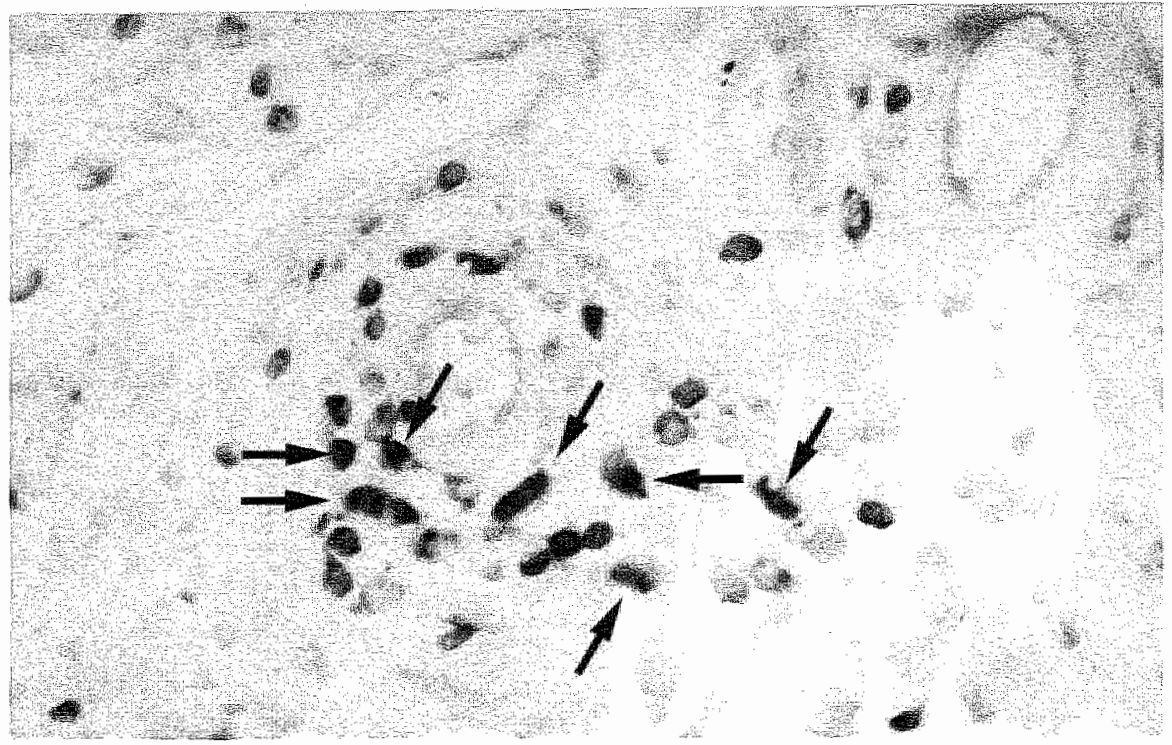

Figure $2 \mathrm{~b}$. BCC, 48 hours after a single intralesional injection with $\mathbb{F N}-\alpha 2 \mathrm{~b}$, doublestained for CD3 and grB (arrows). Detail of a dermal capillary, close ${ }^{0} 0$ an $\mathrm{FN}-\alpha 2 \mathrm{~b}$ treated $\mathrm{BCC}$. NK cells expressing gr $B$ but not $C D 3$, as well as $T$ cells that do not express gr $B$ are invading the dermis $(x 320)$.

\section{Discussion}

In the last decade, several reports concerning the local immune response in BCC have attempted to elucidare the function of the cellular inflammatory infiltrate surrounding these skin cancers and their possible role in controlling tumor growth. ${ }^{13,14}$ The relatively benign tumor-behaviour, the areas of spontaneous regression and the therapeutic response to intralesional administration of cytokines, such as IL-2, IFN- $\gamma$ and IFN- $\alpha$, are in favour of a "specific" anti-tumor immune response in $\mathrm{BCC}$. The fact that the stromal inflammatory reaction surrounding $\mathrm{BCC}$ is usually mild, that T cells do not rouch or infiltrate BCC tumor lobules and that the frequency of $\mathrm{BCC}$ in immunosuppressed patients is only slightly increased compared with SCC, argue against a specific anti-tumor response. ${ }^{15}$

Different cells of the immune system have been implicated in tumor immunity, although their precise role remains unclear. It seems likely that helper T lymphocytes, lymphokine-secreting T lymphocytes, cytotoxic T lymphocytes, natural killer cells, macrophages and Langerhans cells each play some part in the process. ${ }^{15}$ Hunt et al showed a statistically significant increase of the number of $T$ lymphocytes in actively regressing BCCs compared with non-regressing $\mathrm{BCCs}$. This was caused by accumulation of CD4 4 cells, which are usually helper and/or cyrokine-secreting lymphocytes, without any difference in CD8+cells. ${ }^{14}$ 

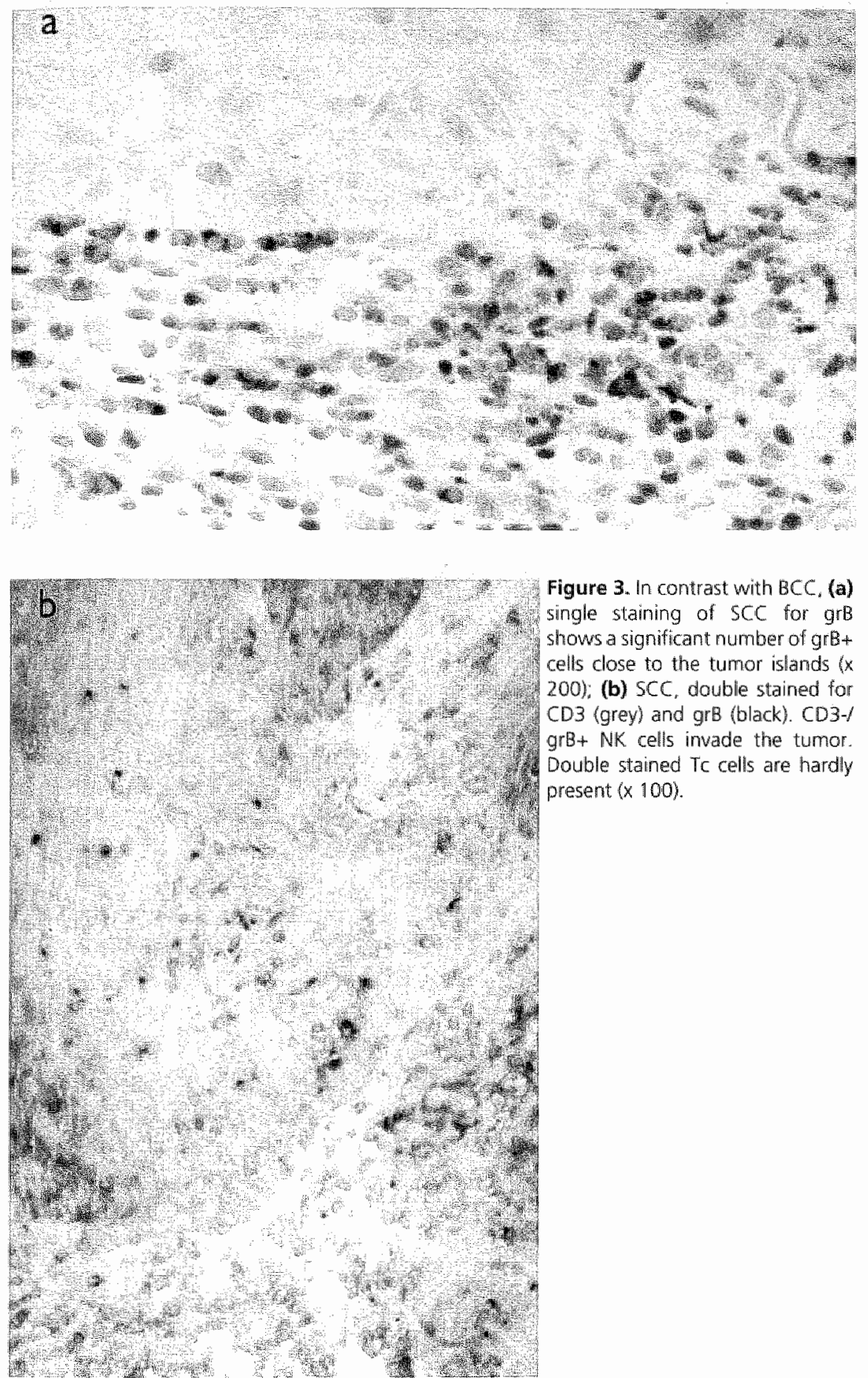

Figure 3. In contrast with $B C C_{-}$(a) single staining of SCC for grB shows a significant number of grB + cells close to the tumor islands ( $\mathrm{x}$ 200); (b) SCC, double stained for CD3 (grey) and grB (black). CD3-1 grB $+N K^{\prime}$ cells invade the tumor. Double stained Tc cells are hardly present $(x 100)$. 
These results are consistent with those of Mozzanica et al who studied therapeutically induced regression of BCCs. After intralesional therapy with IFN- $\alpha 2 \mathrm{~b}$, an increased number of $C D 4+T$ cells was observed within the tumor regions, thus confirming the importance of this cell rype in mediating rumor regression. 16 In this study, we investigated the possible role of CD8 $+\mathrm{T}$ cells and $\mathrm{NK}$ cells as other acrive participants in immune surveillance towards $\mathrm{BCC}$.

Cytotoxic T cells (CD 8+) induce target cell death eirher by surface interaction berween Fas ligand and Fas or by the release of perforin and granzymes. ${ }^{17}$ Both lyric pathways induce apoptosis. The perforin/granzyme pathway is a mechanism of cell-mediated cytoroxiciry that is critical for the function of CD8+ lymphocytes and NK cells. ${ }^{18}$ After effector-target cell conjugation, the effector cell releases its cytolytic granules containing perforin and granzymes. Perforin undergoes polymerization in the presence of calcium and forms channels in the target cell membrane. The perforin-formed channels are postulated to alow the entry of granzymes into target cell cytoplasm. The action of granzymes results in the apoptotic death of the target cell.

Shresta et al clearly showed that grB is one of the mollecules required for the induction of DNA fragmentarion in target cels. ${ }^{18}$ The expression of $\mathrm{grB}$ can be used as a specific, functional marker for activated cytotoxic $T$ cells in wivo, i.e. grB characterizes a specific T cell population that has been stimulated by recognition of its target. Only these T cells own lytic potential.

Until now, grB expression has been demonstrated in synovial tissue from parients with rheumatoid arthritis and osteoarthritis, in acute renal and cardial allograft rejection and in Reed-Sternberg cells of Hodgkin's disease. ${ }^{19-22}$ Phenotypic analysis, in these studies, showed that expression of $\mathrm{grB}$ was restricted to $\mathrm{CD} 56+\mathrm{NK}$ cells and CD3+ cells, representing cytotoxic T-lymphocytes.

To the best of our knowledge, our study represents the first report on expression of granzymes in immune infiltrates of skin cancer in man. Although we studied a limited number of tumors, we conclude that in BCC, in contrast with SCC, melanoma and "inflamed" $S K$, hardly any grB expression is present in peritumoral areas. In accordance with the relative paucity of NK cells in $\mathrm{BCC}^{3,4}$ we detected a limired number of grB $+\mathrm{NK}$ cells. Furthermore, we were unable to demonstrate silg. nificant numbers of $\mathrm{T} c$ cells expressing gr $\mathrm{B}$ in $\mathrm{BCC}$, despite the presence of $\mathrm{CD} 8+$ $T$ cells. It has previously been shown that there is a relative pauciry of CD8+ T cells in the infiltrate surrounding BCC tumor islands. 3,4 Here, we show that the cytotoxic potential of these cells, as reflected by expression of $\mathrm{grB}$, also appears to be limited. It remains to be established if this lack of $\mathrm{grB}$ expression by $\mathrm{CD} 8+\mathrm{T}$ cells in perimumoral areas is caused by local absence of lymphokines or by cerrain local (tumor-derived) immunosuppressive factors.

We analyzed 2 BCCs after a single dose of IFN- $\alpha 2 b$. After 48 hours increased numbers of grB $+N K$ cells as well as grB + Tc cells appeared to be recruited from 
the circulation. This recruitment may involve "vascular targeting", mediated by cell adhesion moleculles and may initiate tumor regression. ${ }^{23}$ Yet, further studies are required to monitor cytotoxic events during local immunotherapy of $\mathrm{BCC}$. In order to develop more efficient immuno-therapeurical strategies for BCC, future studies should focus more on the induction of granzymes or other cytolytic components by tumor-infiltrating Tc cells, as these cells are considered to be antigen-specific and therefore more effective in tumor cyrolysis than NK cells. In conclusion, we investigated the functional role of cytotoxic lymphocytes in $\mathrm{BCC}$, by analysis of grB expression. The majority of peritumoral Tc cells did not express grB, whereas only a limited number of $\mathrm{gr} B+N K$ cells was present. As gr B is considered to be instrumental in cell-mediated cytolysis by cytotoxic lymphocytes, these results are indicative for a minor role of these cells in anti-tumor immune responses in BCC.

\section{Acknowledgments}

Moab GrB7 was a kind gift of Prof. C.E. Hack from the Central Laboratory of the Netherlands Red Cross Blood Transfusion Service in Amsterdam.

\section{References}

1. Miller SJ. Biology of basal cell carcinoma (Part I). J Am Acad Dermatol 1991;24:1-13.

2. Claudy AL, Viac J, Schmitt D et al. Identification of mononuclear cells infiltrating basal cell carcinomas. Acra Derm Venereol 1976;56:361-5.

3. Habets JM, Tank B, Vuzevski VD et al. Characterization of the mononuclear infiltrate in basal cell carcinoma: a predominantly $\mathrm{T}$ cell-mediated immune response with minor participation of Leu-7+ (natural killer) cells and Leu-14+ (B) cells. J Invest Dermarol 1988;90:289-92.

4. Deng IS, Brod BA, Saito R, Tharp MD. Immunc-associated cells in basal cell carcinomas of skin. J Cutan Pathol 1996;23:140-6.

5. Nguyen QH, Moy RL, Roth MD et al. Expression of CD45 isoforms in fresh and 11-2-cultured tumor infiltrating lymphocytes from basal cell carcinoma. Cell Immunol 1993;146:421-30.

6. Guiflén FJ, Day CL, Murphy GF. Expression of activation antigens by 'T" cells infiltrating basal cell carcinomas. J Invest Dermatol 1985;85:203-6.

7. Markey AC, Churchill LJ, Allen MH et al. Activation and inducer subset phenotype of the lymphocytic infiltrate around epidermally derived tumors. J Am Acad Dermatol 1990;23:214-20. 
8. Topalian SL, Solomon D, Rosenberg SA. Tumor specific cytolysis by lymphocytes infultaring human melanomas. J Immunol 1989;142:3714-25.

9. Liu C-C. Young LHY Young JD-E. Lymphocyte-mediated cytolysis and disease. N Eng J Med 1996;335:1651-9.

10. Kummer JA, Kamp AM, Tadema TM et al. Localization and identification of granzymes $A$ and B-expressing cells in normal human lymphoid tissue and peripheral blood. Clin Exp Immunol 1995;100:164-72.

11. Grifiths GM, Mueller C. Expression of perforin and granzymes in vivo: porential diagnostic markers for activated cytotoxic cells. Immunol Today 1991;12:415-9.

12. Kummer JA, Kamp AM, wan Kawijk $M$ et al. Production and characterization of monoclonal antibodies raised against recombinant human granzymes $A$ and $B$ and showing cross reactions with natural proteins. J Immunol Method 1993:163:77-83.

13. Curson C, Weedon D. Spontaneous regression in basal cell carcinomas. J Cutan Pathol $1979 ; 6: 432-7$.

14. Hun MJ, Halliday GM, Weedon D et al. Regression in basall cell carcinoma: an immunohistochemical analysis. Br J Dermatol 1994;130:1-8.

15. Miller S] Biology of basal cell carcinoma (Part II). I Am Acad Dermatol $1991 ; 24: 161.75$.

16. Mozzanica N, Cartaneo A, Boneschi V er al. Immunohistological evaluation of basal cell carcinoma inmunoinfiltrate during intralesional trearment with alpha, -interferon. Arch Dermatol Res $1990 ; 282: 3111-7$.

17. Schröter M, Lowin B, Borner C, Tschopp J. Regulation of Fas (Apo-1/CD95)-and perforin-mediated lytic path ways of primary cyrotoxic $T$ lymphocytes by the proto-oncogene bit-2. Eur J Immunol 1995:25:3509-19.

18. Shresta $S$, Heusel JW, Macivor DM et al. Granzyme B plays a critical role in cytotoxic lymphocyte-induced apoptosis. Immunol rev 1995;146:211-21.

19. Kummer JA, Tak PP, Brinkman BMN et al. Expression of granzymes A and B in synovial tissue from patients with themmatoid arthritis and osteoarthritis. Clin Immunol Immunopath 1994;73:88-95.

20. Kummer JA, Wever PC, Kamp AM et al. Expression of granzyme A and B proteins by cytoroxic lymphocytes involved ith acute renal allograft rejection. Kidney Int $1995: 47: 70-7$.

21. Hameed A, "Truong LD, Price $\mathrm{V}$ et al. Immumohistochemical localization of granzyme $B$ antigen in cyrotoxic cells in human tissues. Am J Pathol 1991;138:1069-75.

22. Oudjans JJ, Kummer JA, Jiwa $M$ et al. Granzyme B expression in Reed-Sternberg cells of Hodgkin's disease. Am J Pathol 1996;148:233-40.

23. Ferrara N. Natural killer cells, adhesion and tumor angiogenesis. Nar Med $1996: 2: 971-2$. 
Chapter 4

Expression of the apoptosis-suppressing protein bcl-2 in non-melanoma skin cancer

M.E.J.M.Verhaegh, C.J.G.Sanders,

J.W.Arends, H.A.M.Neumann

Br J Dermatol 1995:132:740-4 
Summary

Basal cell carchoma (BCC) is a typically slow growing malignant tumor, composed of cells similar to those in the basal area of the epidermis. We investigated the expression of bcl-2 (B-cell leukemia/lymphoma-2) in BCC and also in squamous cell carcinoma (SCC) of the skin. The proto-oncogen bct-2 encodes an inner mitochondrial membrane protein that inhibits programmed cell death (apoptosis). The protein is expressed in basal cells in normal human epithelium, but not in the suprabasal cell layers. Immunomistochemical localization using a monocional anti-bct-2 antibody revealed positive $b c t-2$ expression of all BCCs (15 patients). 5CCs failed to express bc/-2 (5 patients). The positive bol-2 staining of BCC tumor cells supports the hypothesis that BCCs originate from the basal layer of the epidermis. The bCt-2 expression of BCC tumor cells also suggests a neoplastic transformation caused by extended cell survival instead of cell proifferation. This kind of neoplastic growth is possibly associated with less aggressive tumor behaviour. 
Chapter 4 Expression of the apoptosis-suppressing protein bel-2

\section{Introduction}

$\mathrm{BCC}$ and SCC of the skin are malignant neoplasias that originare from epidermal keratinocytes. Both predominantly develop on sun-exposed sites either as a result of UV-induced DNA damage or UV-induced immunosuppression. ${ }^{\prime}$ BCCs are typically slow growing tumors, often taking months to years to reach significant proportions. ${ }^{2}$ Several explanations for this clinical behaviour have been proposed: 1) tumoral prolongation of the S-(DNA synthesis) phase of the cell cycles ${ }^{3} 2$ ) a small percentage of tumor cells that are acrively proliferating; ${ }^{4} 3$ ) tumor regression in response to host immune factors; ${ }^{5}$ 4) limited enzyme lysis of adjacent connective tissue; ${ }^{6}$ 5) mechanical resistance of the dermis counteracting the expansion of the carcinoma. ${ }^{6}$ Kerr ett al, describing the phenomenon of apoptosis (selfdestruction of single cells), suggested that prominent cell dearh in BCC may provide an alternative explanation for their clinically slow growth rate. ${ }^{7}$

A fundamental feature of carcinogenesis is deregulation of normal cellular genes termed proto-oncogenes. ${ }^{8}$ The products of activated ras oncogenes and mutated tumor suppressor genes act to cause increased cellular proliferation.?

Recendy however, a new class of proto-oncogenes has been defined, which contributes to malignancy by inhibiting programmed cell death. ${ }^{10} \mathrm{BCl}-2$ ( $\mathrm{B}$-cell leukemia/lymphoma-2) proto-oncogen is the first member of this class of oncogenes, and was originally discovered at the chromosomal translocation point $\mathrm{t}(14 ; 18)$ in a large proportion of follicular lymphomas. ${ }^{11} \mathrm{Bcl}-2$ shows the unique functional role of blocking programmed cell death, referred to as apoptosis, independent of affecting proliferarion. Studying normal adult skin, Lu et al found bct-2 expression in the basal cell layer and the upper third of mature hair follicles but not in the suprabasal cell layers of the epidermis. ${ }^{12}$ Since BCC is thought to arise from basal kerarinocytes, bcl- 2 expression is expected on $\mathrm{BCC}$ tumor cells. On the other hand the described prominent cell death in $\mathrm{BCC}^{7.13}$ would imply an absence of bol-2 expression. Squamous cell carcinoma that originates from suprabasal kerarinocytes would be expected to be negative for bot -2 .

The present study was performed to identify the expression of bol-2 in normal skin, BCC and SCC.

\section{Material and methods}

\section{Tissue specimens}

Fresh frozen skin samples were obtained from patients undergoing Mohs' micrographic surgery for BCC (15 patients) and SCC (5 patients), excised from sunexposed areas of the head. The BCCs consisted of 7 with morphea-like and 8 with solid-type histoparhological growth-patterns. Frozen samples were stored at 

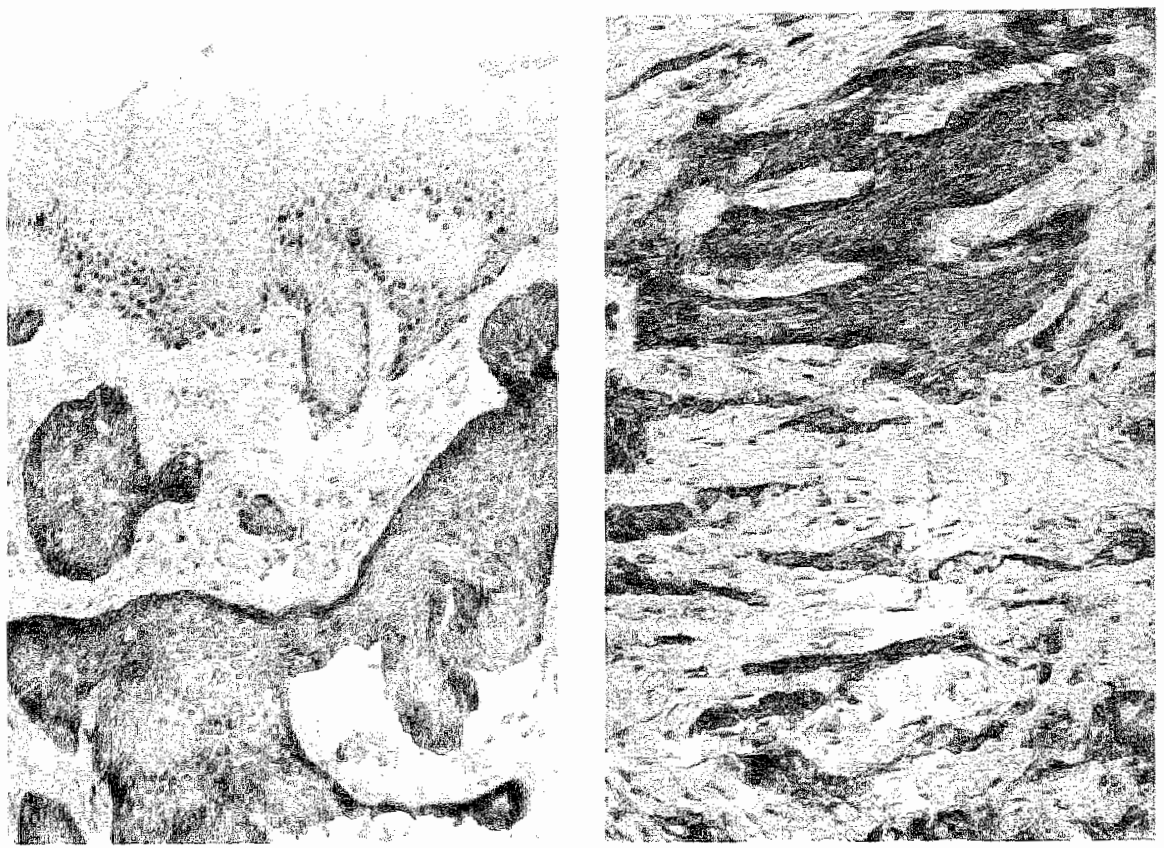

Figure 1. immunohistochemical analysis of cryostat sections of $B C C$ with prominent homogeneous cytoplasmic bcl-2 expression. (a) Solid-type $90 x$, (b) Morphea-type $200 x$.

$-70^{\circ} \mathrm{C}$. Normal skin from various body sites was obtained from the tips of elliptical skin biopsies of dermal naevi and processed in the same way. Five formalinfixed specimens of BCC were also included.

\section{Immunohistochemical staining}

Frozen sections of $5 \mu \mathrm{ra}$ thickness were cut, placed on gelatine-alum coated slides, and fixed in acerone at $4^{\circ} \mathrm{C}$ for $10 \mathrm{~min}$. After rinsing with PBS, slides were incubated with primary anribody (see below). Sections of $3 \mu \mathrm{m}$ were cut from routinely processed specimens (fixed in $4 \%$ buffered formaldehyde overnight at room temperature, embedded in paraffin wax), placed on slides coated with gelatinealum, and dried overnight at $56^{\circ} \mathrm{C}$. The specimens were subsequently dewaxed in xylene and dehydrated in absolute ethanol. Endogenous peroxidase was blocked with $3 \% \mathrm{H}_{2} \mathrm{O}_{2}$ in absolute methanol at room temperature (RT). Slides were rehydrated in decreasing concentrations of ethanol, and rinsed in distilled water. Subsequently, the slides were placed in jars containing $250 \mathrm{cc} 10 \mathrm{mmolvl}$ citrate in distilled water, $\mathrm{pH}=6$, placed in a conventional microwave oven, microwaved until boiling, and then microwaved for another $10 \mathrm{~min}$. The jar was than removed 

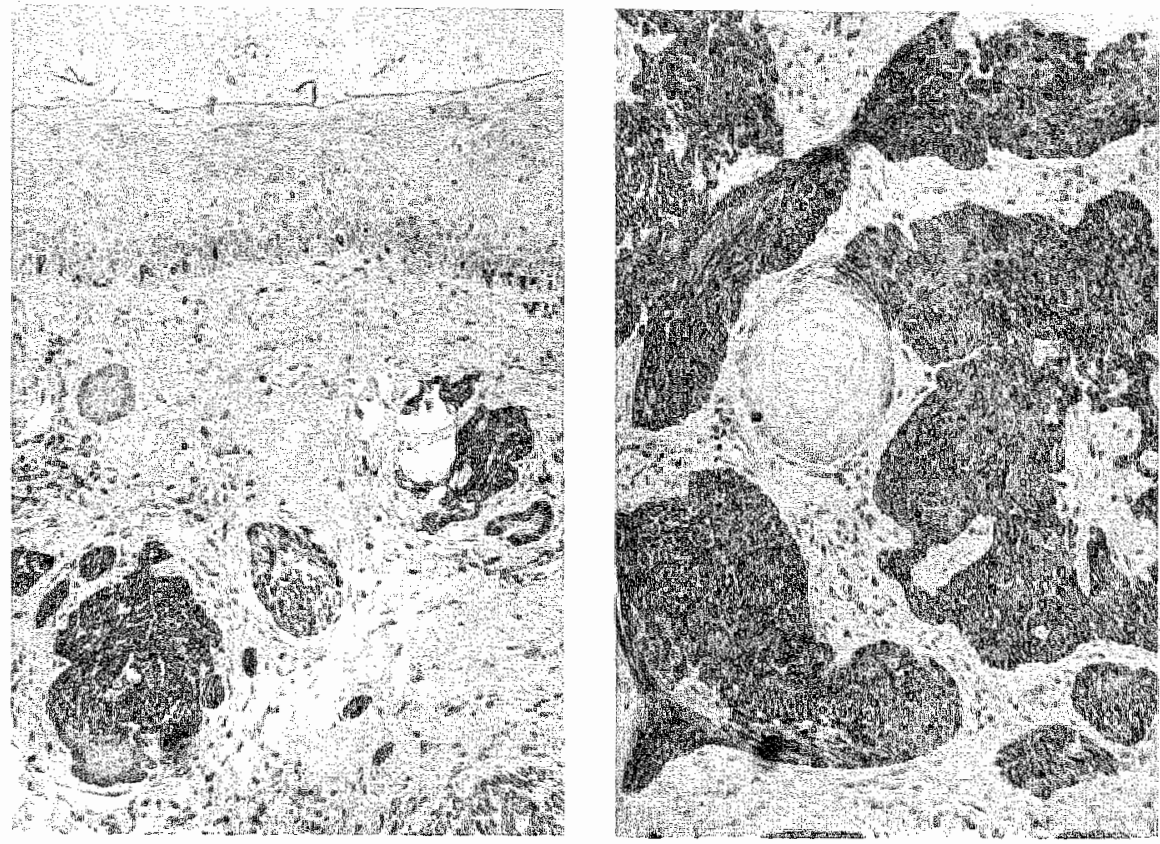

Figure 2. Immunohistochemical analysis of paraffin sections of solid-type basal cell carcinoma with homogeneous cytoplasmic bc/-2 expression. (a) $40 x$, (b) $140 x$.

from the microwave oven, and left to cool for 20 min until RT was achieved. Slides were rinsed in PBS.

The slides (both frozen sections and microwave treated) were than incubated with the monoclonal antibody $b c l-2$ (clone 124, purchased from DAKO, Denmark) for 45 min at RT. A biotin-streptavidine detection system was employed with DAB (Sigma) as the chromogen. Slides were washed repeatedly with PBS, and incubated with biotinylated rabbit-anti-mouse for $30 \mathrm{~min}$. After rinsing in PBS, slides were incubated with the peroxidase-conjugated streptavidin label (DAKO) for 30 min than rinsed in PBS, and subsequently incubated with $D A B / I$ midazol (1:1) for 5 min. Sections were counterstained with Mayers hematoxylin, dehydrated, clleared in xylene, and mounted with Entellan. Normal skin sections served as positive controls. Negative controls were rreated as above with exception of the bcl-2 antibody incubation step. 


\section{Results}

Twenty specimens from 15 patients with BCC (15 frozen-samples, 5 formalinsamples), five SCCs (frozen-samples) and five normal skin specimens (frozensamples) were assessed for bol-2 expression by immunohistochemical staining. A fine granular brown cyroplasmatic staining of the cells with bct-2 was considered positwe. In the epidermis of normal skin bol-2 expression was uniformly present in the basal cell layer. Epithelial cells in the infundibulum of hair follicles also showed expression of bct-2, as well as cells lining the duct of sebaceous glands and eccrine sweat glands. The suprabasal layers were consistently negative. All BCCs were bel-2 positive with prominent fine granular cytoplasmic staining throughout the lesions. There were no staining differences between frozen (Fig. Ia,b) and formalin (Fig. 2a,b) fxed materials or between solid and morphea-type growthparterns of BCC. SCCs failed to express bct-2.

\section{Discussion}

Both in normal tissue development and malignant cell growth, the maintenance of cell numbers reflects a balance between cell proliferation and cell dearh. Excessive growth may result from uncontrolled cellular proliferation as well as from limited cell dearh. To date, most of our knowledge concerning oncogenic events has concentrated on mechanisms of increased cellular proliferation. Only recently attention has focused on the possible consequences of abnormal or defecrive cell death. ${ }^{14}$

Apoptosis is one of two forms of cell death that have been described in mammalian tissue, the other being the pathological process of necrosis. Apoptotic cells characteristically show decrease in volume, clumping of chromatin and nuclear fragmentation, and blebbing of the cell membrane forming apoptotic bodies. 15 This mode of physiological cell deletion appears to be intrinsically programmed, and serves ats a regulator of tissue size. The blocking of this programmed cell death is atributed to the gene products of the bel-2 (B-cell leukemia/lymphoma-2) protooncogene. $B c-2$ is localized at the inmer site of mitochondrial membranes and is expressed in lymphoid cells and several epithelal tissues (skin and inrestine) where it is derectable in basal cells but not in more superficial differentiated cells. ${ }^{16}$ It has been suggested that this patretn of expression assists the survival of stem cells while preventing the overaccumulation of differentiated cells. ${ }^{17}$

Overproduction of the bot-2 protein in ransgenic mice provided evidence for the tumorigenic potential of these products in that they prevented cell death, demonstrated by prolonged cell survival and accumulation of cells. ${ }^{18}$ 
BCC is a malignant tumor, which rarely metastasizes, composed of cells similar to those in the basal cell layer of the epidermis and its appendages. ${ }^{19}$ Prominent cell death is suggested as an explanation for the clinically slow growth rate. ${ }^{713.19}$ Our immunohistochemical study of BCC using a monoclonal anti-bcl-2 antibody revealed that all tumors ( 15 frozen, 5 formalin samples) were $b c t-2$ positive which would support the hypothesis that BCCs originate from cells from the basal layer of the epidermis. The prominent $b c l-2$ expression of BCC tumor cells suggests also that inhibition of programmed cell death occurs, and would argue against the suggestion that prominent cell death in BCCs accounts for their typically slow growth rate.

Possibly a BCC is a neoplastic transformation caused by cell survival, independent of cell proliferation. This hypothesis is supported by the following results. Triti. ated thymidine labeling studies suggest that only a small percentage of the total cumor volume is actively proliferating. ${ }^{4}$ A study with the proliferation-associated Ki-67 antigen displayed Ki-67 reactivity either to the nuclei of three to five rows of peripheral cells, or to nuclei scattered in the central as well as in the peripheral parts of the tumor strands. ${ }^{20}$ Activated ras-oncogenes, which are related to increased cellular proliferation, are rare events in human non-melanoma skin cancer and it seems unlikely that mutational activation of ras genes is a common feature responsible for the induction of $\mathrm{BCC} .^{21}$ In $\mathrm{BCC}$ an aberrant expression of $p 53$ protein has been reported. ${ }^{22}$ The wild type $p 53$ gene is located on chromosome $17 \mathrm{p}$ and functions as a tumor suppressor gene by accing like a brake on tumor growth to allow optimal repair of damaged DNA. It is suggested that if this repair is not succesfull the $p 53$ gene induces apoptosis. The mutant version of $p 53$ is possibly acting similar to $b c t-2$ in blocking apoptosis. ${ }^{23}$

It is interesting to speculate that BCC is a result of increased cell survival, since some authors suggest that inhibition of programmed cell death may lead to neoplastic growth at slower rates than found with growth induced by oncogenes that act by stimulating cell proliferation. ${ }^{24}$

$S C C$ is a malignant tumor arising from the suprabasal keratinocytes of the epidermis and its cells show variable degrees of maturation and keratin formation. As mentioned before bol-2 is detectable in the basal cells of the epidermis, but not in the suprabasally located differentiated keratinocytes. There is evidence that in SCC in-situ of the skin increased cell proliferation is present. ${ }^{25}$ Our findings of absent $b c k-2$ staining in SCC of the skin suggest that increased proliferation rather than decreased cell death attributes to tumorigenesis in this type of skin cancer. In conclusion, the expression of the apoptosis-suppressing protein bcl-2 together with the absence of activated. ras-oncogenes related to cell proliferation and the small percentage of actively proliferating rumor cells, support the concept that $\mathrm{BCC}$ is a neoplastic transformation caused by extended cell survival. Ncoplastic 
growth as a consequence of extended cell survival instead of cell proliferation could porsibly be a new explanation for the typical slow growth rate of $\mathrm{BCC}$.

\section{Acknowledgments}

We thank Miss Margriet Pijls, Miss Annick Moors and Mr Sjaak Joosten for their technical assistance.

\section{References}

1. Epstein JH. Photocarcinogenesis, skin cancer, and aging. J Am Acad Dermatol $1983 ; 9: 487-502$.

2. Novick NL, Kest E, Gordon M. Advances in the biology and carcinogenesis of basal cell carcinoma. NY State J Med 1988;88:367-70.

3. Heenan M, Galand P. Decreased rate of DNA-chain growth in human basal cell carcinoma. Nature 1980;285:265-7.

4. Grimwood RE, Ferris CF, Mercill DB, Huff JC. Proliferating cells of human basal cell carcinoma are located on the periphery of tumor nodules. J Invest Dermatol $1986 ; 86: 191-4$.

5. Hunt MI, Halliday GM, Weedon D, et al. Regression in basal cell carcinoma: an immunohistochemical analysis. Br I Dermatol 1994;130:1-8.

6. Baum HP, Meurer I, Theobald A, Schmid Th. Proliferationssteuerung und ausbildung fraktaler wachstumsmuster in basaliomen. Akt Dermatol 1993:19:51-5.

7. Kerr JFR, Searle J. A suggested explanation for the paradoxically slow growth rate of basal cell carcinoma that contain numerous mitotic figures. J Pathol 1972;107:41-4.

8. Boyd JA, Barrett JC. Genetic and cellular basis of multistep carcinogenesis. Pharmacol Ther 1990;46:469-86.

9. Bishop JM. The molucular genetics of cancer. Science 1987;235:305-11.

10. Williams GT. Programmed cell death: apoptosis and oncogenesis. Cell 1991;65: $1097-8$.

11. Tsujimoto $Y$, Cossman J, Jaffe E, Croce CM. Involvement of the bct-2 gene in human follicular lymphoma. Science 1985;228:1440-3.

12. Lu QL, Poulsom R, Wong L, Hanby AM. Bit-2 expression in adult and embryonic non-haemaropoieric tissues. J Pathol 1993:169:431-7.

13. Curson C, Weedon D. Spontaneous regression in basal cell carcinomas. J Cutan Path 1979;6:432-7.

14. Kerr JFR. Willie AH, Currie AR. Apoptosis: A basic biological phenomenon with wide-ranging implications in rissue kinerics. Br I Cancer 1972;26:239-57.

15. Cohen JJ. Apoptosis. Inmunology Today 1993;14:126-30. 
16. Hockenberry DM, Nunez $\mathrm{C}$, Milliman $\mathrm{C}$, et al. $B$ d 2 is an inner mitochondrial prorein that blocks programmed cell death. Nature 1990,348:334-6.

17. Korsmeyer SJ bot-2 initiates a new category of oncogenes: Regulators of cell dearh. Blood 1992:80:879.86.

18. McDonnell T], Deane M, Platt FM, et al. Bcl-2-immunoglobulin transgenic mice demonstrate extended B cell survival and follicular lymphoproliferation. Cell 1989; $57 \% 79-88$.

19. Miller SJ. Biology of basal cell carcinoma (part 1). I Am Acad Dermatol 1991;24: 1-13.

20. Baum HP, Meurer I, Unteregger G. Ki-67 antigen expression and growth pattern of basal cell carcinomas. Arch Dermacol Res 1993:285:291-5.

21. Campbell C, Quinn AG, Rees JL. Codon 12 Harvey-ras mutations are rare events in non-melanoma human skin cancer. Br J Dermatol 1993;128:111-4.

22. Rady P, Scinicariello F, Wagner RF, Tyring SK. 53 mutarions in basal cell carcinomas. Cancer Research 1992;52:3804-6.

23. Marx J. Cell death studies yield cancer clues. Science 1993;259:760-1.

24. Pezzella F, Turley $\mathrm{H}, \mathbb{K} u z u$, et al. $B d-2$ protein in non-small-cell lung carcinoma. N Engl I Med 1993;329:690-4.

25. Penneys NS, Bogaert M, Serfling U, Sisto M. PCNA expression in cutaneous keratinous neoplasms and verruca vulgaris. Am J Parhol 1992;141:139-42. 

Chapter 5

Transforming growth factor-beta and bcl-2 distribution patterns distinguish trichoepithelioma from basal cell carcinoma

M.E.J.M. Verhaegh, I.W. Arends, I.M.L. Majoie,

R. Hoekzema, H.A.M. Neumann 


\section{Summary}

Trichoepithelioma (TE) and basal cell carcinoma (BCC) have many features in common both dinically and histologically. Despite these many similarities TE and BCC represent different biological entities.

Recently, $\mathrm{bCl}-2$ and $\mathrm{CD} 34$ have been reported as reliable markers in distinguishing the two types of tumor. TGF- $\beta$, a multifunctional regulator of both cell growth and differ entiation. was evaluated in this study. The immunohistochemical expression of TGF $\beta$ was compared with the distribution patterns of bd-2 and CD34 in 5 BCCS, 5 TEs and 7 borderline cases. All 5 TEs showed a diffuse cytoplasmic staining of tumor cells for $T G F-\beta$, whereas 4 of $5 \mathrm{BCC}$ were $T G F-\beta$ negative. Of the 7 equivocal cases of TE/BCC. 5 tumors demonstrated TGF- $\beta$ positivity in combination with negative bcl-2 staining corresponding to TE. The remaining 2 cases demonstrated the opposite staining pattern, characteristic for BCC.

The TGF- $\beta$ staining pattern appears to be a helpful additional marker together with bc/ 2 in differentiating between trichoepitheliama and BCC. The demonstrated staiming differences may relate no the distinct origim and biological behaviour of the two tumors and may therefore be of value in subsequent patient management. 
Chapter 5 Transforming growth factor-bete and bel-2

\section{Introduction}

Trichoepitheliomas (TE) are benign tumors confined to the dermis and characterized by aggregates of neoplastic epithelial cells with limited follicular differentiarion. ${ }^{1}$ Clinically, lesions appear as firm, skin colored nodules or papules mostly located on the face. Large lesions may be traversed by telangiectasias and sometimes ulcerate. This type of TE can be mistaken dinically for BCC. The histological distinction between TE and BCC also can be a difficult diagnostic dilemma, especially for the infundibulocystic type of $\mathrm{BCC}^{2}$ This distinction is importan because of the consequences for subsequent patient management. BCC displays a much more agressive tumor behaviour than TE, and should be excised completely.

Recently, bcl-2 (B-cell leukemia/lymphoma-2) and CD34 expression have been reported to be of diagnostic help in differentiaring between TE and $\mathrm{BCC}^{3.4} B c t-2$ functions as a repressor of programmed cell death, and is described to be present in $\mathrm{BCC}$ but absent in TE by immunohistochemical analysis. CD34 expression was demonstrated in the peri-tumoral stromal cells of TE, whereas the adjacent stroma of BCC stained negarive. In addition to $b c t-2$ and CD34, we selected TGF- $\beta$ (Transforming Growth Factor- $\beta$ ) because of its pleiotropic effects on cellular differentiation and growth.

17 cases of TE/BCC were studied and the results of the hematoxylin-eosin stained histological sections compared with immunohistochemical analysis of consecutive sections stained for $T G F-\beta, b c l-2$ and $C D 34$.

The aim of this study was to find an addicional diagnostic tool to discriminate trichoepithelioma from $\mathrm{BCC}$. The possible relation of our findings to the different biological characteristics of the two entities is discussed.

\section{Material and methods}

5 cases of unequivocal TE and 5 of nodular type BCC diagnosed histologically by the hospital parhologist in charge were obtained from the files of the department of Pathology, Academic Hospital Maastricht. An additional 7 borderline cases, i.e. tumors in which reliable discrimination between TE and BCC on routine histologic grounds was found to be difficult by the pathologist in charge, were selected too. Next, the total of 17 cases of TE and/or $\mathrm{BCC}$ were reviewed randomly by three dermatopathologists (A.V., M.D., R.H.). 10 cases were unequivocally diagnosed as $\mathrm{BCC}(\mathrm{n}=5)$ or TE $(\mathrm{n}=5)$ by all three pathologists. The remaining 7 cases, corresponding to the original 7 borderline cases, were equivocally classified as either BCC or TE. Histologic criteria included the presence or absence of epidermal connections, ulceration, significant inflammatory response, tumor-stromal clefits, 
Table l, Clincal feamres of 5 8CCs, 5 te, and 7 borderline cases

\begin{tabular}{|c|c|c|c|c|}
\hline Pat no. & Age: & $\mathrm{sex}$ & Site & Rentarks \\
\hline 1 & 82 & $M$ & back & \\
\hline 2 & 67 & $M$ & temple & \\
\hline 3 & 64 & $M$ & temple & $B C C 4 x$ \\
\hline 4 & 49 & $\mathbf{F}$ & nose & \\
\hline 5 & 45 & F & forehead & $8 C C 2 \times s C$ \\
\hline 6 & 53 & $F$ & nerk & \\
\hline 7 & 59 & I & nose & \\
\hline 8 & 59 & F & upper lip & $B C E 3 x$ \\
\hline 9 & 51 & $\mathrm{M}$ & eyebrom & \\
\hline 10. & 67 & $\mathrm{M}$ & nose & \\
\hline 11. & 33 & M & lorehead & \\
\hline 12 & 59 & F & cheek & \\
\hline 13 & 50 & f & eyelld & Melanoma \\
\hline 14 & 51 & 1 & nase & \\
\hline 15 & 61 & M & eyelld & $\mathrm{BCC} 2 \times$ \\
\hline 16. & 76 & f & nose & BCC $3 x$ \\
\hline 17. & 69 & $f$ & chin & \\
\hline
\end{tabular}

sce Squamous cell carcinoma

Table II. Incidence of histologic features of the unequivocal 5 BCCS (tumor no 15 ) and 5 TE (tumor no. 6 - 10), and the 7 equivocal cases of BCCAE (tumor no, 11 17), all classified on mor phologlal grounds Followed by the classified 5 TEs (tumor no 1 1-15) and 2 BCCs (tumor no. $16-17)$ by immunohistochemical analys is of the equivacal group.

\begin{tabular}{|c|c|c|c|c|}
\hline Festure & $\begin{array}{l}3 C \mathrm{C} \\
191 \\
\mathrm{~N}=5\end{array}$ & $\begin{array}{l}T E \\
(\%) \\
N=5\end{array}$ & $\begin{array}{l}\mathrm{BC} / \mathrm{H} \\
(\%))^{\prime}\end{array}$ & $\begin{array}{l}\mathrm{TE} \\
\mathrm{N} \% \mathrm{5}\end{array}$ \\
\hline Eplormal conneclons & 80 & 27 & 43 & 60 \\
\hline Tumorstromal defts & 80 & 0 & 48 & 47 \\
\hline Inflanmatony response & 80 & 0 & 29 & 20 \\
\hline Mitotic figures & 60 & 47 & 27 & 20 \\
\hline Fliotic stroma & 27 & 100 & 62 & 67 \\
\hline Infundibunlar cysts & 13 & 87 & 67 & 60 \\
\hline Follicular cifferentiation & 7 & 93. & 52 & 47 \\
\hline
\end{tabular}


Table II. Results of the roukine histological sections diagnoses of the three dermato pathologists on morphological grounds), immunohistodhemic al analysis and final diagnosis of $5 \mathrm{BCC}$. 5 TEs and 7 equivocal cases of BCCME.

\begin{tabular}{|c|c|c|c|c|c|}
\hline Junor no. & Routine histolagy & JGF $P$ & $\mathrm{BCL}_{2}$ & $\mathrm{CD} 34$ & Final Diagnosis \\
\hline 1 & $\mathrm{BCCBCCBCC}$ & 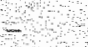 & + & + & $\mathrm{BCC}$ \\
\hline 2 & $\mathrm{BCC} B C C \mathrm{BCC}$ & 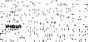 & + & + & $\mathrm{BCC}$ \\
\hline 3 & $\mathrm{BCC} \mathrm{BCC}-\mathrm{BCC}$ & - & + & + & $\mathrm{BCC}$ \\
\hline 4 & $\mathrm{BCC} B C C \mathrm{BCC}$ & + & + & + & $\mathrm{BCC}$ \\
\hline 5 & $\mathrm{BCC}-\mathrm{BCC} B C C$ & + & + & $=$ & $\mathrm{BCC}$ \\
\hline 6 & $\mathrm{TE}-\mathrm{TE}-\mathrm{IE}$ & + & + & + & $7 E$ \\
\hline 7 & TEALIE & + & $=$ & + & TE \\
\hline 8 & JE-TE-TE & + & 4 & + & TE \\
\hline 9 & TEJIE-IE & $1+$ & +1 & 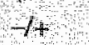 & $\mathrm{BCC}$ \\
\hline 10 & AE-TE-TE & + & 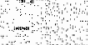 & ND & TE \\
\hline 11 & BCCAE IE & + & 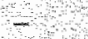 & + & TE \\
\hline 12 & BCCTE-TE & + & - & + & $\mathrm{TE}$ \\
\hline 13 & $\mathrm{BCCTCBCC}$ & 4 & 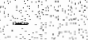 & + & $\mathrm{TE}$ \\
\hline 14 & BCC IE-TE & + & -3 & NO & TE \\
\hline 15 & $B C C] E B C C$ & + & 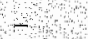 & + & TE \\
\hline 16 & $\mathrm{BCCTCBCC}$ & - & + & 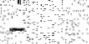 & $\mathrm{BCC}$ \\
\hline 17 & $\mathrm{TE}-\mathrm{TE}-\mathrm{BCC}$ & & + & 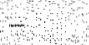 & $\mathrm{BCC}$ \\
\hline
\end{tabular}

mitotic figures, fibrotic stroma, infundibular cysts and follicular differentiation in the manner of follicular germs and papillae. After review of routine histologic sections additional $5 \mu \mathrm{m}$-paraffin sections were cut and immunohistochemical anallysis was performed essentially as described previously, using an avidinbiotin-peroxidase technique with $3,3^{\prime}$ diaminobenzidine (DAB) as the chromogen and $1 \%$ haematoxylin as the counterstain. $3,9,13$ Primary antibodies were the following: bel-2 (clone 124, DAKO, Glostrup, Denmark), CD34 (anti-HPCA-1, Becton Dickinson, Erembodegem-Aalst, Belgium) and TGF- $\beta$ (code 1835-01; anti-TGF- $\beta_{1},-\beta_{2},-\beta_{3}$, Genzyme, Cambridge, USA). Negative controls were treated as above, omitting the primary antibody incubation step.

\section{Results}

The clinical features of this series of TE/BCC are outlined in Table I. The patients ( 10 females, 7 males) ranged in age from 33-82 years (mean 57). All lesions except one were located in the head-neck region and existed for at least one year without 


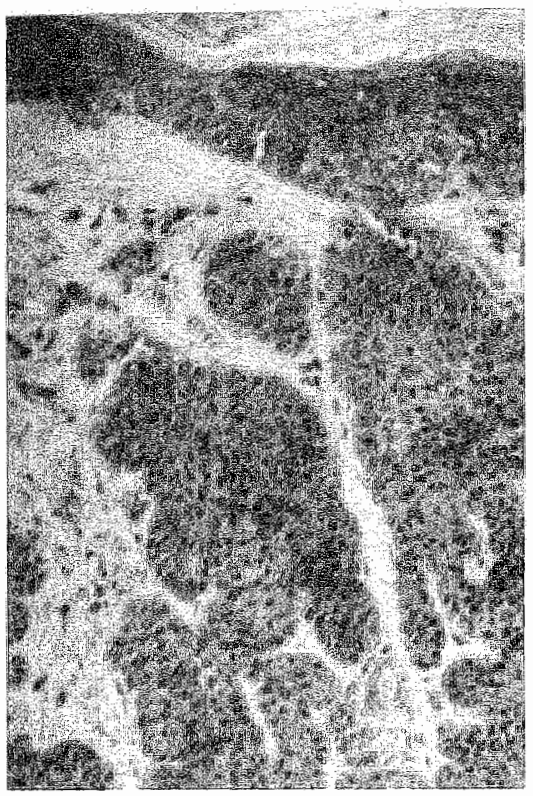

Figure 1a. Tumor no.7 demonstrating positive cytoplasmic staining of tumor cells for TGF- $\beta_{\text {, characteristic of TE. (magnification } x}$ 75).

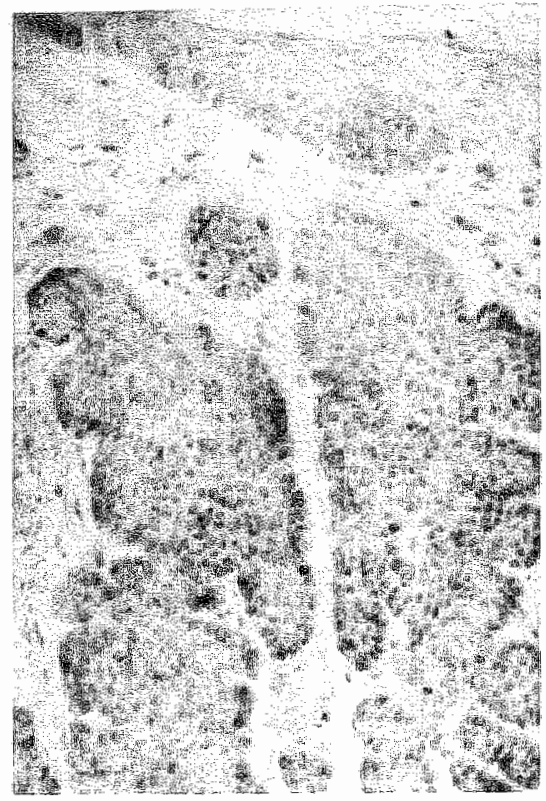

Figure 1b. Tumor no. 7 with positive $b c l-2$ staining only at the periphery of tumor nests, characteristic of TE. (magnification $x$ $75)$

recent changes. All tumors were solitairy except case no.6. The therapy of choice was excision in all cases. The duration of follow up ranged from 2-4 years. Until now, no recurrences of tumor have occurred. Six patients either had a history of skin cancer, or developed skin cancer at other sites afterwards.

The morphologic features of the $5 \mathrm{BCCs}, 5 \mathrm{TEs}$ and 7 equivocal cases of TE/BCC reviewed by three different dermatopathologists are compared in Table II. Column 4 and 5 contain the histological features of the 7 borderline cases after their classification as either TE $(n=5)$ or BCC $(n=2)$ by immunohistochemistry. The immunohistochemical results are presented in Table III.

TGF- $\beta$ : A diffuse homogeneous cytoplasmic staining of tumor cells throughout the tumor nests was considered positive (Fig. Ia). All 5 TEs, 1 BCC and 5 equivocal cases were TGF- $\beta$ positive. Tumor no.9, diagnosed as a TE on routine histologic grounds, displayed a dual staining pattern with positive and negative areas in the same cumor lobules (Fig.2a). In this particular tumor $T G F-\beta$ expression was restricted to areas of follicular differentiation and infundibulocystic structures. The remaining cases were unreactive for $T G F-\beta$ or showed faint staining of spindle/squamoid cells in the centre of some tumor islands (Fig. 3a). The peritumoral 


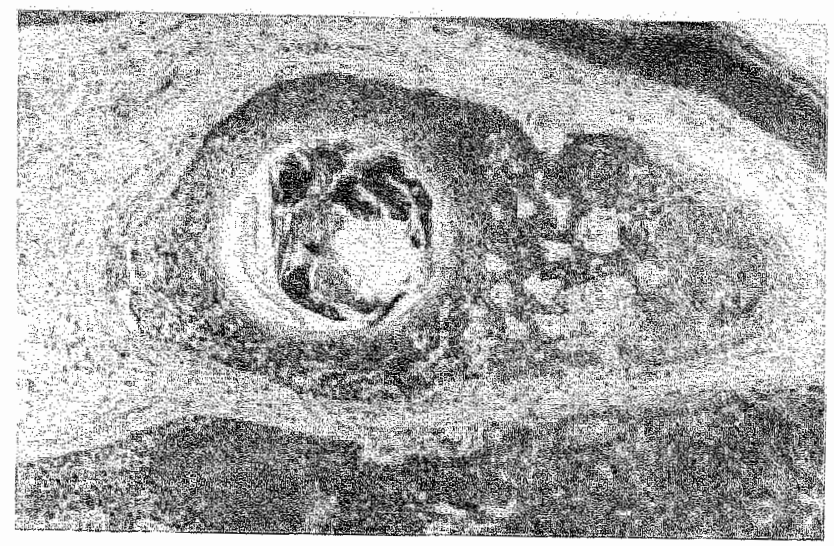

Figure 2a. Tumor no.9 with markedly positive rGFu staining of areass of follicular differentiation and infundibulowcystic structures. (magnification $\times 75$ ).

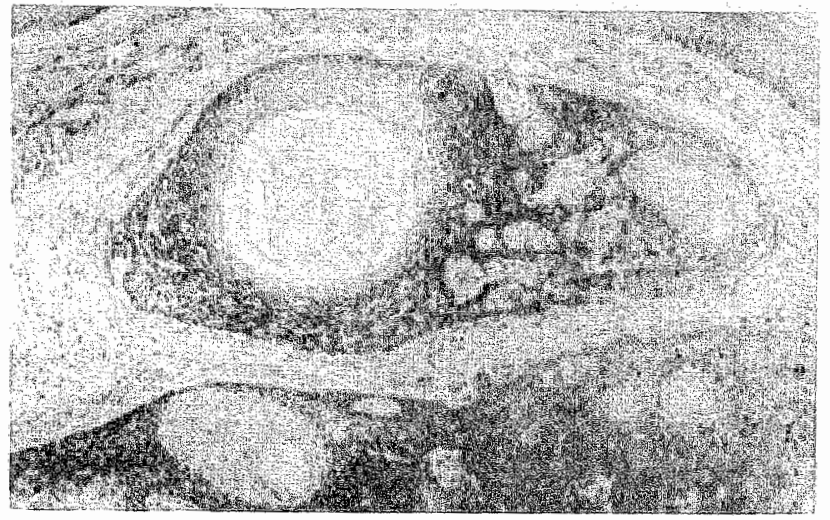

Figure $2 \mathrm{~b}$. Tumor no.9 with positive bcl-z staining of tumor cels throughout the tumor nests except areas of follicular differentiation and infundibulo-cystic structures. (magnification $\times 75$ ).

stroma of both BCC and TE was largely negative. Positive staining was also noted in the cytoplasm of suprabasal normal keratinocyres and in endorhelial cells. Bcl-2: A fine granular cytoplasmic staining of tumor cells throughout the tumor nests with $6 \mathrm{cl}-2$ was considered positive (Fig.3b). All 5 BCCs, 2 TE's and 2 equivocal cases were $b c t-2$ positive. In contrast with $T G F-\beta$ staining, tumor no. 9 showed positive homogenous cytoplasmic bct-2 staining of tumor cells throughout the tumor nests except for the areas of follicular differentiation and infundibulo-cystic structures (Fig.2b). Tumor no.6, also diagnosed as a TE, displayed positive bct-2 staining of all rumor cells, but also of the entïre epidermis and 


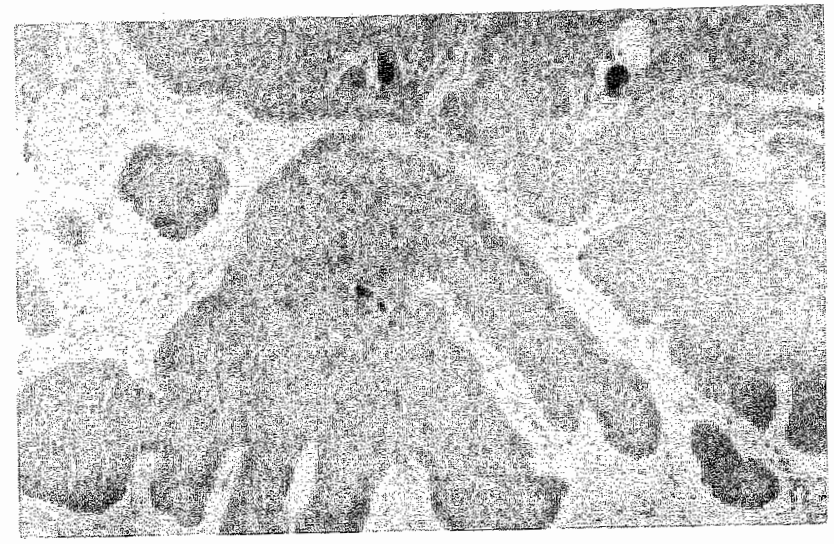

Figure 3a. Tumor no. 16 with negative TGF- $\beta$ staining of tumor cells, characteristic of $B C C$. (magnification $\times 75)$.

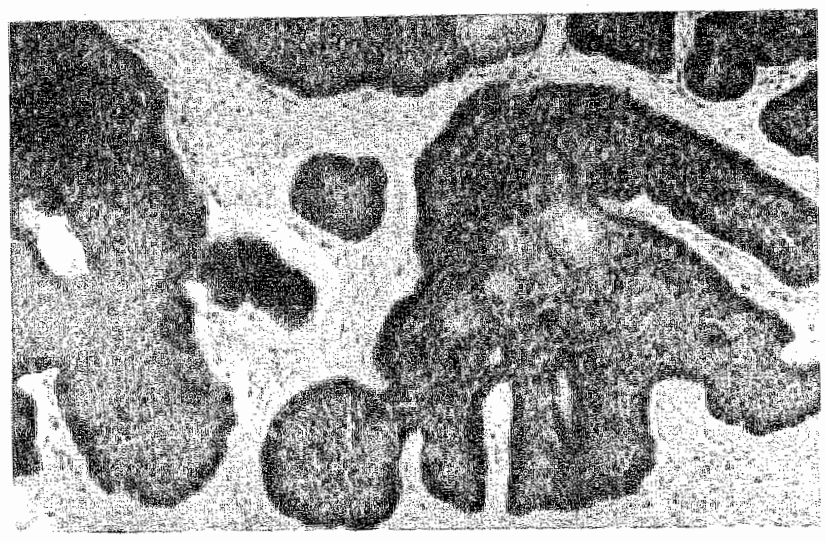

Figure $3 \mathrm{~b}$. Tumor no. 16 demonstrating prominent homogeneous cytoplasmic bcl-2 expression of tumor cells, characteristic of $B C C$. (magnification $\times 75$ ).

follicular strucures. In the remaining cases staining was limited to the outermost layer of the proliferations (Fig. 1 b). As in normal dermis, a few dermal perivascular: lymphocytes were present in all cases of TE. These lymphocytes as well as the lymphocytic infitrates surrounding $B B C s$ together with basal keratinocytes of the epidermis served as internal positive controls for the antibody against $6 c t-2$. CD34: Expression of the CD34 antigen by the mesenchymal cells adjacent to the tumor islands was considered positive. 3 TE's and 4 equivocal cases were CD34 positive. 2 BCCs (rumor no.1 and 2) and one TE (rumor no.9) displayed staining in one area and absence of staining in another. In the remaining cases there was a 
Chapter $5 \mid$ Transforming growth factor-beta and bcl-2

buffer zone of negatively stained cells separating the epichelial islands from the CD34-positive mesenchymal cells. In all sections there was CD34 positrity of endothelial cells.

\section{Discussion}

Precise differentiation between TE and BCC is important since their treatment and prognosis are different. Ulceration, tumor-stromal clefts, "inflammatory response and mitosis are histologic fearures of $\mathrm{BCC}$, whereas papillary mesenchymal bodies, fibrotic stroma, infundibulo-cystic structures containing cornified cells, and follicular differentiation in the form of germs and papillae are considered characteristic of TE ${ }^{5,6}$ In general, the assessment of histologic features in 5 BCCs and 5 TEs by our panel of dermatopathologists, as depicted in Table I, proved to be in accordance with the above-mentioned diagnostic criteria.

Unfortunately the group of equivocal cases of $\mathrm{BCC} / \mathrm{TE}$ often displays an inconsistent distribution of these features as demonstrated in column 3 of Table I. In these cases a clear diagnosis cannot be made in spite of detailed clinical information and routine histopathology. This observation is supported by the clata in column 4 and 5 of Table II. After classifying the 7 borderline cases based on immunohistochemistry the 5 TEs and $2 \mathrm{BCC}$ still display a non-specific partern of histological features.

Recently $6 c-2$ and $C D 34$ were introduced as helpful and reliable immunohistochemical markers to discinguish TE from BCC. 3.4 The proto-oncogene $b c t-2$ encodes a protein which inhibits programmed cell death (apoptosis), and is expressed in normal basal keratinocytes but not in the superficial layers. ${ }^{78}$ Bcl-2 expression has been demonstrated intracellularly in a wide variety of neoplasms, including BCC." Smoller et al, who examined $10 \mathrm{BCCs}$ and 10 "TEs for $b c \mathrm{l}-2$, found all BCCs positive with prominent homogenous cytoplasmic staining throughout the lesions, whereas in TEs, wichout exception, staining of tumor cells was limited to the outermast basaloid cells. ${ }^{4}$ Although we were able to confirm these results in general, we cannot explain the strong diffuse staining for $b c l-2$ in tumor no.6, diagnosed as TE.

CD34, a 115-kd glycoprotein, is present in mesenchymal cells locared around the middle portion of normal hair follicles. ${ }^{10,11}$ Since TEs are neoplasms with differentiation roward follicular epithelium, positive stroma staining around TE tumor nests was expected. Kirchmann er al observed strong peritumoral staining of CD34 in $16 \mathrm{TEs}$, but not in $19 \mathrm{BCCs} .{ }^{3}$ However, in our hands two out of five BCCs (tumors no. 1,2) displayed strong CD34 positivity of the immediate tumor stroma. 
TGF- $\beta$ is a multifunctional regulator of both cell growth and differentiation and has been shown to inhibit the growth of epithelial cells, stimulate mesenchymal cells and promote epithelial cell differentiation. ${ }^{12}$ Our results of TGF- $\beta$ staining in normal epidermis and in BCC tumor islands are in agreement with those of Stamp et al. ${ }^{13}$ However, we did not observe the abundant extracellular presence of TGF- $\beta$ in peritumoral stroma, reported by these authors in the sclerosing types of BCC. This is unlikely to be caused by our use of a different antibody, as our antibody recognizes both precursor (intracellular) and activated (extracellular) $T G F-\beta 1$ and $T G F-\beta 2$. Maybe it is due to the fact that we studied only nodular and not sclerosing $\mathrm{BCC}$.

To our knowledge the expression of TGF- $\beta$ by TE tumor cells presented in our study, has not been reported before. The combination of staining for $T G F-\beta$ and $b c l-2$ seems to be valuable in differentiating this neoplasm from BCC. In general, TE displayed TGF- $\beta$ positivity combined with negative $b c l-2$ staining whereas $\mathrm{BCC}$ expressed the opposite. This enabled us to classify the 7 equivocal cases of TELBCC (Table 2).

Glick et al studied $T G F-\beta 1$ and $T G F-\beta 2$ expression in murine skin and skin tumors. ${ }^{14}$ They showed that in the mouse TGF- $\beta$ expression and response are compartmentalized, and thar loss of TGF- $\beta$ in epidermis is linked to increased risk for malignant conversion. As discussed by these authors, loss of expression of TGF- $\beta$ from epidermal cells may be associated with increased proliferation and decreased apoptosis. If we extrapolate this to the human situation in BCC, loss of TGF- $\beta$ expression could be a second mechanism responsible for extended cell survival besides expression of $b c t-2$. Moreover, the absence of $T G F-\beta$ expression in BCC could be correlated with the apparent failure of the tumor cells to differentiate. One could speculare that the bol-2 positive/TGF- $\beta$ negarive cells in BCC are responsible for the biologically more agressive behaviour of these tumors, compared to the $b c /-2$ negarive/ TCF- $\beta$ positive cells in TE. So, tumors with a $b c t-2$ positive/ TGF- $\beta$ negative staining pattern possibly deserve a more agressive therapeutical approach.

The staining differences of $T G F-\beta$ and $b c-2$ in TE and BCC rogether with their possible relevance for tumor behaviour, are well demonstrated in tumor no.9. On routine hisrologic grounds three dermato-pathologists diagnosed this tumor as a $T E$, because of fearures of follicular differentiation, cornification, fibrotic stroma and absence of clefts and inflammatory cells. In retrospect, we believe tumor no.9 represents an infundibulocystic $\mathrm{BCC}$. This variant of $\mathrm{BCC}$ was described in 1990 by Walsh and Ackerman and recently discussed by De Eusebio er al. "1, In In general, the characteristic features of infundibulocystic BCC they reported are in accordance with our cumor no.9: (1) continuity of the neoplastic cells with infundibula, (2) 
scant stroma, (3) follicular germs devoid of associated follicular papillae, (4) lack of differentiation toward outer sheath, inner sheath, or hair and (5) presence of neoplastic cells in mitosis. So, based on morphological grounds tumor no 9 can be diagnosed as an infundibulocystic BCC and not a TE. This is in agreement with the observation that most of the tumor cells stained $b c t-2$ positive/ TGF- $\beta$ negative, except for areas of follicular differentiation and infundibulo-cystic structures, in which the opposite staining pattern was observed. More cases of neoplasms with follicular differentiation and a differential diagnosis of TE versus infundibulocystic BCC have to be studied, in order to determine the exact additional walue of immunohistochemistry over morphological features in these particular cases.

In conclusion, the clinical and histological distinction between TE and BCC sometimes proves to be a diagnostic dilemma. Staining for TGF $\beta$, especially in combination with bo $t-2$, appears to be of additional but not final value in differentiating both tumors.

\section{Acknowledgments}

We thank dermatopathologists A.Vermeulen, M.Daemen and R.Hulsmans for reviewing the routine histological sections, and Miss Margriet Pijls and Miss Annick Moors for their technical assistance.

\section{References}

1. Ackerman AB, De Viragh PA, Chongchitnant N. Neoplasms with follicular differentiation. Philadelphia: Lea and Febiger, 1993:425-58.

2. Walsh $\mathbb{N}$, Ackerman AB. Infundibulocystic basal cell carcinoma: a newly described variant. Modern Pathol 1990;3:599-608.

3. Kirchmann TT, Prieto VG, Smoller BR. CD34 staining patrem discinguishes batall cell carcinoma from trichoepithelioma. Arch Demarol 1994:130:589-92.

4. Smollex BR, van de Rijn M, Lebrun D, Warnke RA. Bct-2 expression reliably distinguishes trichoepitheliomas from basal cell carcinomas. Br J Dematol 1994;131: 28-31.

5. Brooke JD, Fitpatrick JE, Golitz LE. Papillary mesenchynal bodies: a histologic finding usefull in differentiacing trichoepitheliomas from basal cell carcinomas. I Am Acad Dermatol 1989;21:523-8.

6. Ackerman AB, Mendonça AMN, Guo Y. Differential diagnosis in dematopathology I. Philadelphia: Lea and Febiger, 1992:130-3.

7. Hockenbery DM, Nuñez G, Milliman C, Schreiber RD, Korsmeyer S1. Brt-2 is an inner mitochondrial protein that blocks programmed cell death. Nature 1990;348: $33.4-6$. 
8. Hockenbery DM, Olrvai ZN, Yin XM, Milliman CL, Korsmeyer SI. BCL-2 functions in an antioxidant pathway to prewent apoptosis. Cell 1993;75:241-51.

9. Verhaegh MEJM, Sanders CJG, Arends JW, Neumann HAM. Expression of the apoptosis-suppressing protein bol-2 in non-melanoma skin cancer. Br ] Dermatol $1995: 132: 740-4$

10. Andrews $\mathrm{RG}$, Singer JW, Bernstein ID. Monodonal antibody 12.8 recognizes a 115 kd molecule present on both unipotent and mulriporent hematopoietic colory forming cells and ther precursors. Blood 1986;67:842-5.

11. Nickoloff BJ. The human progenitor cell antigen (CD34) is localized on endothelial cells, dermal dendritic cellis, and perifollicular cells in formalin-fixed normal skin, and on proliferating endothelial cells and stromal spindle-shaped cells in Kaposi's sarcoma. Arch Dermatol 1991;127:523-9.

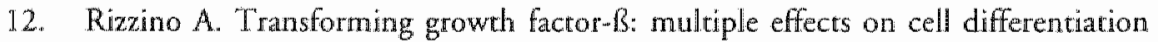
and extracellular matrices. Dev Biol 1988;130:411-22.

13. Stamp GWH, Nasim M, Cardillo M, Sudhindra SG, Lalani EN, Pignarelli $M$. Transforming growth factor- $\beta$ distribution in basal cell carcinomas: relationship to proliferation index. Br J Dermatol 1993;129:57-64.

14. Glick $A B$, Kulkarni $A B$, Tennenbaum $T$, et al. Loss of expression of transforming growth factor $\beta$ in skin and skin tumors is associated with hyperproliferation and a high risk for malignant conversion. Proc Natl Acad Sci 1993;90:6067-80.

15. De Eusebio E, Yus ES, Bran EL, Rojo S, Rueda M, Del Cerro M. Infundibulacystic basaloid neoplasm. J Cutan Pathol 1996;23:147-50. 
Chapter 6

\section{Clinical and histological features of recurrent extensive basal cell carcinoma}

M.E.J.M. Verhaegh, F.W.G. Gruintjens, G.A.M. Krekels,

A.H.M. Vermeulen, H.A.M. Neumann

Submitted for publication 
Summary

Most basal cell carcinomas ( $B C$ C S) are small, siow growing, well defined lesions easily treated by various methods. On the other hand, there is also a group of aggressive BCCS characterized by extensive local invasion and disfigurement.

Possible risk factors, both clinically and histologically, were evaluated in a retrospective study of 72 recurrent extensive BCCS. Most BCC5 were initially treated by surgical excision. The recurrent tumors were treated by means of Mohs' micrographic surgery. The mean preoperative tumor size in our study was $2.1 \mathrm{~cm}$. All 72 tumors except one were located in the face, of which the nasal-perinasal area was the most common site ( $51 \%$ ). In 33\% of the cases the histologic pattern displayed a mixture of solid and infiltrative components in the same tumor, $38 \%$ demonstrated a strictly nodular tumor growth, whereas $21 \%$ was of the infiltrative type.

Analysis of 72 recurrent extensive $B C C$ s demonstrated the following characteristics: mean lesion diameter $>2 \mathrm{~cm}$ and tumor location in the central $\mathrm{H}$ zone of the face. Besides confirming the documented aggressiveness of the morpheaform type BCC. we also demonstrated extensive tumor growth of both nodular and nodular-infiltrative type BCC. The perinasal area in particular was characterized by extensive vertical tumor expansion of the nodular/nodular-infiltrative tumor type. 
$\mathrm{BCC}$ is the most common malignancy in man, predominantly found on sunexposed areas. The incidence of $\mathrm{BCC}$ is rapidly increasing worldwide. In the Netherlands (15 million inhabirants), approximately $18.000 \mathrm{BCCs}$ were diagnosed in 1994 , with an expected increase of $2.700 \mathrm{BCCs}$ yearly. ${ }^{1}$

$\mathrm{BCC}$ can be categorized into subtypes morphologically and histologically. A convenient clinical classification includes superficial, nodulo-ulcerative, morphea-like or fibrosing, and pigmented types. In large studies, 45-60 percent are noduloulcerative, 15-35 percent superficial, 1-2 percent pigmented, and the remainder 4 to 17 percent morpheaform. ${ }^{2}$

Histologically BCCs can be divided into two groups: undifferentiated and differentiated tumors. Keratotic BCC and adenoid BCC are examples of the latter group. BCCs showing no differentiation can be subdivided into multifocal superficial, nodular, micronodular, infiltrating (nonsclerosing vs. sclerosing), basosquamous and pigmented type. ${ }^{3}$

Most BCCs are slow growing, relatively non-aggressive tumors that are treated by various methods of treatment like conventional surgery, curertage and electrodesiccation, cryotherapy and radiotherapy. A minority of tumors, however, displays a more aggressive biological behaviour, with extensive local tissue destruction, multiple recurrences or, in rare cases, even metastasis.

Aggressive-growth $\mathrm{BCC}$ (AG-BCC) has been variously defined and studied previously by other investigators. ${ }^{4,5} \mathrm{AG}-\mathrm{BCCs}$ are a group of clinically and histologically aggressive cumors. This group includes infiltrating and recurrent BCCs. Other general criteria used to identify AG-BCC include, (1) patients under 35 years of age, especially women, (2) BCCs localized in the center of the face, and (3) increasing lesion diameter $(>2 \mathrm{~cm}) \cdot{ }^{6-8}$ Inadequate treatment of AG-BCC will ultimately lead to recurrence and reconstructive challenges that possibly could have been avoided by recognizing this type of tumor initially.

Mohs' micrographic surgery (MMS), a method that provides complete microscopic control of the excision, seems particularly useful for managing these AGBCCs.

MMS is a standard rourine treatment for different types of BCC in the United States of America." In Europe, where MMS is less widely available, only AG$\mathrm{BCCs}$ are treated by this technique.

In this study we retrospectively evaluated a selected group of recurrent extensive $\mathrm{BCC}$ treated by MMS, in order to derermine their clinical and histological parameters. 


\section{Patients and methods}

Of a total of 371 cases of BCCs treated by MMS in the period $1992-1996$ at the dermatology department of the University Hospital Maastricht, 72 cases were selected. All selecred cases were recurrent tumors. A recurrence was defined as the reappearance of a $\mathrm{BCC}$ within or contiguous to the scar resulting from the initial atrempt at definitive treatment. The previous treatment modalities utilized for the recurrent tumors are summarized in Table I, categorized by tumor type. Fourcytwo $(58 \%)$ recurrent tumors had been previously treated once, fifteen cumors (21\%) twice, seven tumors (10\%) three times, three tumors (4\%) four times and five tumors $(7 \%)$ were prewiously treated at least five times.

Besides the recurrence status, we also selected only those tumors that required at least three surgical Mohs stages before complete tumor removal was achieved. The minimum of three Mohs layers was chosen because of our specific interest regarding the histologic growth types of BCC and their subclinical horizontal and/or vertical extension pattern.

Next, all Mohs slides of each tumor were reviewed by at least rwo aurhors of this article. The histologic patterns of the BCCs were classified as follows: 1) nodular rype: circumscribed, well-defined islands of tumor cells in the dermis with typically prominent peripheral palisading and retraction clefts, 2) infiltrative type: irregular tumor islands predominantly arranged as elongared strands with spiking contours, with (infiltrative morphea-form BCC) or without (infiltrative nonmorphea-form BCC) fibrotic stromal response, 3) adenoid type: thin strands of basaloid cells in a reticulate pattern, surrounded by a mucinous stroma, 4) micronodular type: dispersed growth pattern with small nests without typically prominent peripheral palisading and retraction spaces, and 5) basosquamous type: composed of three types of cells: basaloid cells, squamoid cells and intermediate cells which resemble those seen in metatypical rumors. ${ }^{10}$ All cases were classified according to the direction of subclinical tumorspread by evaluating the Mohs mapping charts, in a prominent horizontal, a prominent vertical or an equal horizontal and vertical growth pattern, as demonstrated by Breuninger et al. ${ }^{11}$

The histologic subtypes and the pattern of subclinical horizontal and vertical extension were correlated with age (at the moment of operation) and sex of the parient, size of the tumor before surgery (largest diameter in $\mathrm{cm}$ ), size of the final defect (largest diameter in $\mathrm{cm}$ ), and the anatomic location of the tumor (according to the specific site codes of the New York University Medical Center, University Hospital, oncology section). 
Table I The various histological BCC ypes assaciated with their prevlous treat ment modality.

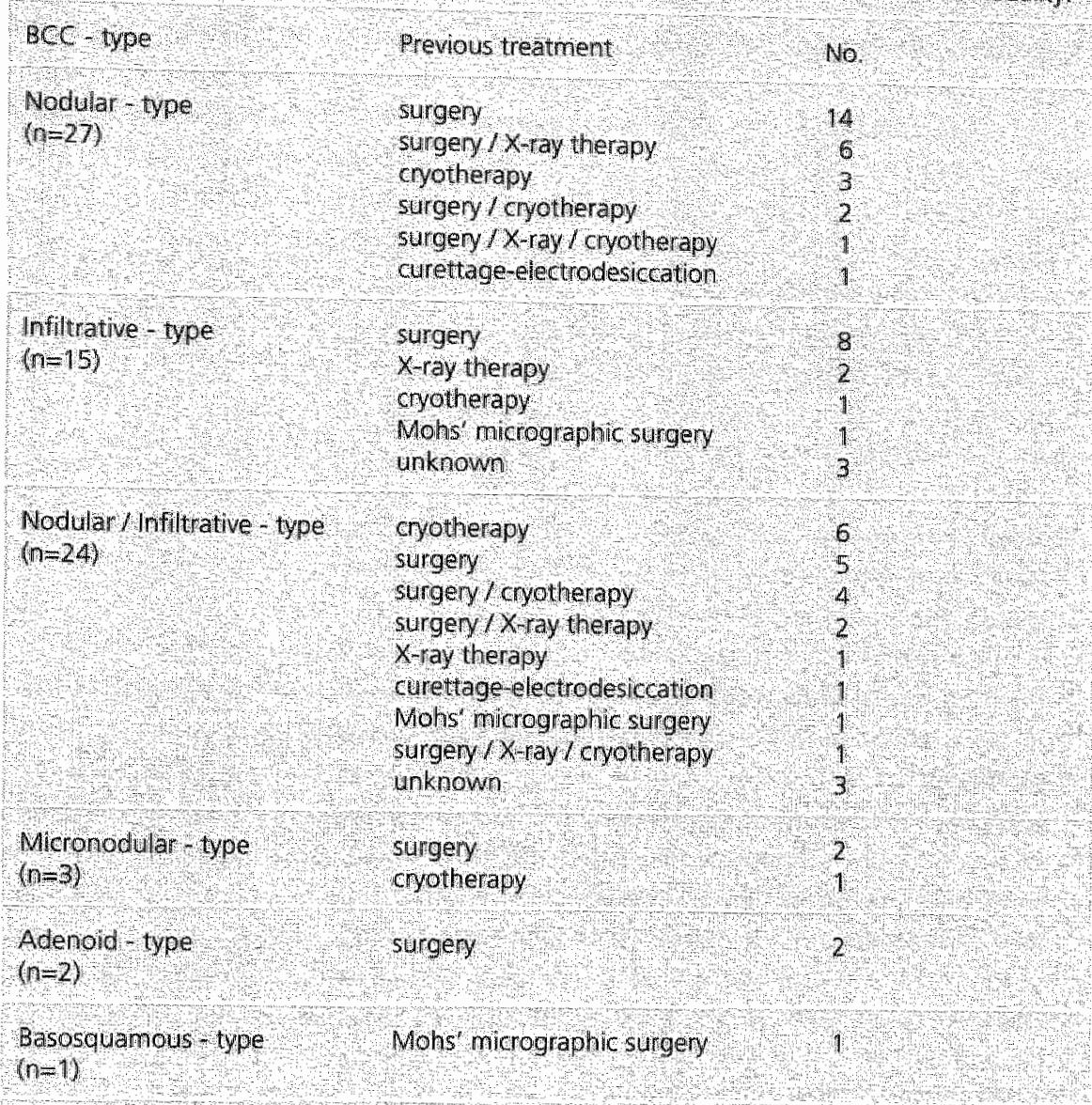

\section{Results}

Seventy-two recurrent BCCs were reevaluated. All selected tumors required at least three surgical stages of MMS. The number of surgical Mohs stages and frozen slides was 3-7 (mean 4.1) and 4.55 (mean 17.5) respectively. Fourty-four (61\%) of the parients were male between the ages of 43 and 86 years (mean, 68.2) and $28(39 \%)$ were fermale between 33 and 94 years old (mean, 66.9). The overall mean age was 67.7 years (Fig. 1).

of $56(78 \%)$ tumors pre- and post-operative measurements were available. The clinical pre-operative tumor size was $0.3-8.0 \mathrm{~cm}$ (mean $2.1 \mathrm{~cm}$ ). The final size of 
the Mohs surgical defect ranged in diameter from $1.0-11.5 \mathrm{~cm}$ (mean $3.8 \mathrm{~cm}$ ) (Fig. 2).

Fig. 3 shows the locations of the BCCs as seen in our study population. The most frequent location was the nose $(\mathrm{n}=24 ; 33 \%)$, followed by the forehead/temple $(\mathrm{n}=15 ; 21 \%)$, the alar base/nasal-labial groove $(\mathrm{n}=13 ; 18 \%)$, the periocular and canthi region $(n=7 ; 10 \%)$; the ear and pre/post auricular region $(n=6 ; 8 \%)$, the cheek $(n=4 ; 6 \%)$, the upper lip $(n=2 ; 3 \%)$, and the trunk $(n=1 ; 1 \%)$.

The following histologic patterns and their respective numbers and frequencies were observed: nodular type $(n=27 ; 38 \%)$, infiltrative type $(n=15 ; 21 \%)$, micronodular type $(n=3 ; 4 \%)$, adenoid type $(n=2 ; 3 \%)$, and basosquamous type $(n=1$; $1 \%$ ). In the remaining 24 cases (33\%) studied, circumscribed solid tumor masses of various sizes and shapes were observed in combination with deeply invading basalloid cells predominantly arranged as elongated strands, only a few layers thick with little or no palisading of the peripheral cells. Increase of stroma collagen or fibroblasts was not present (Fig.4). This 'mixed' tumor could be classified as nodular-infiltrating rype $\mathrm{BCC}$. ${ }^{2}$ In all these 24 nodular-infiltrative type $\mathrm{BCC}$ we compared the histopathological features from the center of the tumor with the horizontal and vertical tumor extensions. All cases demonstrated a shift from a circumscribed nodular growth pattern at the center of the tumor to a more infiltrative growth at the periphery, with extensions deep into the dermis, subcutaneous fat or muscle.

Fig. 5 shows the distribution of the different histologic types of BCC, correlated to the different anatomic locations. Both the nose and nasolabial region show a preference for the nodular and nodular-infiltrative type, whereas the forehead displays a preference for the infiltrative type.

Next, the subclinical growth pattern of different histologic subtypes of BCC is presented. Among the nodular BCC types, $56 \%$ of the cases displayed horizontal subclinical growth, 26\% vertical and $18 \%$ were characterized by both horizontal and vertical tumor extension. The infilrative and mixed nodular/infiltrative types displayed the following subclinical patterns: horizontal (40\%), vertical $(40 \%)$, horizontal/vertical $(20 \%)$, and horizontal $(33 \%)$, vertical $(25 \%)$, horizontal/vertical $(42 \%)$ respectively.

Fig.6 shows the different histologic subtypes with their corresponding subclinical outgrow pattern, related to different anatomic locations. The forehead in particular displays a horizontal growth pattern, whereas the nose is characterized by both horizontal and vertical extensions. The nasolabial area displays a striking pattern of vertical expansion. 


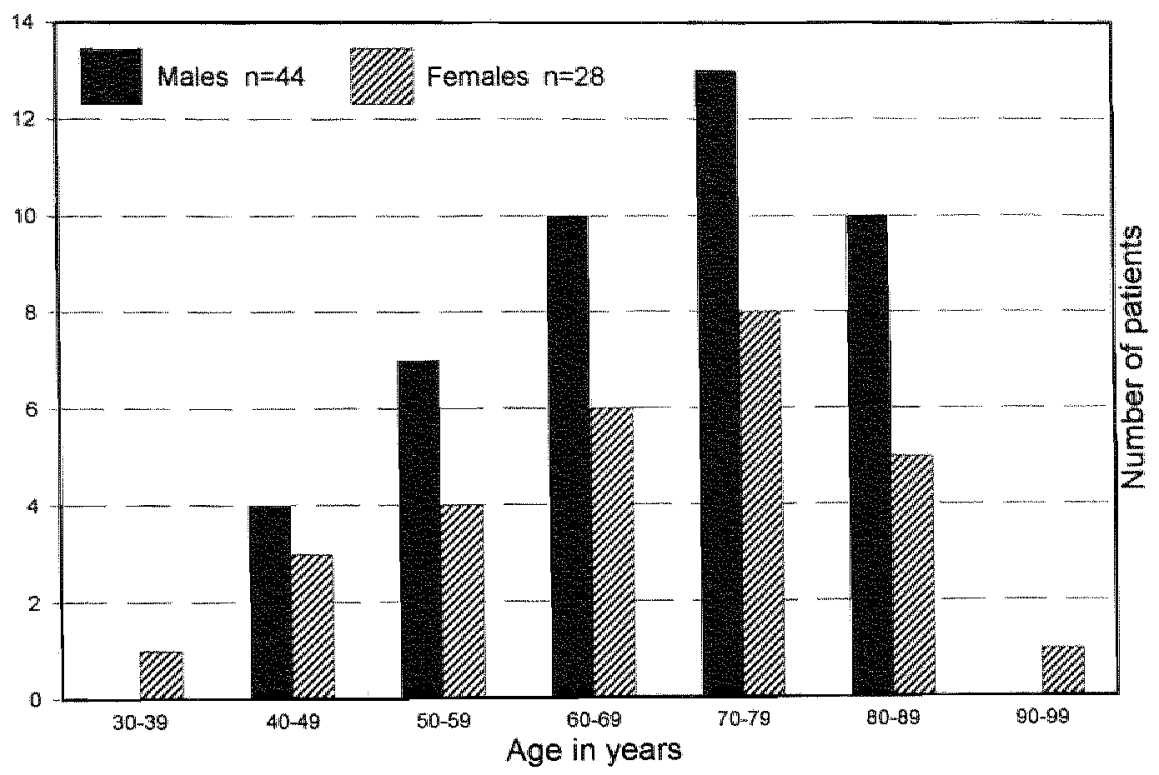

Figure 1. Patients with recurrent extensive BCC according to sex and age.

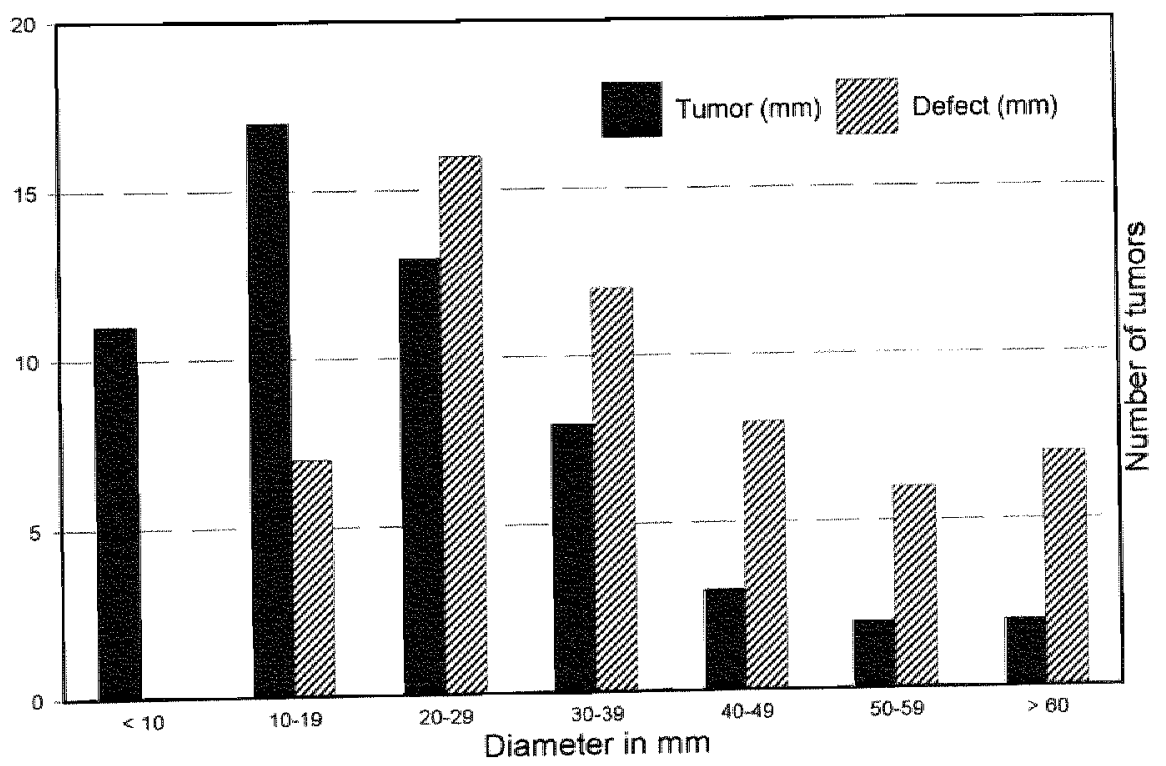

Figure 2. Pre-operative tumor size and post operative wound size $(n=56)$. 


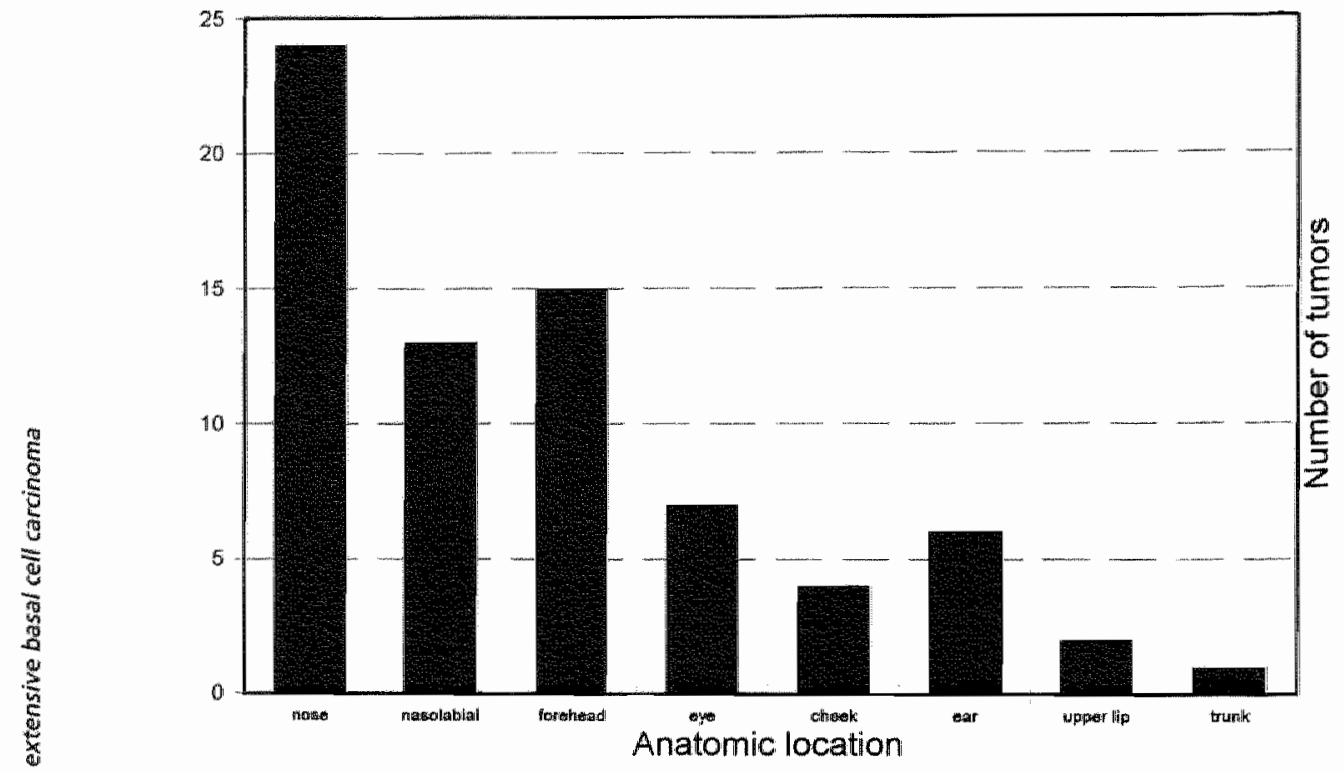

Figure 3. Anatomic distribution of 72 recurrent extensive $B C$ CS.

88

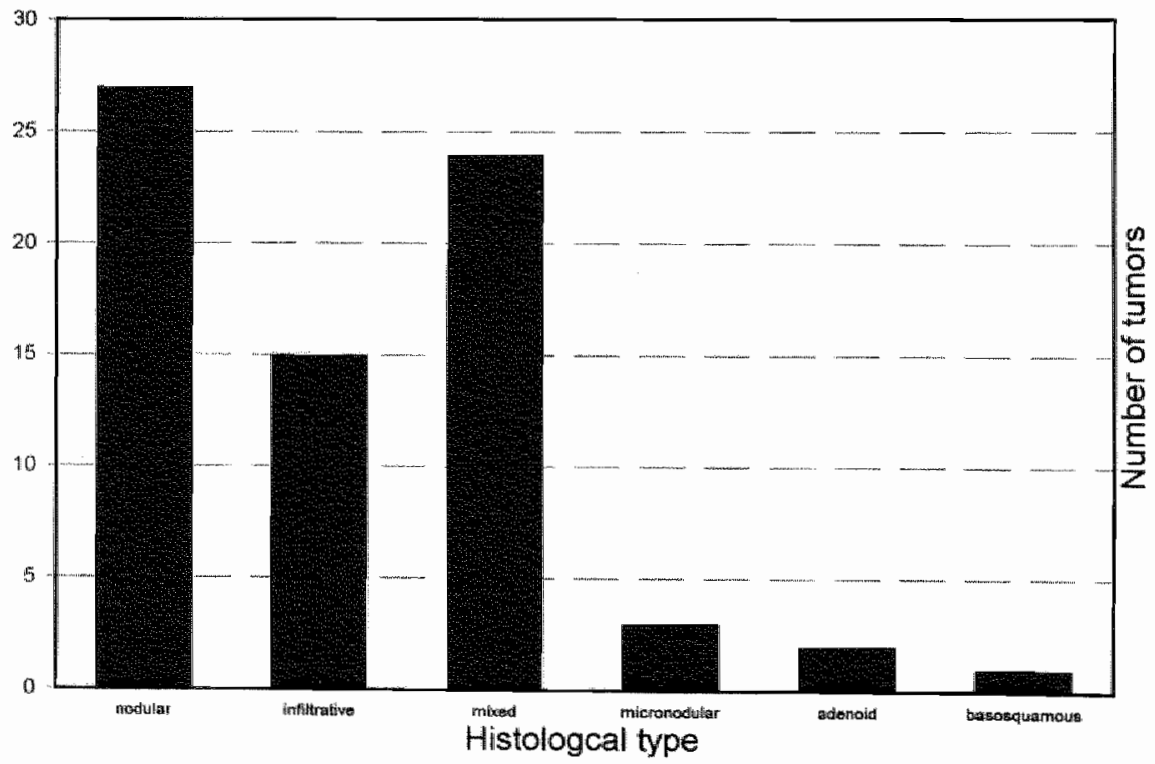

Figure 4. Histological subtypes of 72 recurrent extensive BCCs. 
Chapter 6 Recurrent extensive basal cell carcinoma

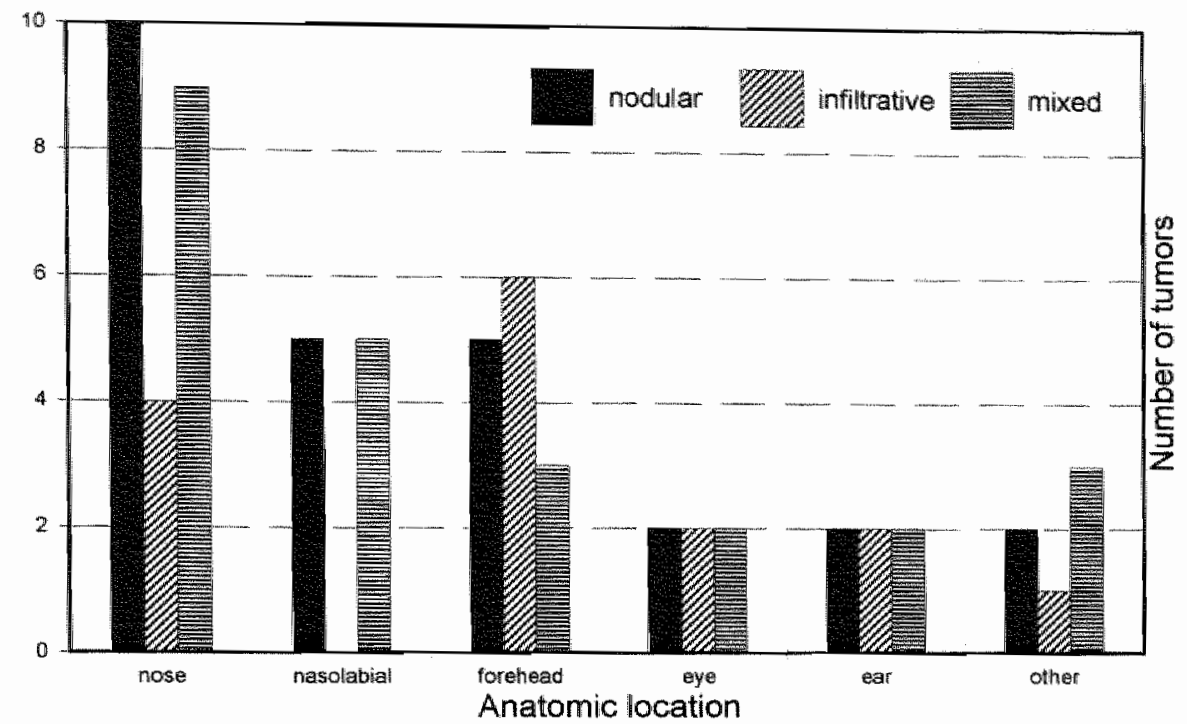

Figure 5. Distribution of the different histologic types of $\mathrm{BCC}$, correlated to the anatomic lacation $(n=65)$.

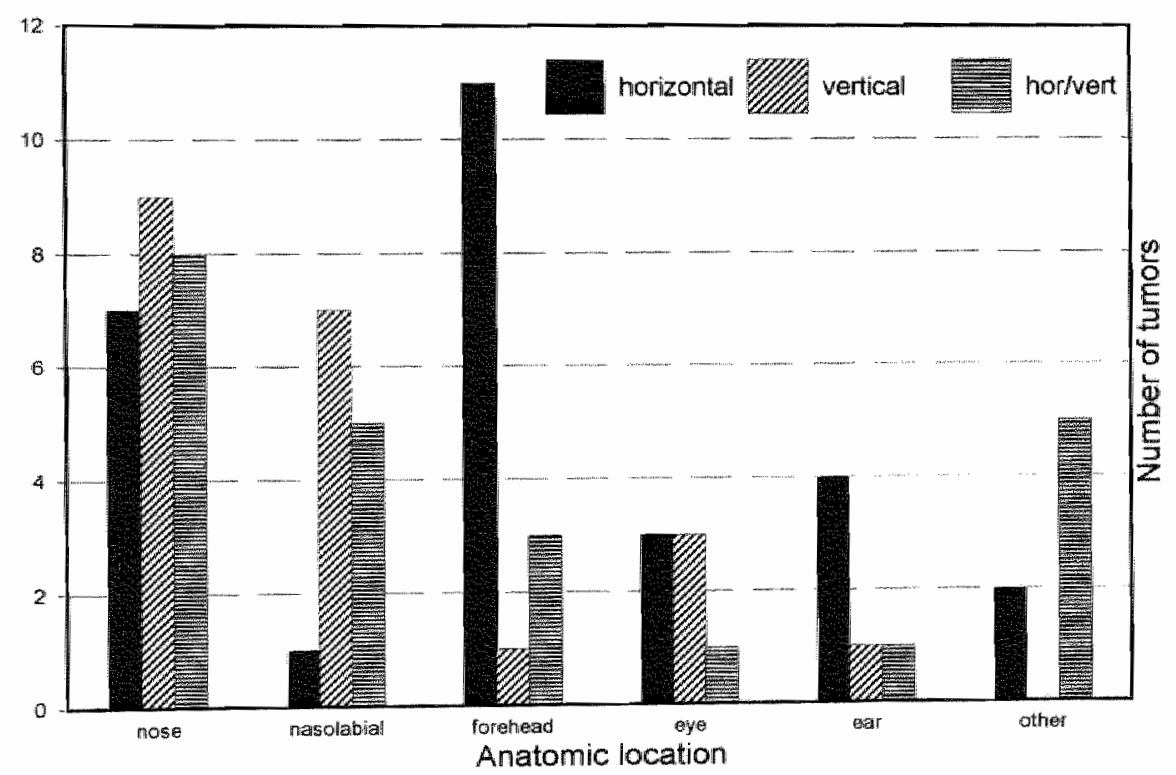

Figure 6. Subelinical outgrow patterns related to different anatomic locations ( $n=72)$ 


\section{Discussion}

Both clinical as well as histologic fearures have been described to be of prognostic significance in predicting aggressive behaviour of a $\mathrm{BCC}$.

The term 'aggressive' means the tendency for a BCC to recur after treatment and/or to invade deeply and widely, with resultant destruction or replacement of normal tissue. ${ }^{12}$

Besides recurrence of tumor, tumor size, tumor locarion and histological features also are correlared to agressive tumor behaviour.

In this study we selected 72 cases of recurrent BCCs with exrensive subclinical tumorgrowth, as demonstrated by at least three surgical Mohs stages before complete tumor removal was achieved.

First we will discuss the tumor size. Breuninger et al demonstrated that large tumors ( $>2 \mathrm{~cm}$ ) display significantly wider subclinical growth and higher recurrence rates compared with smaller $\mathrm{BCCs}(<1 \mathrm{~cm}) .{ }^{11}$ The mean preoperative tumor size in our study was $2.1 \mathrm{~cm}$ leading to a mean final surgical defect of $3.8 \mathrm{~cm}$. Therefore the mean surgical margin needed for complete excision of these 72 recurrent BCCs proved to be $8.5 \mathrm{~mm}$. Current surgical recommendations for primary BCCs call for margins of 2 to $5 \mathrm{~mm}$ in excision of nodular BCC and roughly 7 $\mathrm{mm}$ in infiltrative BCC, whereas for recurrent tumors an extra 2 to $3 \mathrm{~mm}$ should be added. ${ }^{13,14}$

In this study we especially focused on tumor location and histological features as risk factors for aggressive tumor behaviour.

Occasional series in the literature have reported a statistically significant association between location and recurrence. ${ }^{6,8,15}$ Particular problem areas include the central ' $\mathrm{H}$ zone' of the face and certain scalp lesions. The explanation for higher recurrence rates in these areas is probably multifactorial, including 1) tendency of tumor to spread along embryonic fusion planes, facial planes, periosteum and perichondrium, resulting in subdinical extension of the tumor, and 2) inadequate excisions in cosmetically important areas. ${ }^{16}$ Indeed, ninery-nine percent of our recurrent tumors were located in the face, of which the nasal-perinasal area was the most common site ( $51 \%$ ), followed by the forehead/temple region $(21 \%)$.

With regard to the histological features, at least 26 histopathological subtypes have been defined. ${ }^{17}$ Ir was Thackray who first correlated the histologic classification of BCCs with prognosis. ${ }^{18}$ Infiltrative and micronodular growth patrerns have been associated more with recurrence compared with the nodular types of BCC. ${ }^{19-22}$ These differences in recurrence rates are believed to be due to better well-defined clinical borders of the nodular types, resulting in a higher likelihood of total excision. Solid and superficial BCCs do nor differ in subclinical extension, whereas the more infiltrative types of BCC are characterized by larger, undetectable subclinical extensions that make them more difficult to excise completely. 
However, of our 72 recurrent BCCs selected for their subdinical expansion, 27 cases $(38 \%)$ demonstrated a purely nodular tumor growth. whereas only 15 cases (21\%) were of the infiltrative type. These results indicate that nodular BCCs also can behave in an aggressive fashion with extensive subdinical growth. Besides at purely nodular or infiltrating growth pattern, in 24 cases (33\%) a combination of borh was observed. This type was mainly characterized by a central mass of large, rounded islands and poorly circumscribed margins wirh spiky nests lacking palisading. These rumors are classified as nodular-infiltrating BCCs. ${ }^{12}$ We believe it is important to note these peripheral infiltrative elements because they appear to correlate with an increased tendency toward recurrence and biologically aggressive behaviour. Unfortunately, a diagnostic biopsy specimen initially taken of this type of tumor will show particularly a nodular growth pattern. Only the subsequent excision of the same $\mathrm{BCC}$ will demonstrate the peripheral infiltrating features, resulting in an increased risk of positive margins and a higher tecurrence rate. When we combine the results of the anatomic locations with the histological results, the nasolabial area $(n=10)$ shows the most interesting outcome. Seventyseven percent was of the nodular or nodular-infiltrative type, whereas the infiltrative type was not represented. $92 \%$ of the rumors was characterized by a vertical or a vertical/horizontal tumor expansion, whereas only $8 \%$ of the cases displayed a mainly horizontal growth pattern. The nose was almost equally represented by all different histological sub-types, with both horizontal and vertical tumor growth. Finally, the forehead displayed a predominance for horizontal subdinical extension of tumor.

\section{References}

1. Coebergh JWW, Neuman HAM, Vrints LW, van der Heijden L, Meijer WJ, Verhagen-Teurlings Mrh. Trends in the incidence of non-melanoma skin cancer in the netherlands 1975-1988: a registry-based study. Br J Dermarol 1991:125:353-9.

2. Preston DS, Srem RS. Nonmelanoma cancers of the skin. New Engl ] Med $1992 ; 327: 1649-62$.

3. Kirkham N. Tumors and cysts of the epidermis. In: Lever's Histoparhology of the Skin, 8th ed. Philadelphia: Lippincott-Raven Publishers, 1997:685-745.

4. Mehregan AH. Aggressive basal cell epithelioma on sun-light-protected skin: report of eighr cases, one with pulmonary and bone metastases. Am J Dermatopachol $1983 ; 5: 221-9$.

5. Sloane $\mathrm{JP}$. The walue of typing basal cell carcinomas in predicting recurrence after surgilcal excision. Br J Dermatol 1977;96:127-32.

6. Leffell DJ, Headington JT, Wong DS, Swanson NA. Aggressiva-growth basal cell carcinoma in young adults. Arch Dermatol 1991:127:1663-7. 
7. Mora RG, Robins P. Basal-cell carcinomas in the center of the face: special diagnostic, prognostic, and therapeutic considerations. J Dermatol Surg Oncol 1978;4:315-21.

8. Dubin N, Kopf AW. Multivariate risk score for recurrence of cutaneous basal cell carcinomas. Arch Dermatol 1983;119:373-7.

9. Mohs FE. Chemosurgery. Microscopically controlled surgery for skin cancer, ed. 2. Springfield, IL, 1978, Charles C Thomas.

10. Weedon D. Skin parhology. New York. 1997, Churchill Livingstone.

11. Breuninger $\mathbb{H}$, Dietz $K$. Prediction of subclinical cumor infiltration in basal cell carcinoma. J Dermarol Surg Oncol 1991;17:574-8.

12. Lang $\mathrm{PG}$, Maize JC. Histologic evolution of recurrent basal cell carcinoma and treatment implications. I Am Acad Dermatol 1986;14:186-96.

13. Salasche SI, Amonette RA. Morpheaform basal cell epitheliomas: a study of subclinical extension in a series of 51 cases. J Dermatol Surg Oncol 1981;7:21-4.

14. Zirelli JA, Wolf DI. Surgical margins for basal cell carcinoma. Arch Dermarol $1987 ; 123: 340-4$.

15. Levine HL, Bailin PL. Basal cell carcinoma of the head and neck: Identification of the high risk patient. Laryngoscope 1980;90:955-61.

16. Swanson NA, Grekin RC, Baker SR. Mohs Surgery: techniques, indications, and applications in head and neck surgery. Head Neck Surg 1983;6:683-92.

17. Wade TR, Ackerman AB. The many faces of Basal cell carcinoma. J Dermatol Surg Oncol 1978;4:23 8 .

18. Thackray AC. Hiscological dassification of rodent ulcers and its bearing on their prognosis. Br J Cancer 1951:5:213-6.

19. Malony ME. Histology of basal cell carcinona. Clinics in Dermatol 1995; 13:545-9.

20. Dixon AY, Lee SH, McGregor DH. Factors predictive of recurrence of basal cell carcinoma. Am J Dermatopathol 1989;11:222-32.

21. Hendrix,Jr JD, Parlette HL. Duplicitous growth of infiltrative basal cell carcinoma. Dermatol Surg 1996;22:535-9.

22. Hendrix,J JD, Parlette HL. Micronodular basal cell carcinoma. A deceptive histologic subtype wich frequent clinically undetected tumor extension. Arch Dermatol $1996: 132: 295-8$. 
Chapter 7

\section{Surgical margins for excision of primary and recurrent basal cell carcinoma}

M.E.J.M. Verhargh, F.W.G. Gruintjens, G.A.M. Krekels,

A.H.M. Vermeulen, H.A.M. Neumann

Submitted for publication 


\section{Summary}

The literature is quite variabie concerning recommendations as to the optimal surgical margins in the treatment of basal cell carcinoma (BCC).

Guidelines for surgilcal margins of a selected group of primary and recurrent BCCS were formulated on the basis of a retrospective study of 309 tumors treated by Mohs" micrographic surgery. To obtain the surgical margin, the maximal defiect-diameter was substracted by maximal tumor-diameter and divided by two.

In our group of primary BCCs selected for high-risk areas, large tumor size and/or aggressive histologic subtype, a minimum margin of $6 \mathrm{~mm}$ was required for complete removal of the tumor in more than $85 \%$ of the cases. The group of recurrent BCCs required margins of at least $10 \mathrm{~mm}$ to achieve a comparable tumor clearance.

Minimal margins of excision of $6 \mathrm{~mm}$ for primary and $10 \mathrm{~mm}$ for recurrent BCCs are proposed for our selected group of high risk tumors. Previous treatment (recurrent tumors) and large tumor diameter (larger than $2 \mathrm{~cm}$ ) proved to be the two most important risk factors correlated with extensive subclinical tumor expansion. For these high risk tumors Mohs' micrographic surgery is the procedure of choice. 
Chapter 7 Surgital margins for excision

\section{Introduction}

$\mathrm{BCC}$ is the most common malignancy in humans, predominantly found on sunexposed areas of the skin. ${ }^{1}$ The incidence of $\mathrm{BCC}$ is rapidly increasing worldwide. 2,3 In the Netherlands ( 15 million inhabitants), approximately $18.000 \mathrm{BCCs}$ were diagnosed in 1994, with an estimated increase of $2.700 \mathrm{BCC}$ yearly.

$\mathrm{BCCs}$ are typically slow-growing tumors, often taking months to years to reach significant clinical proportions. Besides clinical proportions, BCCs also are characterized by varying subdinical tumor extensions. This is the reason that especially in BCCs the recommended margins of excision are quite variable, ranging from 2 $\mathrm{mm}$ to more than $1 \mathrm{~cm}^{4-15}$

Most BCCs are relatively 'non-aggressive' tumors that are cured by various methods of treatment like conventional surgery, cryosurgery, curettage and electrodesiccation, and radiotherapy. Rowe et al described a recurrence rate for primary $\mathrm{BCC}$ of $8.7 \%$ for all of the treatments above. ${ }^{16}$

A minority of tumors, however, display a more aggressive biological behaviour with a more extensive local tissue destruction and multiple recurrences, e.g. "high risk" BCCs. Factors that are correlated with aggressive tumor behaviour include tumor location, tumor size and histologic subtype. ${ }^{17}$

Mohs' micrographic surgery (MMS), a method that provides complete microscopic control of the surgical margin with a long term recurrence rate for primary $\mathrm{BCC}$ of $1.0 \%$, seems particularly useful for managing these aggressive-type BCCs. ${ }^{16,18}$

MMS also is the ideal procedure for methodically mapping BCC growth patterns and so determinating the tumors' excision-margins. These characteristics will be used in this study of $309 \mathrm{BCCs}$, supported by a literature-overview. Proposals for surgical margins for primary as well as recurrent BCCs will be offered, in order to achieve tumor clearance rates of at least $85 \%$.

\section{Material and Methods}

A retrospective study was performed on a total of 898 histologically confirmed BCCs treated with conventional surgery $(n=589)$ or MMS $(n=309)$ at the University Hospital Maastrichr in the period berween 1992 and 1996.

MMS is a standard treatment for BCCs in the United States of America. In Europe, where MMS is less widely available and accepted, only a selected group of $\mathrm{BCC}$ is treated by this technique. Selection criteria applied in Maastricht are summarized in Table I.

The remaining group of $\mathrm{BCCs}(\mathrm{n}=589)$, not selected for MMS, was treated by conventional surgery with a standard excision margin of $3 \mathrm{~mm}$. 
Table I Selection critera tor Mons micrographic surgery applied in the Uniwersity hospinal Maastricht.

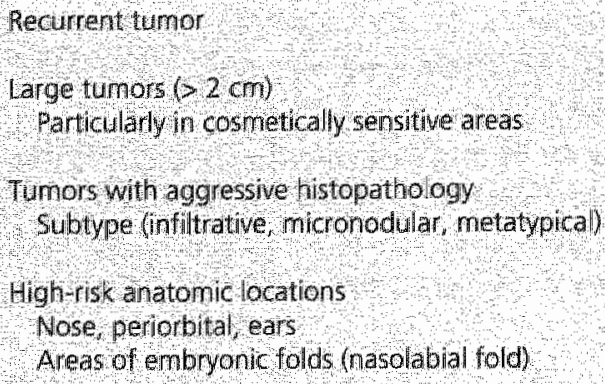

The following parameters are available: age, sex, location, pre-operative tumorsize and post-operative defect size, vertical and horizontal infiltration type, histologic-subtype, previous therapies, reconstruction strategies, follow-up time and MMS-recurrence.

Anatomic tumor-locations were divided in forehead/temple, periocutar and canthi, nose, paranasal/alar base/nasal-labial groove, cheek, eat and pre/post auricular and 'other' locations.

Pre-operative tumor sizes and post-operative defect sizes were measured during the MMS session. Maximal tumor-diameter and maximal defect-diameter were obtained by measuring the longest axe of tumor and defect. To obtain the tumormargin, the maximal defect-diameter was substracted by maximal tumordiameter and divided by two.

Horizontal and vertical infiltration mode was adapted from the infiltration models of Breuninger et al. ${ }^{19}$

Histologic subtypes were divided in nodular $\mathrm{BCC}$, infiltrating $\mathrm{BCC}$, nodular/infiltrating $\mathrm{BCC}$, micronodular $\mathrm{BCC}$, superficial $\mathrm{BCC}$, basosquamous $\mathrm{BCC}$, adenoid BCC and category 'other' according to Weedon. ${ }^{20}$

Previous therapies consisted of surgery, cryotherapy, radiotherapy, MMS, curretage and electrodessication or combinations of these.

\section{Results}

A series of 309 selected BCCs treated by MMS was reevaluated. The number of surgical Mohs stages was 1-8 (mean 2.4) and frozen slides 2-55 (mean 9.3). Of all patients $181(59 \%)$ were male between the ages of 31 and 88 years (mean 64.2) 
Chapter 7 Surgical margins for exclston

Table I. Histologic subtypes categonized by anatomic location.

\begin{tabular}{|c|c|c|c|c|}
\hline & Forehead & Eye & Nose & Paranasal \\
\hline Noduluar & $34 \%(h-20)$ & $46 \%(n-20)$ & $28 \%(n=29)$ & $58 \%(n=19)$ \\
\hline rfiltrative & $33 \%(n=20)$ & $20 \%(n=07)$ & $4696(n-47)$ & $1106(n=04)$ \\
\hline Modular/nfiler & $09 \%(n=05)$ & $13 \%(n=06)$ & $15 \%(n-16)$ & $18 \%(n=06)$ \\
\hline Other & $24 \%(n-14)$ & $276(n=10)$ & $11 \%(n-11)$ & $13 \%(n=04)$ \\
\hline Total & $100 \%(n=59)$ & $100 \%(n-43)$ & $100 \%(n-103)$ & $100 \%(n-33)$ \\
\hline
\end{tabular}

and $128(41 \%)$ were female between 31 and 94 years old (mean 67.5). The overall mean age was 65.5 years.

Of the 309 BCCs 138 (45\%) were primary tumors. In the recurrent group $(\mathrm{n}=171) ; 127(75 \%)$ tumors had been previously treated once, 21 (12\%) twice, 9 $(5 \%)$ three times and $14(8 \%)$ tumors had been previously treated at least four times. These previous modalities of treatment included: surgery $(\mathrm{n}=90)$, cryotherapy $(n=19)$, $X$-ray therapy $(n=10)$, curettage-electrodesiccation $(n=3)$, surgery and $X$ ray therapy $(n=13)$, surgery and cryotherapy $(n=11)$ and MMS $(n=9)$.

Almost all $\mathrm{BCCs}$ were located in the face. The most frequent locations were the nose ( $n=103 ; 33 \%)$, the forehead/temple ( $n=59 ; 19 \%)$, the periocular and canthi region $(\mathrm{n}=43 ; 14 \%)$, the alar base/nasal-labial groove $(\mathrm{n}=33 ; 11 \%)$, the cheek $(n=25 ; 8 \%)$, the ear and pre/post auricular region $(n=21 ; 7 \%)$.

The following histologic patterns and their respective numbers and frequencies were observed: nodular type $(n=111 ; 36 \%)$, infiltrative type $(n=101 ; 33 \%)$, nodular/infiltrating type $(n=49 ; 16 \%)$, micronodular type $(n=11 ; 4 \%)$, superficial type $(n=9 ; 3 \%)$, baso-squamous type $(n=8 ; 2 \%)$, adenoid type $(n=6 ; 2 \%)$ and category 'other' $(n=14 ; 4 \%)$. The histologic subtypes are categorized by their anatomic location in Table II.

The pre-operative tumor size of both primary and recurrent BCCs was $2-100 \mathrm{~mm}$ (mean $15.9 \mathrm{~mm}$ ). The final size of the Mohs surgical defect ranged in diamerer from $5-150 \mathrm{~mm}$ (mean $27.5 \mathrm{~mm}$ ). The mean tumor size and surgical defect for primary and recurrent $\mathrm{BCC}$ respectively were $14.4 / 24.1 \mathrm{~mm}$ and $17.2 / 30.3$ $\mathrm{mm}$. The mean surgical margin for our selected group of BCCs treated by MMS was $5.8 \mathrm{~mm}$. The mean surgical margin for primary and recurrent BCCs was 4.9 $\mathrm{mm}$ and $6.6 \mathrm{~mm}$ respectively.

The relation of tumor size and surgical margins was determined. Tumors were grouped according to maximum diameter: 0 to $9 \mathrm{~mm}, 10$ to $19 \mathrm{~mm}$, or $20 \mathrm{~mm}$ and larger. The mean surgical margins were 5.1, 5.2 and $7.4 \mathrm{~mm}$ respectively. The differences in surgical margins between primary and recurrent tumors according to tumor size also were determined. Primary BCCs $(n=138) ; 3.8 \mathrm{~mm}$ (tumor size 


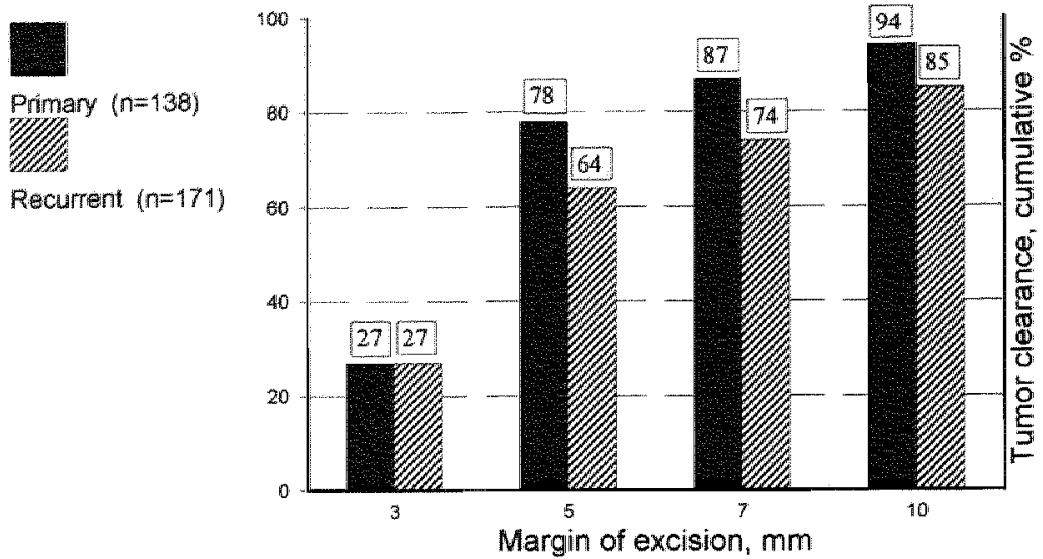

Figure 1. Rate of tumor clearance for various margins of excision in 309 BCCs studied.

$0-9 \mathrm{~mm}$ ), $5.2 \mathrm{~mm}$ (tumor size $10-19 \mathrm{~mm}$ ) and $5.9 \mathrm{~mm}$ (tumor size $>20 \mathrm{~mm}$ ). Recurrent BCCs $(n=171) ; 6.3,5.2$ and $8.1 \mathrm{~mm}$ respectively.

The effect of the three mosit common histologic subtypes on surgical margins also was studied. The mean surgical margin for nodular-type BCC (n-111) was $5.5 \mathrm{~mm}$, for the infiltrative type $(\mathrm{n}=101) 4.9 \mathrm{~mm}$ and for the nodular/infiltrative type $7.1 \mathrm{~mm}$. The minimal lateral margins for clearance were determined in the 309 tumors studied. A 3 mm margin only cleared $27 \%$ of our BCCs, whereas our mean margin of $5.8 \mathrm{~mm}$ cleared $73 \%$ af the cases. The standard of $85 \%$ tumor clearance was achieved with $7.5 \mathrm{~mm}$ margins. The differences between primary and recurrent tumors also was studied (Fig. 1). A 6 mm margin cleared $85 \%$ of the BCCs in the group of primary tumors, whereas a margin of $10 \mathrm{~mm}$ was needed in the recurrent group. The rate of cumor clearance as function of tumor size and histologic tumor type of both primary and recurretnt BCCs are illustrated in Figures $2-5$.

Next, the subclinical growth pattern is presented. Among all BCC subtypes, $40 \%$ $(n=125)$ of the cases diplayed a predominantly horizontal subclinical growth, $23 \%$ $(n=70)$ vertical and $14 \%(n=43)$ were characterized by both horizontal and verticall tumor extension. In $23 \%(\mathrm{n}=71)$ of cases the subclinical growth pattern remained unknown because of a minimum of surgical Mohs stages.

The following reconstructions were performed: primary closure $(\mathrm{n}=58 ; 19 \%)$, advancement fap $(n=49 ; 16 \%)$, transposition flap $(n=41 ; 13 \%)$, rotation flap $(n=33 ; 11 \%)$, subcutaneous pedicle flap $(n=17 ; 6 \%)$, full-thickness graft $(n=37$; $12 \%)$, split-skin graft $(n=42 ; 14 \%)$, secundary healing $(n=4 ; 1 \%)$ and category other $(n=25 ; 8 \%)$.

Until now eleven recurrences $(3,5 \%)$ accurred, within a mean follow-up time of 28.7 months. 


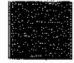

$<10 \mathrm{~mm}(\mathrm{n}=50)$

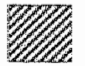

$10-20 \mathrm{~mm}(\mathrm{n}=62)$

$=$

$20 \mathrm{~mm}(n=26)$

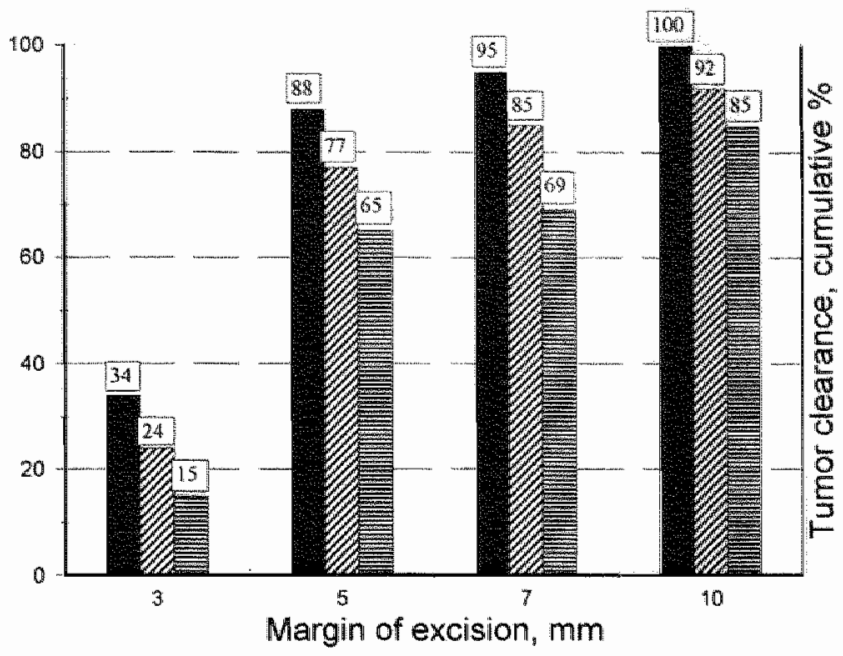

Figure 2. Rate of tumor clearance as function of tumor size in 138 primary $B C C 5$.

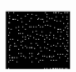

$<10 \mathrm{~mm}(n=53)$

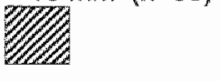

$10-20 \mathrm{~mm}(\mathrm{n}=74)$

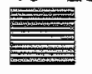

$>20 \mathrm{~mm}(n=44)$

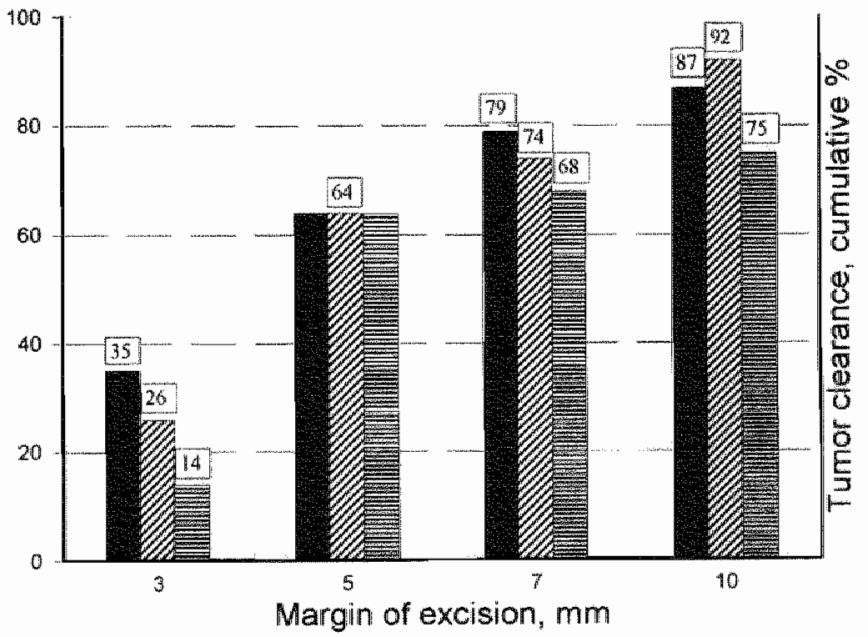

Figure 3. Rate of tumor clearance as function of tumor size in 171 recurrent BCCS 


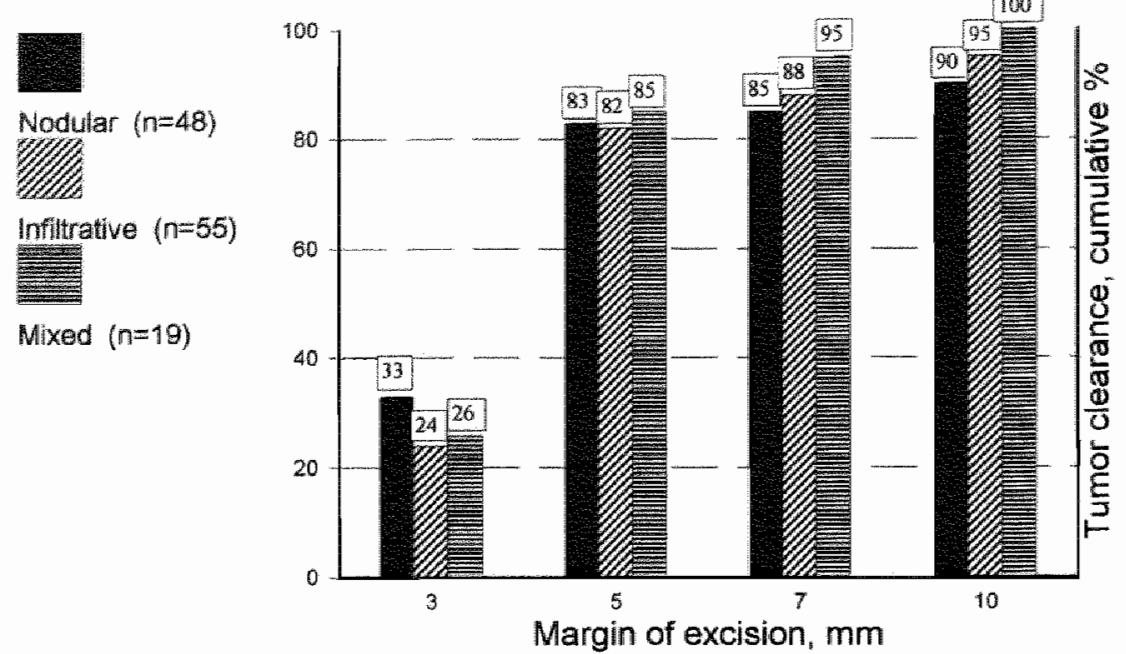

Figure 4. Rate of tumor clearance as function of tumor type in 122 primary BCCS.

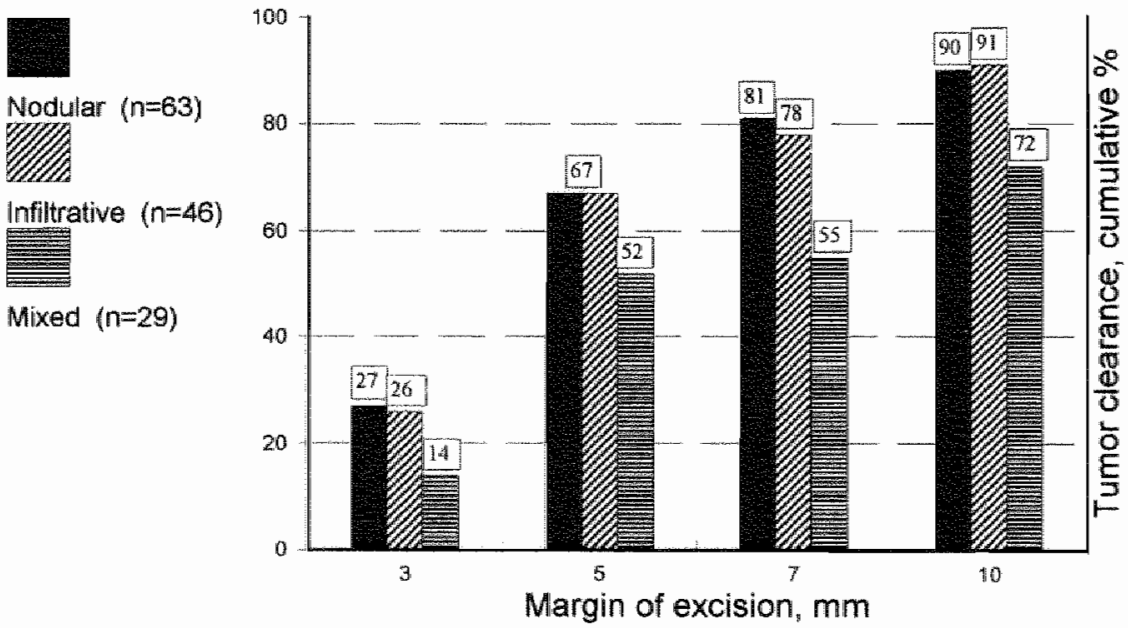

Figure 5. Rate of tumor clearance as function of tumor type in 138 recurrent $B C C_{5}$. 
Chapter 7 Surgical matrgins for excision

\section{Discussion}

The goals in the treatment of BCC are complete removal of the tumor and conserving normal tissue as much as possible. Since the probability of presence of tumor nests or strands beyond the clinical margins has been well documented, ${ }^{4-15}$ normal-appearing skin must also be removed or destroyed to achieve acceptable cure rates.

Until now only a few studies have been published in which the authors presented some recommendations regarding excision-margins for $\mathrm{BCC}^{4-15}$ These recommendations varied from $2 \mathrm{~mm}$ to $10 \mathrm{~mm}$ (Table III). Unfortunately, in most of these studies important factors like recurrence, histology and location were not included and the correlation between the histologic and clinical extent of the tumor was not studied by $100 \%$ margin examination. In fact, MMS, with its inherent microscopic control of all tissue margins, seems the most appropiate method to determine subclinical extensions of BCCs.

The two most informative and well designed studies will be discussed. First, Wolf et al studied 117 cases of previously untreated, well-demarcated BCCs. ${ }^{13}$ Of the 117 cases, 11. lesions (9\%) were greater than $2 \mathrm{~cm}$ and only a few cases displayed infiltrative features. Remarks concerning tumor location were not included in this study. Prior to excision, the normal-appearing skin surrounding the tumor was marked in $2 \mathrm{~mm}$ increments. This method was used because of the tendency of wound expansion following full-thickness tumor excision. All tumors were treated by MMS. For tumors with a diameter less than $2 \mathrm{~cm}$, a margin of $3 \mathrm{~mm}$ would have eliminated the tumor completely in approximately $85 \%$ of the cases.

Breuninger et al, studied a total of $2016 \mathrm{BCCs} .{ }^{14}$ Of the 1757 primary $\mathrm{BCCs}, 177$ (10\%) were greater than $2 \mathrm{~cm}, 916(52 \%)$ were exclusively nodular and 230 $(13 \%)$ exclusively infiltrative. Histologic confirmation of the specimen margins took place with modified micrographic surgery and three-dimensional study in paraffin sections. ${ }^{21}$ For primary and recurrent tumors, margins of $4 \mathrm{~mm}$ and 6 $\mathrm{mm}$ respectively were required to achieve tumor clearance in $85 \%$ of the cases. Their results showed that the subclinical extension of BCCs is determined largely by the size of the tumor and the histologic type. Anatomic location and tumor age only indirectly affected subclinical extension.

At the University Hospital Maastricht, in the period 1992-1996, 898 BCCs were treated by surgical means. 309 of these $898 \mathrm{BCC}$ were selected for MMS (criteria given in Table 1). The remaining 589 tumors, mostly small, previously untreated, well-defined, nodular type BCCs, were treated by surgical excision with a standard surgical margin of $3 \mathrm{~mm}$. Post-operative histopathologic examination took place by vertical step sectioning (breadloaf method). In 104 of the 589 cases positive specimen margins were detected, resulting in a tumor clearance of $82 \%$. One should keep in mind that this method of routinely vertical sectioning through rep- 
Table lli, summan of adviced surgical margins for BCC

\begin{tabular}{|c|c|c|c|c|}
\hline Author & Year & Type & Advee & Risk factor \\
\hline Derne & 1959 & $169 \mathrm{BCC}$ & $510 \mathrm{~mm}$ & lacation (nose) infiltrat ve type \\
\hline Macomber & 1959 & $853 \mathrm{BCC}$ & $5 \mathrm{~mm}$ & 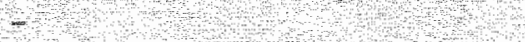 \\
\hline Rintala & 1971 & $204 \mathrm{BCC}$ & $5 \mathrm{~mm}$ & size of unaor \\
\hline Gritinh & 1973 & $834 \mathrm{BCC}$ & $310 \mathrm{~mm}$ & SIzE OL UMOH \\
\hline Epstein & 1973 & $131 \mathrm{BCC}$ & $2 \mathrm{~mm}$ & size of tumor, infiltrative type \\
\hline Bart & 1978 & $468 \mathrm{BCC}$ & $35 \mathrm{~mm}$ & location (penocular, scalp, nose, paranasall \\
\hline Koplin & 1980 & review: & $2-4 \mathrm{~mm}$ & size of tumor, location, recurrence \\
\hline Albight & 1982 & review: & $210 \mathrm{~mm}$ & size of tumor \\
\hline Breuninger & 1984 & $742 \mathrm{BCC}$ & $2-5 \mathrm{~mm}$ & size of lumor \\
\hline Wolf & 1987 & $117 \mathrm{BCC}$ & $3-4 \mathrm{~mm}$ & size of tumon \\
\hline Breuninger & 1991 & $20168 C C$ & $3-7 \mathrm{~mm}$ & size of tumor, infiltrative ype, recurrence \\
\hline Hendrx hr & 1996 & $278 \mathrm{BCC}$ & $4-10 \mathrm{~mm}$ & Infiltratue ype, recurrence \\
\hline Verhaegh: & 1998 & $309 \mathrm{BCC}$ & $610 \mathrm{~mm}$ & size of tumor; recurrence \\
\hline
\end{tabular}

resentative areas of the specimen only permits the examination of less than $0.1 \%$ of the actual tissue margins. ${ }^{22}$

Of the 309 BCCs treated by MMS, 171 were recurrent ones. Primary tumors were selected for MMS because of their size (larger than $2 \mathrm{~cm}$ ), site (anatomic regions known for their increased risk of recurrence, or critical locations, such as the eyelid or lip, benefitting from the tissue-sparing aspects of the Mohs technique), and histologic subtype (infiltrative, micronodular, and mixed).

If this selected group of primary tumors would have been treated by the standard surgical margin of $3 \mathrm{~mm}$, only $27 \%$ of the cases would have been excised radically. In this study we demonstrated that subclinical extensions of BCCs are mainly derermined by previous treatment and the size of the tumor, especially tumors larger than $2 \mathrm{~cm}$ (Fig. 1-3).

Besides recurrent tumors and tumor size, the histological subtype also is described to be of significant importance concerning subclinical tumor extensions. ${ }^{23}$

Recently, Hendrix et al showed, that the width of tissue required to remove subclinical extension of tumor was significantly greater with infiltrative $\mathrm{BCC}$ when compared with nodular BCC for primary tumors $(5.6 \mathrm{~mm}$ vs $4.3 \mathrm{~mm}$ ) and recurrent tumors (10.4 mm vs $5.7 \mathrm{~mm}) .{ }^{15}$ Our results only partly confirm their findings (Fig. 4,5). Especially the recurrent mixed type tumors (nodular and infiltrative characteristics in the same tumor) displayed extensive subclinical tumor growth.

Anatomic tumor location is not discussed here because of the fact that almost all our tumors were located in the so called central " $\mathrm{H}$-zone" of the face, which is described to be correlated with a higher tumor aggressiveness. ${ }^{24,25}$ In our experience, 
Chapter 7 surgical margins for excision

Table IV Safety margins (mm) of primay and recurent BCCs according Verhaegh et al and Breuninger et al that ensure tumar free excisional margins in approximately $85 \%$ of the cases.

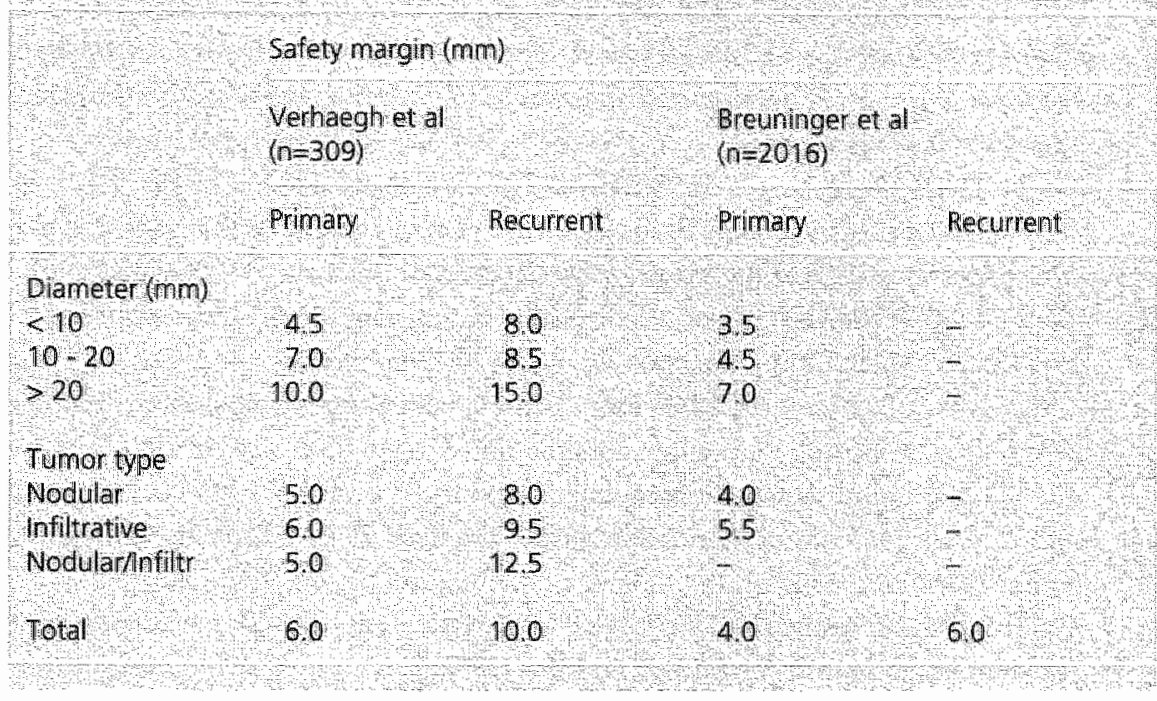

the most aggressive and destructive BCCs were localized in the nasal-labial groove and medial canthus areas. Worth mentioning, most of them were of the nodular type, and were characterized by extensive vertical tumor expansion.

In conclusion, the recommended safety margins of high risk BCCs (Table 1 ) are summarized in Table IV. We have found by studying these $309 \mathrm{BCC}$ that a minimum margin of $6 \mathrm{~mm}$ for primary and $10 \mathrm{~mm}$ for recurrent BCCs was necessary to eradicate a tumor in $85 \%$ of the cases.

However, the methodology we used calculating the extent of the subclinical tumor invasion is correlated to some degree of variability. The subdinical extension was determined by dividing by half the difference between the maximal postoperative defect size and the maximal preoperative lesion size. This method does not compensate for wound expansion caused by gaping of the skin and/or orienting of the defect along the relaxed skin tension lines. Furthermore, our formula for the determination of the subclinical extension assumes that the extension of the tumor is symmetrical in all areas, although it is well known that subclinical extension in $\mathrm{BCC}$ is mostly asymmetric. In summary, presurgical marks with gentian violet at $2 \mathrm{~mm}$ increments along radial lines in all directions from the tumor borders, as described by Wolf et al ${ }^{13}$ deserves the preference above our methodology.

To conclude, in our opinion MMS is the preferred rechnique for treatment of this group of high risk $\mathrm{BCCs}$, because of the routine methodic accuracy in evaluating $100 \%$ of the surgical margins of the specimen, the subsequent high rare of oncologic cure, and the tissue-sparing quality of the procedure. 


\section{References}

1. Miller S]. Biology of basal cell carcinoma (part I). J Am Acad Dermatol 1991;24:1-13.

2. Gallagher RP, Ma B, McLean DI, et al. Trends in basal cell carcinoma, squamous cell carcinoma, and melanoma of the skin from 1973 chrough 1987. J Am Acad Dermatol 1990;23:413-21.

3. Coebergh JWW, Neumann HAM, Vrints LW, van der Heijden L, Meijer WJ, Verhagen-Teulings $M t h$. Trends in the incidence of non-melanoma skin cancer in the SE Netherlands 1975-1988: a registry-based study. BrJ Dermatal 1991;125:353-9.

4. Beirne GA, Beime CG. Observations on the critical margin for the complete excision of carcinoma of the skin. Arch Dermatol 1959;80:344-5.

5. Macomber WB, Wank MKH, Sullivan JG. Cutaneous epithelioma. Plast Reconstr Sufg 1959;24:545-62.

6. Rintala A. Surgical therapy of basal cell carcinoma. Correlation of the macroscopic and microscopic control of excision with recurrence. Scan J Plast Reconstr Surg $1971 ; 5: 87-90$.

7. Griffith $\mathrm{BH}$, McKinney P. An appraisal of the treatment of basal cell carcinoma of the skin. Plast Reconstr Surg 1973;51:565-71.

8. Epstein $\mathbb{E}$. How accurate is the visual assessment of basal cell carcinoma margins? $\mathrm{Br}$ J Dermatol 1973;89:37-43.

9. Bart RS, Schrager D, Kopf AW, Bromberg J, Dubin N. Scalpel excision of basal cell carcinomas. Arch Dermatol 1978;114:739-42.

10. Koplin L, Zarem HA. Recurrent basal cell carcinoma. A review concerning the incidence, behavior and management of recurrent basal cell carcinoma, with emphasis on the incompletely excised lesion. Plast Reconstr Surg 1980;65:656-64.

11. Albright SD. Treatment of skin cancer using multiple modalities. J Am Acad Dermatol 1982;7:143-71.

12. Breuninger $\mathrm{H}$. Histologic control of excised tissue edges in the operative treatment of basal cell carcinomas. J Dermatol Surg Oncol 1984;10;724-8.

13. Wolf DI, Zitelli JA. Surgical margins for basal cell carcinoma. Arch Dermatol 1987;123:340-4.

14. Breuninger $\mathrm{H}$, Dietz K. Prediction of subclinical tumor infiltration in basal cell carcinoma. J Dermatol Surg Oncol 1991;17:574-8.

15. Hendrix Jr JD, Parlette HL. Duplicitous growth of infiltrative basal cell carcinoma. Dermatol Surg 1996;22:535-9.

16. Rowe DE, Carroll RJ, Day Jr CL. Long-term recurrence rates in previously untreated (primary) basal cell carcinoma: implications for patient follow-up. J Dermatol Surg Oncol 1989;15:315-28.

17. Randle HW. Basal cell carcinoma. Identification and treatment of the high-risk patient. Dermatol Surg 1996;22:255-61.

18. Mohs FE. Chemosurgery. Clin Plast Surg 1980;7:349-60. 
19. Breuninger $H$, Dietz $K$, Rassner $G$. Das sublinische Infiltrationswerlalten von Basaliomen. Akt Dermatol 1992;18:129-32.

20. Weedon D. Skin parhology. New York: Churchill Livingstone, 1997:647-51.

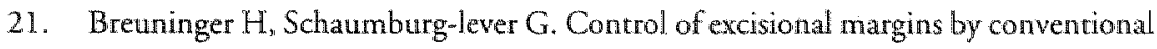
histopathological techniques in the treatment of skin tumours. An alternative to Mohs' technique. J Pathol 1988;154:167-71.

22. Abide JM, Nahai F, Bennett RG. The meaning of surgical margins. Plast Reconstr Surg 1984;73:492-6.

23. Orengo IF, Salasche SJ, Fewkes J, Khan J, Thornby J, Rubin E. Correlation of histologic subrypes of primary basal cell carcinoma and number of Molns stages required to achieve a cumor-free plane. J Am Acad Dermatol 1997:37:395-7.

24. Mora RG, Robins P. Basal-cell carcinomas in the center of the face: special diagnostic, prognostic, and therapeutic considerations. J Dermatol Surg, Oncol 1978; 4 : 315-21.

25. Roenigk RK, Ratz JL, Bailin PL, Wheeland RG. Trends in the presentation and trearment of basal cell carcinomas. I] Dermatol Surg Oncol 1986:12:860-5. 



\section{Chapter 8}

\section{General discussion and summary}

In this final chapter an attempt will be made to summarize and discuss the results presented in this thesis in a somewhat broader conrext than was aimed in the discussion of the individual chapters. Three main themes will be adressed. First, our findings in chapters 2 and 3 are discussed in rellation to the possible role of specific cell-mediated immunity as an important mechanism in limiting BCC tumor spread. Second, the role of programmed cell death regarding BCC tumor growth, scudied by $b c l-2$, will be discussed by reviewing chapters 4 and 5 . Finally, clinical and histological features of BCCs, and their consequences upon optimal therapeutical care are discussed in the context of chapters 6 and 7.

Basal cell carcinomas (BCCs) are frequently associated with a peritumoral mononuclear cell infiltrate. The infiltrate surrounding BCC tumor islands largely consists of $T$ cells with a predominance of the CD4+/T-helper (Th) over the $\mathrm{CD} 8+/ \mathrm{T}$-cytotoxic $(\mathrm{Tc})$ subset (Th/Te ratio of $1.9 \pm 0.8$ ), similar to that found in typical delayed hypersensitivity reactions. Natural killer cells $(\mathrm{NK})$ and $\mathrm{B}$ cells are seen in much lower numbers.

In the last decade, several investigators have attempted to elucidate the function of this cellular inflammatory infiltrate surrounding these skin cancers and its possible role in controlling tumor growth.

The relatively benign tumor-behaviour, areas of spontaneous regression and the therapeutic response to intralesional administration of cytokines, such as IL-2 and IFN- $\alpha$, are in favour of a specific anti-tumor immune response in BCC. On the other hand, the observations that the stromal inflammatory reaction surrounding $\mathrm{BCC}$ is usually mild, $\mathrm{T}$ cells do not infiltrate BCC tumor lobules and the frequency of BCC in immunosuppressed patients is only slightly increased compared with squamous cell carcinoma, argue against a specific anti-tumor response.

In chapter 2 , we investigated if $B C C$ tumor cells and endothelial cells of the peritumoral vasculature express adhesion molecules.

A tumor specific cellular immune response is considered to be associated with adhesion molecule expression on endothelial cells for recruitment of $\mathrm{T}$ cells in to the tissue, and on curnor cells for lymphocyte-target cell interaction. 
Recent interest has focussed upon three cytokine-inducible leukocyte adhesion molecules, designated intercellular adhesion molecule-1 (ICAM-1), vascular cell adhesion molecule-1 (VCAM-11), and E-selectin.

ICAM- $\mathbb{1}$, which is inducible by IFN- $\gamma$ and TNF- $\alpha$, is expressed by a wide variety of cells, including resting endothelial cells and binds virtually all circulating white cells. E-selectin and VCAM- 1 expression correllates with endorhelial cell acrivarion and is both inducible by TNF- $\alpha$ and IL-1.

The expression and distribution of the adhesion molecules ICAM-1, VCAM-1 and E-selectin by microvascular endothelial cells and tumor cells, togerher with their leukocyte receptors LFA-1, VLA-4 and CLA respectively, were studied in 33 BCCs of different histological subrypes.

Endothelial ICAM-1 expression was only slightly increased compared to normal skin, whereas expression of endorhelial VCAM-1 and E-selectin was low or absent in all BCCs examined. Peritumoral infiltrates contained mostly $L F A-1$ expressing lymphocytes, with minimal VLA-4 and CLA positivity.

In none of the cases studied adhesion molecule expression of BCC tumor cells was identified.

This observed failure to express adhesion molecules on tumor cells possibly enables malignant cells to escape immunosurveillance, by preventing binding of the Tlymphocyte to the target cell.

The inability of BCC tumor cells to express adhesion mollecules is not absolute. Taylor et al presented a study where they demonstrated induction of ICAM-1 expression on tumor cells after BCC tissue had been incubated in witro with IFN- $\gamma{ }^{1}$ The absence of adhesion molecules on BCC tumor cells as well on the overlying epidermal keratinocytes as demonstrated in this study, together with the moderate ICAM- 1 and minimal VCAM- 1 or E-selectin expression on the surrounding peritumoral endothelial cells could be explained by insufficient in wivo cytokine levels. Two causal hypotheses of insufficient in vivo cytokine levels will be discussed.

First, activated Tlymphocytes are an important source of cytokines, especially those $\mathrm{T}$ lymphocytes responding to tumor-antigen srimulation. Different stages of lymphocyte activation are characterized by the appearance of specific cell surface antigens, such as IL-2 receptor, transferrin receptor and HLA-DR expression. The presence of activated $\mathrm{T}$ cells surrounding $\mathrm{BCC}$ has been demonstrated; with up to $30 \%$ to $50 \%$ of cells expressing activation antigens on their surfaces. ${ }^{2}$ Whether this only distinguishes them from naive $T$ cells activated by general stimuli (for example epidermal ulceration, a characteristic feature of nodular type BCCs》, or supports the concept of tumor-derived antigens iniriating a cell-mediated host-specific response is as yet unclear.

Second, CD4+ T cells are recently subdivided into functional subsets (Th1 and Th2) based upon cytokine profiles. Th1 cells produce IL-2, IFN- $\gamma$ and TNE- $\alpha$, resulting in $T$ cell proliferation and macrophage activation, characteristic of cell- 
mediated immune responses. In contrast, Th2 cells produce $I L-4, \mathbb{L}-5$, and IL-10, cytokines that augment antibody responses. Recently, Yamamura et al demonstrated IL-4, IL-5, and IL-10 mRNAs in BCC lesions and concluded that a particular $T$ cell population producing type-2 cytokines accumulates in $B C C .{ }^{3}$ Obviously, if Th1 cells are indeed in the minority in BCCs, a low level of IFN- $\gamma$ may be the cause of absence of ICAM- 1 expression in BCC. Thus, BCC progression may be assisted by the activation of Th 2 cells involved in antibody formation, and suppression of a population of Th1 cells that normally contribute to tumor stasis or elimination.

In conclusion, besides identifying the presence of adhesion molecules on both wascular endothelial cells and BCC tumor cells, as demonstrated in this study, information about the composition of the infiltrate also is essential.

We would especially be interested in new techniques differentiating Th1 from Th2 cells, and also in new monoclonal antibodies differentiating immune effector cells specifically activated by tumor cells.

As mentioned above, the cellular inflammatory infiltrate surrounding BCCs, largely consists of $\mathrm{CD} 4+/ \mathrm{T}$-helper cells. This predominance of Th-cells over Tccells is an interesting observation, since Tc-and NK-cells are the effector cells in major histocompatibility complex (MHC)-restricted and non-MHC-restricted cellular cytotoxicity, respectively. Especially, these cytotoxic reacrions are thought to be important in the elimination of tumor cells. The mechanism by which Thcells mediate tumor regression remains unknown.

Our objective of the study presented in chapter 3 was to study the expression of granzyme B (grB) by cells present in immune infiltrates surrounding BCC, as an indicator of cytolytic activity against the tumor.

The presence of characteristic granules in the cytoplasm of cyrotoxic $T$ cells and natural killer cells correlates with activation and subsequent cytolytic potential of these cells in witro. These cytoplasmic granules contain a pore-forming protein, perforin, and several homologous serine proteinases called granzymes. The action of granzymes results in the apoptotic death of the target cell.

We investigated the expression of $\mathrm{grB}$ in 10 cases of $\mathrm{BCC}$, of which 8 were uthtreated and 2 had been treated once with intrallesional interferon- $\alpha 2 b$.

Despite the presence of significant numbers of $\mathrm{CD} 3+$ and $\mathrm{CD} 8+\mathrm{T}$ cells, there was a striking scarcity of grB-positive cells in peritumoral $\mathrm{BCC}$ areas.

The small number of cells in the infiltrate that stained for grB appeared to be $\mathrm{NK}$ cells.

In the two cases of $B C C$ treated with IFN- $\alpha 2 b$, the number of grB-positive $\mathrm{NK}$ cells in periwascular areas appeared to be increased. 
In contrast, the number of grB-positive $\mathrm{Tc}$-cells in squamous cell carcinoma $(n=5)$, melanoma $(n=4)$, and seborrhoeic keratosis $(n=3)$, was clearly increased compared to BCC.

To the best of our knowledge, our study represented the first report on expression of granzymes in immune infiltrates of human skin cancer. Recently, two new studies concerning perforin and granzymes were published. Deng et al studied perforin-expressing T cells in $40 \mathrm{BCCs}^{4}$ Only in ten specimens, very small numbers of perforin-positive cells were detected. Shimizu et al showed CD8+ infiltrating cells to contain grB in lichen planus. ${ }^{5}$ They suggested that these CD $8+\mathrm{T}$ cells. induce apoptosis of keratinocytes, resulting in the typical colloid bodies.

Besides the release of perforin and granzymes, cytotoxic $T$ lymphocytes also are able to kill target cells by surface interaction between Fas ligand and Fas. This is a fascinating new field of research, especially since failure of BCC tumor cells to express the Fas antigen has been reported, thereby avoiding $T$ cell killing by Fas ligand bearing cytotoxic T cells. ${ }^{6}$

In summary:

1) the resting state of peritumoral endothelial cells, 2) the absence of adhesion molecules on BCC tumor cells, and 3) the lack of grB expression of peritumoral Tc-cells, plead against a role of a specific anti-tumor response in BCC.

One could speculate that this is caused by an insufficient number of adequately activated $T$ lymphocytes (with their corresponding cytokine profile), responding to a specific tumor-antigen stimulation.

BCCs are typically slow growing tumors, often taking months to years to reach significant proportions. Several explanations for this clinical behaviour have been proposed: 1) prolongation of the S-(DNA synthesis) phase of the cell cycle in tumor cells; 2) a small proliferation fraction in the tumor; 3) tumor regression in response to host immune factors; 4) prominent cell death by the phenomenon of apoptosis.

Option number three, tumor regression in response to host immune factors is already discussed abowe.

We will now focus on the critical balance between cell proliferation and cell death. In chapter 4 , we investigated the expression of $b c t-2$ in BCC and also in SCC of the skin. The proto-oncogen $b c t-2$ encodes an inner mitochondrial membrane protein which shows a functional role of blocking programmed cell death, referred to as apoptosis. The protein is expressed in basal cells in normal human epithelium, but not in more superficial differentiated cells. It has been suggested that this pattern of expression assists survival of stem cells while preventing overaccumulation of differentiated cells.

I.mmunohistochemical localization using a monoclonal anti-bcl-2 antibody revealed positive $b c l-2$ expression of all $B C C s$ ( 15 patients). SCC's failed to express 
Chapter \& General discussion and summary

bcl-2 (5 parients). The positive bol-2 staining of BCC tumor cells supports the hypothesis that $\mathrm{BCC}$ originate from the basal layer of the epidermis.

The prominent $b c-2$ expression of $\mathrm{BCC}$ tumor cells also suggests that inhibition of programmed cell death occurs, and would argue against the suggestion that prominent cell death in $\mathrm{BCC}$ accounts for their typically slow growth rate.

It should be realized, however, that apoptosis is a complex process, in which several molecules besides $b c t-2$ are involved. This issue is further discussed in the following section.

To elucidate the combined role of apoptosis and proliferation in $\mathrm{BCC}_{2}$ we analyzed 6 cases of BCC in a pilot study (unpublished data). For the detection of apoptosis we used the terminal deoxynucleotidyl transferase (TdT)-mediated digoxigenin-dUTP nick end labeling (TUNEL) assay, wich is based on the detection of the 3'-OH nicks produced by apoptotic DNA fragmentation. Proliferation was measured by staining with Ki-67, a monoclonal mouse anti-human antibody which reacts to a nuclear antigen present in all phases of the cell cycle except for the $\mathrm{G}_{0}$ phase. In general, we observed very low percentages of TUNEL positive cells with a mean of $0.17 \%$ positive tumor cells. The mean proliferation index was $6.15 \%$. Combining these two results, it appears that BCCs show a low proliferation index, in combination with a low apoptotic index, i.e., a low cell turnover rate. These results were supported by several other authors. ${ }^{7,8}$ Moreover, in our group of $6 \mathrm{BCCs}$, we observed $\mathrm{Ki}-67$ reactivity especially restricted to the nuclei of three to five rows of peripheral cells localized at the base of the tumor nests. Unfortunately, this is a cumor area which often remains behind in the case of incomplete excision.

In history, the relationship berween life and death already has challenged many philosophers, poets, and theologians. It is now a subject of special interest to cell and molecular biologists as well.

For example, the wild type $p 53$ gene is located at chromosome $17 \mathrm{p}$ and functions as a tumor suppressor gene by acting like a brake on tumor growth to allow optimal repair of damaged DNA. It is suggested that if this repair is not succesfull the $p 53$ gene induces apoptosis. The mutant version of $p 53$ gene is possibly enhancing the $b c l-2$ action by further impairment of apoptosis. "Interestingly, in BCC an aberrant expression of $p 53$ protein has been reported. ${ }^{10}$

David Norris stated in 1995: "I suspect that the issue of control of apoprosis induction in $\mathrm{BCC}$ is more complex than is suggested by immunostaining for bol-2 alone. ${ }^{11}$ Since then the following proteins were discovered. The protein bax is central to activation of the program of apoptosis. ${ }^{12}$ Activation of $p 53$ induces the immediate up-regulation of bax and the rapid induction of apoptosis. Bct-2, a homologue of bax, heterodimerizes in vitro with $b a x$ and decreases the induction of apoptosis by bax homodimeric complexes. Similar dimerizarion occurs between $b a x$ and $b c l-x L$, which also inhibits the formation of $b a x$ homodizers and the in- 
duction of apoptosis. Bad is a newly described homologue of bcl-2 that forms complexes with the inhibitory molecules $b c l-2$ and $b c l-x L .{ }^{13}$ By binding to the inhibitory proteins $b c l-2$ and $b c t-x, b a d$ promotes the formation of bax homodimers and promotes apoptosis. Finally, $b a k$ is the most recent proapoptotic member of the ever-expanding bol-2 gene family. Bak has been primarily found to enhance apoptotic cell death following an appropiate stimulus. Tomkova et al showed in a recent study negative bak expression in $20 \mathrm{BCCs}$ studied. ${ }^{14}$

In conclusion, the high expression of the apoptosis-suppressing protein $b c l-2$ together with the small percentage of apoptotic and actively proliferating tumor cells, may indicate that lack of apoptosis and not increased cell proliferation is an important factor in tumor expansion in BCC.

This is an interesting speculation since some authors suggest that inhibition of programmed cell death may lead to neoplastic growth at slower rates than growth induced by oncogenes that act by stimulating cell proliferation. This could possibly be a new explanation for the typical slow growth rate of $B C C{ }^{15}$

However, the role of $b a x, b c l-x$, bad and bak in BCC should be studied in the future before any firm conclusions can be drawn.

Besides the considerations concerning possible biological implications of $6 \mathrm{cl}-2$ staining of BCC tumor cells, the immunohistochemical expression of $b c l-2$ also can be used as a diagnostic marker. In chapter 5 we studied staining differences of bol-2, transforming growth factor-beta $(T G F-\beta)$, and $C D 34$ berween $B C C$ and trichoepithelioma (TE). TEs are benign tumors confined to the dermis and characterized by aggregates of neoplastic epithelial cells with limited follicular differentiation.

Both the clinical as well the histological distinction between TE and BCC can be a diagnostic dilemma, especially for the infundibulocystic type of $\mathrm{BCC}$. This distinction is important because of the consequences for subsequent patient management. BCC displays a much more agressive tumor behaviour than TE, and should be excised completely.

Recently, $b c t-2$ and $C D 34$ expression alleady had been reported to be of diagnostic help in differentiating between TE and BCC. In addition to $b c t-2$ and CD34, we selected TGF- $\beta$ (Transforming Growth Factor- $\beta$ ) because of its pleiotropic effects on cellular differentiation and growth. Seventeen cases of TE / BCC were studied and the results of the hematoxylin-eosin stained histological. sections compared with immunohistochemical analysis of consecutive sections stained with $T G F-\beta$, $b c l-2$ and $C D 34$. The combination of staining for TGF- $\beta$ and $b c l-2$ seemed to be most valuable in differentiating TE from $\mathrm{BCC}$. In general, TE displayed TGF- $\beta$ positivity combined with negative $b c t-2$ staining whereas $B C C$ demonstrated the opposite. The CD34 staining pattern was considerably less consistent. 
TGF- $\beta$ is a multifunctional regulator of both cell growth and differentiation and has been shown to inhibit the growth of epithelial cells, stimulate mesenchymal cells and promote epithelial cell differentiation.

Glick et al studied TGF- $\beta 1$ and $T G F-\beta 2$ expression in murine skin and skin tumors. ${ }^{16}$ They showed that loss of expression of TGF- $\beta$ from epidermal cells may be associated with increased proliferation and decreased apoptosis. If we extrapolate this to the human situation in BCC, loss of TGF- $\beta$ expression could be a second mechanism responsible for extended cell survival besides expression of bcl-2. Moreover, the absence of TGF- $\beta$ expression in BCC could also be correlated with the apparent failure of the tumor cells to differentiate.

One could speculate that the $b c t-2$ positive/TGF- $\beta$ negative cells in $B C C$ are responsible for the biologically more agressive tumor behaviour of these tumors, compared to the $b c t-2$ negative/ T GF- $\beta$ positive cells in TE. So, tumors with a $b c l-2$ positive/ $T G F-\beta$ negative staining pattern possibly deserve a more agressive rherapeutical approach.

In conclusion, the TGF- $\beta$ staining patrem appears to be a helpful additional marker together with $b c /-2$ in differentiating between TE and BCC. The demonstrated staining differences may relate to the distinct origin and biological behaviour of the two tumors and may therefore be of value in subsequent patient management.

$\mathrm{BCC}$ is the most common malignancy in man, predominantly found on sunexposed areas. The incidence of $\mathrm{BCC}$ is rapidly increasing worldwide. In the Netherlands (15 million inhabitants), approximately 18.000 BCCs were diagnosed in 1994 , with an expected increase of $2.700 \mathrm{BCC}$ yearly.

Most BCCs are small, slow growing, well defined lesions easily treated by various methods. On the other hand, there is also a group of aggressive BCCs characterized by extensive local invasion and disfigurement.

In chapter 6, possible risk factors, both clinically and histologically, were evaluared in a retrospective study of 72 recurrent extensive BCCs treated by Mohs' micrographic surgery (MMS). All selected cases required at least three surgical Mohs stages before complete tumor removal was achieved.

The mean preoperative tumor size in our study was $2.1 \mathrm{~cm}$. All 72 tumors except one were located in the face, of which the nasal-perinasal area was the most common site $(51 \%)$. In $33 \%$ of the cases the histologic pattern displayed a mixture of solid and infiltrative components in the same tumor, $38 \%$ demonstrated a purely nodular tumor growth, whereas $21 \%$ was of the infiltrative type.

Besides the documented aggressiveness of the morpheaform type BCC, we also demonstrated extensive tumor growth of both nodular and nodular-infiltrative 
type BCC. Especially the perinasal area was characterized by extensive vertical tumor expansion of the nodular/nodular-infiltrative tumor type.

In chapter 7 , guidelines for surgical margins for excision of primary and recurrent BCCs were formulated on the basis of a retrospecrive study of 309 tumors treated by MMS. In our group of primary BCCs selected for high-risk areas, large tumor size and/or infiltrative histologic subtype, a minimum margin of $6 \mathrm{~mm}$ was necessary for complete removal of the tumor in more than $85 \%$ of the cases. The group of recurrent $\mathrm{BCC}$ required margins of at least $10 \mathrm{~mm}$ to achieve a comparable tumor clearance.

Previous treatment (recurrent tumors) and increasing tumor diameter (larger than $2 \mathrm{~cm}$ ), proved to be the two most important risk factors correlated with extensive subclinical tumor expansion.

First we will discuss reasonable cure rates, and how many BCCs require MMS. In this thesis surgical margins were calculated to achiewe cure rates of $85 \%$. Of course there will be a progressive improvement in cure rates as one takes wider and wider margins. If we took 15 -to $30 \mathrm{~mm}$ margins with $\mathrm{BCC}$, the cure rate would be nearly $100 \%$, but we do not believe that the subsequent morbidity would justify such an agressive approach. Because of the asymmetry of subclinical tumor extensions, whose precise location cannot be predicted, a comprehensive amount of normal tissue is always sacrified when margins of this extent are taken. We believe that it might be reasonable to aim for a $85 \%$ to $90 \%$ cure rate of $\mathrm{BCC}$. Surgeons getting a $99 \%$ cure rate for $\mathrm{BCC}$ are simply cutting out too much.

Overall, the percentage of nonmelanoma skin cancer treated by MMS amounts $30 \%$ in the United States. About $5 \%$ of Mohs surgeons believe that all BCCs require MMS, but most would agree that this is an excessive use of resources. ${ }^{17}$ In the Netherlands, MMS is quite controversial. Currently, only $1.6 \%$ of all BCCs are treated by MMS. Most of the criticism probably is based on the fact that people are not well informed. It has been said that "in its wonderful conceptual simplicity, MMS evokes a copying response from nearly every cutaneous surgeon who witnesses it" ${ }^{18}$ Arguments of opponents of the MMS procedure are the following; time consuming, expensive and surgical overutilization. However, MMS can be an effective use of physician time, depending on the infrastructure of your practice. With MMS and fresh-frozen tissue analysis it is possible to schedule four patients for MMS in the morning, and routinely all procedures, including reconstruction, are completed by afternoon. Miller et al, emphasizes that MMS is not only cost-effective but also usually less expensive than other types of therapy. ${ }^{19} \mathrm{Fi}$ nally, a lot of clermatologists comment that Mohs surgeons use a bazooka to "cure" a flea. Yet, because some skin cancers have invisible extensions, huge surgical defects are sometimes necessary, even when the clinically apparent lesion may have been small. In orher words, one of the reasons for a high cure rate with MMS, besides the meticulous histologic evaluation of margins, is the simple fact that 
Chapter 8 General distussion and stmmary

Mohs surgeons make bigger holes than the average dermatologist. Of course, some of these big holes are the consequence of previous inadequate treatment by orhers. In our opinion, MMS is the preferred technique for treatment of high risk BCCs as described in chapter 6 and 7 , because of the routine methodic accuracy for evaluation $100 \%$ of the surgical margins of the specimen, the subsequent high rate of oncologic cure, and the tissue sparing quality of the procedure. Since the incidence of BCCs is rising, hospitals in the Netherlands should provide more MMS settings in order to manage the selected difficult cases.

Another point of discussion concerns the management of tumor-positive surgical margins. Consequently, even when performing the recommended wide margins as suggested in our study, still 15\% of the cases will be excised incompletely. Bieley et al, reviewed 78 tumors treated by MMS because of margin involvement after primary excision of $\mathrm{BCC}$ to detect the presence or absence of residual tumor. ${ }^{20}$ Residual tumor was found in $55 \%$ of the cases as defined by the need for two or more stages of MMS to achieve a tumor-free plane. Reporred recurrence rates for incompletely excised $\mathrm{BCCs}$ vary between $33 \%-39 \% .^{21}$ Because of these figures, some authors adwocate a conservative policy of close observation for clinical recurrence. One study even concluded that it was cost-effective to wait and see if a recurrence appears. ${ }^{22}$ Others believe in a selective retrearing approach. They feel that features like anatomic location and histologic subtype should determine if further surgery is necessary or not. In this thesis, we want to state that diseasepositive surgical margins should not be ignored. With a likelihood of rumor recurrence ranging from 33\%-39\%, wait and see is unacceptable, and therefore only in very limited situations should watchful waiting be encouraged. As Salasche stated, "leaving tumor behind expectantly is a mix of wishful thinking and Russian roulette". ${ }^{23}$ Patients do not always return for follow up, which leads to delays in diagnosis, and when recurrences do develop, they are often deep and destructive.

\section{References}

1. Taylor RS, Griffiths CEM, Brown MD, er al. Consuiturive albsence and interferon- $\gamma$-induced expression of adhesion molecules in basal cell carcinoma. I Arn Acad Dermatol 1990;22:721-6.

2. Markey $\mathrm{AC}$, Churchill LJ, Allen MH, er al. Activation and inducer subser phenotype of the lymphocycic infiltrate around epidermally derived tumors. I Am Acad Dermatol 1990;23:214-20.

3. Yamamura M, Modlin RL, Ohmen JD, et al. Local expression of anti-inflammatory cyrokines in cancer. I Clin Invest 1993;21:1005-10.

4. Deng JS, Fajo LD, Kim B, et al. Cytotoxic T cells in basal cell carcinomas of skin. Am J Dermatopathol 1998;20:143-6. 
5. Shimizu $M$, Higaki $Y$, Higaki $M$, et al. The role of granzyme B-expressing CD8. posinve T cells in apoprosis of theratinocytes in lichen planus. Arch Dermatol Res $1997 ; 289: 527-32$.

6. Oishi M, Macda K. Sugyama S. Distribution of apoptosis-mediating Fas antigen in human skin and effects of anti- Fas monoclonal antibody on human epidermal keratinocyte squanous cell carcinoma cell lines. Arch Dermatol Res 1994:286:396-407.

7. Barrett: TL, Smith KJ, Hodge JJ, er al. Immunohistochemical nuclear staining for p53, $\mathrm{PNA}$ and $\mathrm{Ki}-67$ in different histologic variants of basal cell carcinoma. I Am Acad Dermatol 1997;37:430-7.

8. Mori $\mathrm{O}$, Hachisuka $\mathrm{H}$, Morita $\mathrm{M}$, et al. Apoptosis identified with DNA fragmencation in basal cell carcinomas. Arch Dermatol Res 1996;288:258-61.

9. Marx J. Cell death studies yield cancer clues. Science 1993;259:760-1.

10. Rady $P$, Scinicariello $F$, Wagner RF, et al. p53 mutations in basal cell carcinomas. Cancer Research 1992:52:3804-6.

11. Nornis DA. Differential control of cell death in the skin. Arch Dermatol 1995;131: 945-8.

12. Miyashita $T$, Reed $\pi C$. Tumor suppressor $p 53$ is a direct transcriptional activator of the human bax gene. Cell 1995;80:293-9.

13. Yang E, Jocke IJ, Boise LH, er a.. Bad, a heterodimeric partner for bcl-xL and bcl-2, displaces bax and promotes cell dearh. Cell 1995;80:205-11.

14. Tomkova $H_{3}$ Fujimoto W, Arata $\mathrm{J}$. Expression of bct-2 antagonist bak in inflammatory and neoplastic skin diseases. Br J Dermatol 1997:137:703-8.

15. Pezzella F, Turley H, Kuzu I, et al, Bcl-2 protein in non-small-cell lung carcinoma. N Engl J Med 1993;329:690-4.

16. Glick $A B$, Kulkarni $A B$, Tennenbaum $T$, et al. Loss of expression of transforming growth factor $\beta$ in skin and skin tumors is associated with hyperproliferation and a high risk for malignant conversion. Proc Nat Acad Sci 1993;90:6067-80.

17. McGillis $S \mathrm{~T}$, Whecland $\mathrm{RG}$, Sebbeu JE. Current issues in the performance of Mohs micrographic surgery. I Dermatol Surg Oncol 1991;17:681-4.

18. Braun M. Being certain the cancer is out. I Dermatol Surg Oncol 1987; 13:1058-60.

19. Miller PK, Roenigk RK, Brodland DG, et al. Cutaneous micrographic surgery: Mohs procedure. Mayo Clin Proc 1992;67:971-80.

20. Bieley HC, Kirsner RS, Reyes BA, et al. The use of Mohs micrographic surgery for determination of residual tumor in incompletely excised basal cell carcinoma. J Am Acad Dermatol 1992;26:754-6.

21. Susman LAE, Liggins DF. Incomplete excised basal cell carcinoma: a management dilemma? Aust N Z J Surg 1996;66:276-8.

22. Liu F, Malii E, Warde $\mathbb{P}$, er al. A management approach to incompletely excised basal cell carcinoma of the skin. Int I Radiat Oncol Biol Phys 1991;20:423-8.

23. Salasche SJ. Comment. In: Yearbook of dermarologic surgery. St Louis: CV Mosby, $1992: 86$. 


\section{Samenvatting}

Hoofdstuk 1 geeft een overzicht van de diverse aspecten van het basalcelcarcinoom (BCC) en beschrijft her doel van het onderzoek dat in dit proefschrift wordt beschreven.

Het BCC is de meest gediagnostiseerde maligniteit in Nederland, met ongeveer 29.000 nieuwe gevallen per jaar. Het veranderde zon-en reisgedrag in de laatste decennia, de vergrijzing van de bevolking en de afname van de ozonlaag spelen mogelijk een rol bij de sterke toename van de BCC-incidentie. Het BCC komt vooral voor bij de blanke oudere mens op de aan zon blootgestelde huid.

Het $\mathrm{BCC}$ is een langzaam groeiende tumor, die slechts zelden metastaseert. Wanneer het BCC echter niet afdoende behandeld wordt, kan het lokaal een destructief en invasief karakter hebben en op die wijze veel schade aanrichten, zowel in funcrionele als in cosmetische zin.

Dit proefschrift is onder te verdelen in drie verschillende onderzoekslijnen waarbij met name aandachr wordt besteec aan zowel histopathologische als ook klinische aspecten betreffende de karakterüstieke langzame groeiwijze van het BCC (1-6 mm groei per jaar).

Wij hebben onderzocht in hoeverre een specifieke cellulaire immuunrespons (hoofdstuk 2,3) en een omvangrijke celdood (hoofdstuk 4,5) mede verantwoordelijk zouden kunnen zijn voor deze langzame groeiwijze.

Tot slot zijn wij op zoek gegaan naar klinisch relevante risicofactoren van het $\mathrm{BCC}$, en hebben wij een poging ondernomen tot het opstellen van therapeutische excisiemarges (hoofdstuk 6,7).

Her doel wan het onderzoek dat in hoofdstuk 2 beschreven wordt, was om de mogelijke rol van het ontstekingsinfiltraat gelocaliseerd rondom de BCC tumorvelden op waarde te schatten. Menig auteur houdt dit ontstekinginfiltraat verantwoordelijk woor de langzame groeiwijze van het $\mathrm{BCC}$, ondanks het feit dat de ontstekingscellen vaak op afstand van de tumorvelden gelocaliseerd zijn en niet de tumor binnendringen. Voot een effectieve interactie tussen ontstekingscellen (met name $T$ cellen) en tumorcellen, is de expressie van verschillende bindingsmoleculen noodzakelijk. In dit hoofdstuk hebben wij de aanwezigheid van de bindingsmoleculen ICAM-1,VCAM-I en E-selectin op de omringende bloedvaten alsook op de tumorcellen onderzocht. Behoudens een lichte aankleuring van ICAM-I op de bloedvaten (endotheel), toonden met name de tumorcellen geen aankleuring.

Naast het onderzoeken van aan/afwezigheid van bindingsmoleculen, is het ook van belang geïnformeerd te zijn over funcrionele mogelijkheden van de ontstekingscellen. Zijn de ontstekingscellen ook in staat om de rumorcel te doden? 
In hoofdstuk 3 hebben wij de aanwezigheid van granzyme $B$ onderzocht bij T cellen. Alleen wanneer deze $T$ cellen op adequate wijze door tumorcellen zijn geactiveerd, brengen deze $\mathrm{T}$ cellen granzyme $B$ tot expressie, en zijn zij in staat de tumorcel te doden. Uit ons onderzoek kwam naar woren dat slechts enkele T cellen granzyme $B$ positief waren.

De aangetoonde afwezigheid van bindingsmoleculen op BCC tumorcellen, samen met de minimale expressie van granzyme $B$ op de omliggende $T$ cellen, pleiten niet voor een belangrijke rol van het ontstekingsinfiltraat in her $B C C$ ten aanzien van een specifieke tumorafweer.

Naast de cellulaire immuunrespons wordt ook celverlies in de worm wan geprogrammeerde celdood (apoptosis) als oorzaalk voor de langzame groeiwijze van BCCs genoemd. Tumorgroei weerspiegelt een verstoring van her evenwicht tussen cellanmaak en celafbraak. In voorafgaande studies was de aandacht met name gericht op toename van celaanmaak (proliferatie). Momenteel gaat de interesse in de wereldliteratuur echter vooral uit naar celaccumulatie ten gevolge van verminderde celdood. In hoofdstuk 4 hebben wij de anwezigheid wan bcl-2 onderzocht in BCC. $B c t-2$ is een oncogen dat cellen beschermt tegen geprogrammeerde celdood. Dit oncogen komt onder andere tot expressie in de basale cellen van de opperhuid. In de BCCs door ons onderzocht werd een duidelijke positiviteit voor bct-2 gevonden. Daarnaast bleek slechts $6.15 \%$ van de tumorcellen proliferatief actief te zijn (Ki-67 kleuring). Deze resultaten wijzen er mogelijk op dat de groei van het BCC met name wordt veroorzaakt door verminderde celdood en niet als gevolg van celproliferatie. Dit is van belang omdat tumorgroei als gevolg van verminderde celdood geassocieerd zou zijn met een minder agressief tumorgedrag.

In hoofdstuk 5 blijkt $b c-2$ samen met $T G F-\beta$ wan diagnostische waarde te zijn in het onderscheid tussen BCC en trichoepithelioma. Beide huidtumoren zijn vaak op klinische gronden niet te differentiëren echter het BCC is een kwaadaardige tumor terwijl het trichoepithelioom een goedaardige groeiwijze vertoont.

In hoofdstuk 6 worden mogelijke risicofactoren van het BCC beschreven. Uit onze patiëntenpopulatie die werd behandeld door middel van Mohs' micrografische chirurgie werden die tumoren geselecteerd waarbij sprake was van een recidief na eerdere behandeling, en waarbij tenminste drie Mohs-ronden noodzakelijk waren voordat het operatiegebied als tumorvrij werd afgegeven. De essentic van Mohs' micrografische chirurgie bestaat uit een goede grafische voorstelling van de tumorlokalisatie en her laagsgewijs excideren wan de tumor. Van iedere Mohs snede wordt het gehele resectievlak, door middel van horizontale vriescoupes, gecontroleerd. Her basisprincipe is maximale curatie bij minimale weefselbeschadiging. Belangrijkste risicofactoren waren: 1) grootte van de tumor, met name groter dan $2 \mathrm{~cm}, 2)$ lokalisatie, waarbij met name de tumoren gelokaliseerd ter hoogte van de nasolabiaalplooi gekenmerkt werden door uitgebreide verticale diepte-groei, en 3) 
histologische groeiwijze, waarbij naast de sprieterige groeiwijze, ook bij het nodulaire type uitgebreide subklinische tumorgroei werd waargenomen.

In hoofdstuk 7 worden richtlijnen geformuleerd betreffende excisie-marges voor primaire- en recidief $\mathrm{BCCs}$, op basis van een retrospectieve studie van $309 \mathrm{BCCs}$ door ons behandeld door middel van Mohs' micrografische chirurgie. Bij de groep primaire $\mathrm{BCCs}$, door ons geselecteend voor Mohs' micrografische chirurgie in verband met grootte van de tumor ( $>2 \mathrm{~cm}$ ), sprieterige histologische groeiwijze en/of lokalisatie in het centrum van het gelaat, werd een minimale excisie-marge van 6 $\mathrm{mm}$ berekend, om een radicaliteitspercentage van $85 \%$ te bereiken. Bij de groep van recidief tumoren betrof dit $10 \mathrm{~mm}$.

Tot slot kan geconcludeerd worden dat bij deze geselecteerde groep BCCs met deze subklinische uitbreiding, behandeling door middel van Mohs' micrografische chirurgie de voorkeur verdient. 



\section{Dankwoord}

Alleen nog het dankwoord en dan is dit proefschrift echt af? Het schrijven van een dankwoord is misschien wel het meest persoonlijke en tevens het minst gecensureerde onderdeel van een proefschrift. Kortom de "finale" uitdaging.

Het begon allemaal in het voorjaar van 1990, toen R-tF.H.J. Hulsmans Jesje en mij in Lesotho een brief stuurde mer de heugelijke mededeling dar hij mijn plaats als AGNIO bij prof.dr.W.J.B.M. wan de Staak tijdens het kerstdiner had zekergesteld. Beste Rabert, bedankt voor het in mij gestelde vertrouwen, en dat je aan de wieg stond van mijn wetenschappelijke-en dermatologische carrière.

Ook prof.dr.J.W.Arends, mijn "medempromotor", stond destijds al aan dezelfde wieg. Beste Jan-Willem, bedankt voor al je positieve aansporingen gedurende de beginfase, je geduld (slechts 8 jaar) en je snelle constructieve correcties van mijn teksten.

Een speciaal woord van dank voor Peter Bessems, Werner Habets en Joop Lambers voor het in de steigers zetten van dit proefschrift.

De laatste persoon die ik uit deze beginperiode wil aanhalen is dr.J.C.J.M. Veraart. Beste Joep, ik wil jou bedanken voor de morele steun en vriendschap in al die jaren dat wij samen de research-kar van de vakgroep Dermatologie hebben getrokken. In 1992 was er bij de konst van prof.dr.H.A.M.Neumann, mijn promoror, duidelijk sprake van een nieuwe frisse wind (windkrachr 10). Zo moest ik éénmaal per week de worderingen van mijn proefschrift op zijn kamer rapporteren! Beste Martino, ik bewonder je enthousiasme, je positivisme, je gastrrijheid samen met Julia en wil je hierbij danken voor de begeleiding bij de torstandkoming van dit proefschrifu. Door jouw stuwende voortvarendheid om mij destijds tot dermato-chirurg in spé te bombarderen werd tevens het wragstuk van dir boekje cen stuk helderder.

Dan mijn co-promotor, dr. R. Hoekzema. Beste Rick, bedankt voor je ongecompliceerde Amsterdamse gezelligheid, je probleemoplossend vermogen en her vele redigeren van mijn artikelen.

Prof.dr.J.J.Manni, dr.A.M.Duijuestijn, dr.V.Noordhoek Hegt, prof.dr. F.C.S.Ramaekers en prof.dr. B.J. Vermeer wil ik bedanken woor hun bereidlueid om deel uit te maken wan mijn beoordelingscommissie en voor de boeiende uurtjes samen doorgebracht.

Margriet en Annick, heel veel dank woor het steeds weer geduldig uitleggen van verdunningsreeksen, her "lenen" van stock-solutions en de gastvrijheid en gezelligheid op het laboratorium.

Het was Koos Sanders die de fundamenten legde voor het $b c l-2$ verhaal, beste Koos mijn dank hiervoor. 
Dr.R.C.Beljatards, beste Rob, dankzij jou heeft mijn eerste geesteskindje (adhesiemoleculen) toch nog her levenslicht mogen aanschouwen. Je was voor mij absoluut de juiste man op de juiste plaats, en ik dank je dan ook heel hartelijk voor je onmisbare steun.

Dr.P.C. Wever, beste Peter, ook jij hebt met jouw granzymen een zeer belangrijke nieuwe impuls aan dir proefschrift gegeven. Geheel belangenloos, en mer vol enthousiasme heefr jouw inbreng geleid tot hoofdstuk 3.

Leonite Majoie, Angela van Baardwijk en Frank Gruintjens, heel veel dank voor het monnikenwerk door jullie verricht en de prettige samenwerking.

Dan ga ik over tor mijn Mohs-periode. Ik dank dr.A.Picoto, Mohs chirurg te Lissabon. Dear. Antonio, thank you very much for your hospitaliry and for the fact that you taught me all about Mohs' micrographic surgery.

Ik dank mijn "eigen" Mohs wiever, Janet Ross, Enny Beverdam, Renate Brandsen, Gertrutu Krekels, Katja Ongenae en Judich Ostertag voor hun operationele inzet en daardoor wezenlijke input in dit proefschrift.

Als ik het dan ower inzer en productie heb, dan wordt her nu hoog tijd om stil te staan bij de duizenden vriescoupes gesneden door Sjaak, Ismène en Miriam. Ik dank jullie heel hartelijk voor dit stukje vakmanschap.

Ook veel dank aan alle pathologen die deze duizenden vriescoupes moesten beoordelen. In het bijzonder wil ik. Ton Vermeulen noemen vanwege zijn inhoudsdeskundigheid, maar vooral ook omdat zijn deur altijd voor ons open staat. Tevens wil ik Robert-Jan van Suylen bedanken dat ik steeds weer zijn microscoop mocht ontregelen voor het maken van foto's, ook al kostte mij dat een fles wijn en de toezegging dat hij in het dankwoord vermeld zou worden.

Prof.dr.M.J.A.P.Daemen, beste Mat, bedankt voor jouw aandeel in hoofdstuk 5 en de al heel lang durende prettige samenwerking.

Alle verpleegkundigen, baliepersoneel en secretaresses van de vakgroep Dermatologie wil ik via deze weg oprecht bedanken voor hun inzer en positieve uitstraling. Met name Irene wil ik bedanken, mijn klankbord in goede maar ook in slechte tijden.

Stafleden en arts-assistenten dank ik voor al het werk dat ze mij uit handen hebben genomen en ieder voor hun persoonlijke aandeel in het creëren van een inspirerende en prettige werksfeer.

Dr.P.H.A.Eerdmans, beste Pedro, zonder jouw steun zat ik nu nog steeds achter mijn antieke type-machine in plaats van achter mijn computer. Bedankt voor je back-up op velerlei gebied.

Lieve Gertrutud en Enny, jullie zijn niet voor niets mijn paranimfen. We hebben samen heel wat snij-uurtjes doorgebracht en ik verheug mij op de dag dat jullie mij ter zijdle willen zitten. Ik hoop nog heel lang te mogen genieten wan jullie professionele wijsheid, maar vooral ook van jullie vriendschap. 
Last but certainly not least, $P a$ en $M a$, Dymphna, Veronique en Tow, Marielle en Walter, Birgitte, Paud, Marion, Joost (mr Though Guy), en natuurlijk Jesje, Emily en Marije, jullie morele steun tijdens de afgelopen jaren is niet op papier samen te watten. Iech haw vaan uuch!

Wat mij nu rest is de aan Jesje toegezegde grotere rol in het huishouden (in de breedste zin van het woord...), of misschien toch maar golfen? 



\section{Curriculum Vitae}

Marc Verhaegh werd geboren op 19 april 1962 te Groningen. Zijn Atheneum- $\beta$ opleiding volgde hij aan het Jeanne d'Arc lyceum te Maastricht, waar in 1982 her diploma werd behaald.

In 1983 begon hij aan de Rijksuniversireit Limburg zijn studie Geneeskunde.

Het doctoraal examen werd afgelegd in 1987.

Tijdens zijn studie Geneeskunde was hij studentlid van de onderwijscommissie, bestuurslid van de Nieuwe Studenten Vertegenwoordiging Rijksuniversiteir Limburg, studentlid van de Stichting Wetenschappelijke Opleiding Medische Studenten en lid van de commissie de Blauwe Spiraal.

Verder vervulde hij gedurende twee jaar een student-assistenschap bij de vakgroep Farmacologie (hoofd: Prof.dr.H.A.J.Struyker Boudier) en verrichtte hij o.a. onderzoek naar het vaso-actieve effect van Plarelet Activating Factor op de thoracale arta van normotensieve ratten.

In augustus 1987 onderzocht hij het werkingsmechanisme van Pinacidil, een nieuw ontwikkelde vasodilatator met een klinische antihypertensieve werking, aan de vakgroep Biofysica te Aarhus, Denemarken.

Vanaf september 1989 tot februari 1990 was hij werkzaam in het St. James Mission Hospital te Mantsonyane, Lesotho, waar hij o.a. onderzoek verrichtte naar de drinkwaterkwaliteit.

In maart 1990 werd het arts-examen afgelegd.

Vanaf april 1990 is hij werkzaam op de afdeling Dermatologie van het Academisch Ziekenhuis Maastricht. Eerst als AGNIO en vanaf november 1993 als AGIO (opleider: Prof.dr.H.A.M.Neumann).

Eind 1992 doorliep hij gedurende twee maanden een "Mohs"-stage bij Dr. Antonio Picoto te Lissabon, Portugal.

$\mathrm{Na}$ zijn registratie als dermato-veneroloog op 1 mei. 1997 is hij als staflid binnen dezelfde vakgroep werkzaam, met als aandachtsgebieden de dermato-oncologie en dermato-chirurgie.

Met ingang van juni 1998 is hij aangesteld als chef de policlinique.

Hij is getrouwd met Jesje Schalm, oefentherapeut-Mensendieck, en vader van Emily en Marije. 



\section{List of abbreviations}

\begin{tabular}{|c|c|}
\hline$A G$ & : agressive growth \\
\hline $\mathrm{BCC}$ & : basal cell carcinoma \\
\hline BCL-2 & : B-cell leukemia/lymphoma-2 \\
\hline CLA & : cutaneous lymphocyte-associated antigen \\
\hline $\operatorname{grB}$ & : granzyme B \\
\hline HLA & : human lymphocyte antigen \\
\hline ICAM & : intercellular adhesion molecule \\
\hline IFN & : interferon \\
\hline IL & : interleukin \\
\hline LFA & : lymphocyte function-associated antigen \\
\hline MMS & : Mohs' micrographic surgery \\
\hline NBCCS & : nevoid basal cell carcinoma syndrome \\
\hline NK & : natural killer \\
\hline SCC & : squamous cell carcinoma \\
\hline SK & : seborrhoeic keratosis \\
\hline TE & : trichoepithelioma \\
\hline TGF & : transforming growth factor \\
\hline TNF & tumor necrosis factor \\
\hline TUNEL & $\begin{array}{l}\text { terminal deoxynucleotidyl transferase-mediated } \\
\text { dUTP-biotin nick end-labeling }\end{array}$ \\
\hline UV & : ultraviolet \\
\hline VCAM & : vascular cell adhesion molecule \\
\hline VLA & : very late antigen \\
\hline
\end{tabular}

